\title{
A BIBLIOTECA VIRTUAL DO ESTUDANTE BRASILEIRO DA ESCOLA DO FUTURO DA UNIVERSIDADE DE SÃO PAULO: UM ESTUDO DA SUA ESTRUTURA E DE SEUS USUÁRIOS
}

\author{
Dissertação apresentada na Pós- \\ Graduação da Escola de \\ Comunicações e Artes da \\ Universidade de São Paulo, para \\ obtenção do título de Mestre \\ em Ciências da Comunicação
}

Orientador: Prof. Dr. Fredric Michael Litto

\section{UNIVERSIDADE DE SÃO PAULO}

São Paulo

2002 
"A afinidade existe, Mas não é algo que possamos identificar. Reluz antes do conhecimento, Irradia durante o relacionamento E permanece a prova dos ventos." Sérgio Emílio

Dedico este trabalho a minha família que sempre está Presente em todos os momentos mais importantes da Minha vida, ao meu orientador Prof. Fredric Michael Litto, as minhas amigas Beatriz Rizek e Maria Del Carmen Pólo e um agradecimento especial a equipe da Bibivirt que colaborou sempre para aprimorar os Resultados deste estudo. 


\section{Sumário}

Resumo 5

Abstract 8

Capítulo 1 - Primeiros Passos

1. Introdução 12

1.1 Estímulo inicial

1.2 Revisão de literatura e histórico do problema

1.2.1 Uma nova sociedade $\quad 15$

1.2.2 A evolução da sociedade da informação no Brasil 18

1.2.3 A Internet na Educação 19

1.2.4 Das bibliotecas presenciais às virtuais $\quad 22$

1.2.5 A mudança de paradigma 25

1.2.6 Nomenclatura 27

1.2.7 O contexto social brasileiro 30

1.2.8 A Biblioteca Virtual do Estudante Brasileiro 32

1.3 Objetivos das pesquisa

\section{Capítulo 2 - Metodologia da pesquisa}

2.1 Justificativa $\quad 40$

2.2 Metodologias relacionadas 43

2.2.1 O modelo ACTIONS 43

2.2.2 A abordagem Sense-Making $\quad 45$

2.3 Conteúdo e forma do projeto 52

2.4 Estrutura do questionário 53

2.4.1 Acesso 53

2.4.2 Custos $\quad 55$

2.4.3 Funções de aprendizagem $\quad 55$

2.4.4 Interatividade 58

2.4.5 Assuntos organizacionais $\quad 65$

2.4.6 Novidade $\quad 65$

2.4.7 Velocidade $\quad 66$ 


\section{Capítulo 3 - Resultados da pesquisa}

3.1 Análise de dados 70

$\begin{array}{ll}3.2 \text { Perfil dos usuários da BIBVIRT } & 71\end{array}$

3.3 Funções de aprendizagem $\quad 87$

3.4 Análise do processo de busca de informação 93

3.5 Análise do processo de recuperação de informação 102

\section{Capítulo 4 - Considerações finais}

$\begin{array}{ll}4.1 \text { Síntese dos primeiros passos } & 111\end{array}$

4.2 Usuários da Internet no Brasil 112

4.3 A dinâmica de organização e ampliação do acervo 115

$\begin{array}{ll}4.4 \mathrm{O} \text { desafio da formação tecnológica } & 118\end{array}$

$\begin{array}{ll}4.5 \text { As oportunidades de aprendizagem } & 120\end{array}$

$\begin{array}{ll}\text { 4.6 Além das paredes da BIBVIRT } & 121\end{array}$

\section{Referências}

$\begin{array}{ll}\text { Referências bibliográficas citadas } & 125\end{array}$

$\begin{array}{lr}\text { Bibliografia geral levantada para pesquisa } & 129\end{array}$

\section{Anexos}

Anexo 1 - Sumário executivo da BIBVIRT 133

Anexo 2 - A Escola do Futuro da Universidade de São Paulo 145

Anexo 3 - Bibliotecas brasileiras na Internet 152

Anexo 4 - Pesquisa colocada no site da BIBVIRT 157

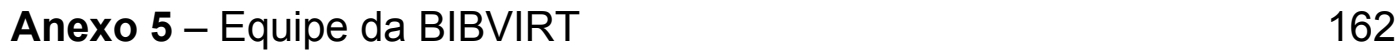




\section{Resumo}

Bibvirt, Biblioteca Virtual do Estudante Brasileiro, é uma atividade em andamento da Escola do Futuro, Laboratório de Pesquisa Interdisciplinar da Universidade de São Paulo, Brasil. O presente estudo pretende determinar se esta biblioteca virtual, iniciada em 1997 e disponível gratuitamente através da Internet (www.bibvirt.futuro.usp.br), atingiu seus objetivos originais, suas necessidades e desejos. O número reduzido de bibliotecas escolares, públicas e de livrarias em todo o território brasileiro, claramente incompatível com as necessidades de uma economia baseada no conhecimento, e os limitados fundos públicos disponíveis no passado e aparentemente no futuro, para corrigir esta situação, obriga aqueles preocupados com a futura produtividade do Brasil e sua habilidade para competir globalmente, a experimentar soluções para problemas sociais baseados nas novas tecnologias de comunicação. Apoiada inicialmente pela Fundação AT\&T e pela Secretaria do Estado e da Cultura de São Paulo, a Escola do Futuro lançou em 1997 um servidor baseado na web, contendo grande quantidade de textos, cópias recentemente digitadas de obras da Literatura Brasileira em domínio público, imagens da fauna e da flora brasileira, sons de animais nativos, de instrumentos musicais e de vozes de personagens políticos do passado, permitindo assim que os usuários utilizem e reutilizem ambos materiais áudio visual e de texto para suas necessidades acadêmicas ou de lazer. Em 2001, a média diária de usuários distintos excedia 5.000, e ao longo dos últimos três anos, a Bibvirt foi premiada nas categorias de Educação e Treinamento e Arte e Cultura.

De $1^{\circ}$ de setembro de 2000 a 25 de fevereiro de 2001, um questionário contendo 37 itens, pretendendo definir o perfil dos usuários e a natureza das satisfações e insatisfações dos mesmos, foi disponibilizado no site da Bibvirt, chegando a um total de 528 questionários respondidos, dos quais 479 foram utilizados para 0 estudo. A metodologia da pesquisa foi orientada pelo. Modelo "ACTION" desenvolvido por Anthony W. Bates (1995) e pela Abordagem "Sense-Making" desenvolvida por Brenda Derwin (1983, 1986 and 1999). 
Os resultados do questionário revelaram alguns dados inesperados: para um site planejado para estudantes de Ensino Fundamental e Médio, os atuais usuários eram, de certa forma, mais velhos: $10-13$ anos de idade: $7 \%$; $14-17$ anos: 20,9 \%; 18 -21 anos: 17 \%; 22 -25 anos: 15,1\%; 26 -29 anos: 8,4 \%; 30 -39 anos: 18,7\%; 40 para cima: $11,7 \%$. Os usuários habitantes das capitais brasileiras eram $50,8 \%$ e os habitantes do "interior" eram 49,2\%. Usuários habitantes de cidades com população acima de 1 milhão de habitantes eram $43 \%$ do total, enquanto aqueles pertencentes a cidades com mais de 500 mil habitantes e menos de 1 milhão eram 14\%, os de cidades com população entre 500mil e 100mil habitantes eram 22\%, e os usuários em cidades com menos de 100 mil habitantes eram 14\% e aqueles em cidades com menos de 10 mil habitantes eram 7\%. Estudantes de Ensino Fundamental e Médio compunham $37,8 \%$ dos usuários, enquanto que estudantes universitários representavam 23,8\% do total. Estudantes masculinos eram 50,7\% e estudantes femininas eram 49,3\%. Estudantes de escolas públicas representavam $50,7 \%$ do total e estudantes de escolas particulares representavam 49,3\%. Estudantes do Estado de São Paulo constituíram 43\% dos usuários, do estado de Minas Gerais $10 \%$, do Rio de Janeiro $8 \%$ e do Paraná $7 \%$. A renda mensal familiar reportada foi muito mais alta do que a esperada: até $\mathrm{R} \$ 300,00: 8,8 \%$; $\mathrm{R} \$ 301$ - 600,00: 8,8\%; $\mathrm{R} \$$ 601-1200,00:16,7\%; R \$1201-3000,00:17,6\%; mais de R\$20.000,00: 10,6\%. Quando questionado o local do qual os usuários acessavam à Internet, responderam: de casa: $72,1 \%$; do trabalho $17,6 \%$; da escola: 5,6\%; da casa de amigo ou parente: 3,1\%; de bibliotecas: $1,7 \% .84,4 \%$ responderam que o uso da Bibvirt era por razões de pesquisa e estudo, enquanto que $8,4 \%$ indicaram lazer e $7,2 \%$ relacionaram a trabalho. Talvez vale preocupar-se e dar futura atenção ao fato de que 57,3\% responderam que seus professores solicitaram pesquisa na web, mas não deram nenhuma orientação; $25,4 \%$ disseram que professores deram um mínimo de orientação; e somente $17,3 \%$ apresentaram que seus professores os acompanharam nas pesquisas. Quando questionado se seus professores os encorajavam a utilizar a Internet para pesquisa, houve diferentes respostas de escolas públicas e privadas: "Estavam todos os professores incentivando?": 10\% dos alunos de escolas públicas confirmaram, enquanto que $8 \%$ dos alunos de escolas privadas confirmaram esta questão; "alguns professores?': 50\% dos estudantes de escolas públicas e $44 \%$ de estudantes de escola privadas confirmaram; "nenhum 
professor"?: $40 \%$ de alunos de escolas públicas e $48 \%$ de alunos de escolas privadas confirmaram.

Em relação à questão sobre se eram capazes de encontrar com facilidade o material desejado na Bibivirt: 24,4\% responderam "sempre"; $44,1 \%$ responderam "quase sempre"; 15,7\% responderam "às vezes"; $8,4 \%$ responderam "raramente"; e 7,4\% responderam "nunca".

Se o material encontrado em bibliotecas correspondia as suas necessidades de pesquisas: $57 \%$ responderam que acharam exatamente o que procuravam; $12,1 \%$ acharam o material "muito sofisticado" e 30,9\% acharam o material "muito simples". Se eles acharam que o material que procuravam na Bibvirt poderia ser achado também em outras fontes: $36,9 \%$ disseram ser possível; $33,8 \%$ disseram que "às vezes" isto acontecia; $13,6 \%$ disseram ser difícil e 3,5\% disseram nunca ser o caso. Em ordem de importância para os usuários, o material contido na biblioteca seguia tal ordem: literatura, material didático, material para-didático, sons e imagens. Com relação à navegação na biblioteca, 90,6\% disseram não ter dificuldade, 9,4\% tiveram dificuldade; 48,5\% disseram usar o Internet Explorer 5x, enquanto que 19,2\% disseram usar o Internet Explorer 4x. Em relação a maneira pela qual eles liam o material encontrado na biblioteca, $28 \%$ liam diretamente na tela; $13,4 \%$ imprimiam o material enquanto conectados a Internet; $34,3 \%$ baixavam para posterior consulta no computador; e $23,2 \%$ carregavam para posterior impressão e leitura.

Palavras-chave: Internet, informação, comunicação, bibliotecas virtuais, bibliotecas digitais. 


\section{Abstract}

Bibvirt, the Brazilian Student's Virtual Library, is an on-going activity of research and development of the "School of the Future", interdisciplinary research laboratory of the University of São Paulo, Brazil. The present study attempted (1) to determine if this digital library, started in 1997 and available gratuitously through the Internet [www.bibvirt.futuro.usp.br], had met its original objetives, and (2) to identify the profile of its current users, their needs and desires. The reduced numbers of school libraries, public libraries and bookstores throughout Brazil, clearly incompatible with the needs of a knowledge-based economy, and the limited public funds available in the past, and apparently in the future, to rectify this situation, oblige those concerned with Brazil's future productivity and ability to compete globally, to experiment with solutions to social problems, based on the new communications technologies. Supported by initial grants from the AT\&T Foundation and the São Paulo State Secretariat for Culture, the School of the Future launched in 1997 a web-based server containing large quantities of full-text, newly-digited copies of Brazilian literature in the public domain, images of Brazilian flora and fauna, sounds of Brazilian animals, musical instruments and the voices of national political figures of the past, thereby permitting users to download and re-use for their academic needs or leisure material both textual and audiovisual. In 2001, the daily average number of discrete users exceeded 5,000; and over the last three years, the Bibvirt was awarded 5 trophies "I-Best" for excellence in content in the categories of education and training, and art and culture.

From 1 September 2000 to 25 February 2001, a questionnaire containing 37 items attempting to determine the profile of users and the nature of user satisfaction or insatisfaction, was placed on the site of the Bibvirt, drawing a total of 528 user responses, of which 479 were actually used for the study. The research methodology was oriented by Anthony W. Bates's "ACTION" approach (1995); and Brenda Derwin's “Sense-Making” approach (1983, 1986 and 1999).

The results of the survey brought some surprising results: for a site planned for primary and secondary school students, the atual users were somewhat older: 10-13 years of age: $7.0 \%$; $14-17$ years: $20.9 \%$; $18-21$ years: $17.4 \%$; $22-15$ years: $15.1 \%$; 
26-29 years: $8,4 \%$; $30-39$ years: $18.7 \%$; $40+$ years: $11.7 \%$. Those living in state capitols were $50.7 \%$ and those in the "interior" were $49.3 \%$. Users living in cities with populations over 1 million inhabitants were $43 \%$ of the total, while those in cities of over 500 thousand were $14 \%$, those in cities of between 500 thousand and 100 thousand were $22 \%$, and those in towns of less than 100 thousand were $14 \%$ and those in towns with less than 10 thousand were $7 \%$. Primary and secondary school students comprised $37.8 \%$ of users, while university students represented $23.8 \%$ of the total. Male students were $50.7 \%$ and female students $49.3 \%$. Students from public school represented $50.7 \%$ of the total, and those from private schools represented $49.3 \%$. Students from São Paulo State made up $43 \%$ of users, those from Minas Gerais 10\%, those from Rio de Janeiro $8 \%$ and those from Paraná $7 \%$. Monthly family income reported was much higher than expected: up to $\mathrm{R} \$ 300: 8,8 \%$; $\mathrm{R} \$ 301-600: 8,8 \%$; $\mathrm{R} \$ 601-1200: 16.7 \%$; $\mathrm{R} \$ 1201-3000: 17.6 \%$; $\mathrm{R} \$ 3001-6000: 8.8 \%$; $\mathrm{R} \$ 6001-10.000$ : $11.2 \%$; $R \$ 10.001-20.000: 17.6 \%$; mais de $\mathrm{R} \$ 20.000: 10.6 \%$. When asked from what location they acessed the Internet, users replied: from home $72.1 \%$; from work $17.6 \%$; from school $5.6 \%$; from a friend/relative's home $3.1 \%$; from a library $1.7 \%$. $84.4 \%$ replied that their use of Bibvirt was for study and research, while $8.4 \%$ indicated pleasure and $7.2 \%$ relation to work. Perhaps worthy of concern and further attention is the fact that $57.3 \%$ answered that their teachers required research on the web but gave no orientation; $25.4 \%$ said teachers gave minimal orientation; $17.3 \%$ indicated that their teachers accompanied their web research. When asked whether their teachers encouraged research using the Internet, there were different responses from public and private schools: "were all teachers encouraging?": $10 \%$ of public school students confirmed, while $8 \%$ of private school students confirmed this question; "some teachers?" : $50 \%$ of public school students and $44 \%$ of private school students confirmed; "no teachers?": $40 \%$ of public school students and $48 \%$ of private school students confirmed.

To the question of whether they were able to locate desired material within the library: 24.4\% answered "always"; $44.1 \%$ answered "almost always"; $15.7 \%$ answered "sometimes"; $8.4 \%$ answered "rarely"; and $7.4 \%$ answered "never". Whether or not the material found in the library corresponded to the needs of their searches: $57 \%$ responded that they found "exactly" that they sought; $12.1 \%$ found the material "very sophisticated"; and $30.9 \%$ found the material "rather simple". 
Whether they found that the material they sought in the Bibvirt could be found just as well in other sources, $36.9 \%$ said that it was possible, $33.8 \%$ said that "at times" they found this to be true, $13.6 \%$ said it was difficult, and $3.5 \%$ said it never the case. In order of importance to users, the material contained in the library was as follows: literature, didactic material, para-didactic material, sounds and images. With regard to navigation within the library, $84.4 \%$ reported having no difficulty, $8.4 \%$ had difficulty; 48.5\% reported using Internet Explorer 5x, while 19.2\% reported using Internet Explorer 4x. As regards the form in which they read the material found in the library, $28.6 \%$ read directly from the screen; $13.4 \%$ printed directly while connected to the Internet; $34.8 \%$ downloaded for posterior reading on-screen; and $23.2 \%$ downloaded for posterior printing and reading.

Keywords: Internet, information, communication, virtual librarys, digital librarys. 


\section{CAPÍTULO 1}

\section{Primeiros Passos}

"A primeira tarefa, portanto, é dizer o poço, reconhecer o aquário, tomar consciência da teia com que prendemos, aprendemos e somos presos..."

Rubem Alves 


\section{Introdução}

"No ciberespaço, como qualquer ponto é diretamente acessável a partir de qualquer outro, será cada vez maior a tendência a substituir as cópias de documentos por ligações hipertextuais ${ }^{1}$, basta que o texto exista fisicamente uma única vez na memória de um computador".

Pierre Lévy

\subsection{Estímulo Inicial}

O avanço tecnológico possibilitou o crescimento da utilização de mídias digitais numa velocidade vertiginosa, ampliando, assim, significativamente a capacidade de distribuir informação, principalmente via Internet, onde é possível acessar livros, revistas, jornais e diversos outros textos, disponíveis 24 horas por dia, em prateleiras virtuais de "bibliotecas sem paredes", situadas no ciberespaço ${ }^{2}$.

Essa possibilidade pode vir ajudar a suprir a carência de bibliotecas escolares brasileiras se forem investidos recursos que possibilitem pelo menos um computador ligado à Internet em cada uma das bibliotecas escolares. Como dito por Litto (1994) "Hoje temos dois Brasils, formados por estudantes que têm e estudantes que não têm acesso à informação. Dados estatísticos têm mostrado que somente $4 \%$ da população brasileira vive de acordo com padrões do primeiro mundo; outros $30 \%$ podem ser comparados à classe média americana; e o restante da população é na melhor das hipóteses chamada de "lutadores pela sobrevivência", sendo que a maioria da população jovem não termina a escola primária”.

\footnotetext{
1 OLIVEIRA, R. S. Minidicionário Compacto de Informática. São Paulo: Editora Rideel. 1999. Hipertexto - recurso muito usado em apresentações multimídia para tornar a leitura de textos interativa. São textos nos quais existem palavras ou símbolos que estão ligados a outros textos.

${ }^{2}$ LÉVY, P. Cibercultura. São Paulo: Editora 34. 1999. Pierre Lévy define ciberespaço como um espaço de comunicação aberto pela interconexão mundial de computadores e das memórias dos computadores. Essa definição inclui o conjunto dos sistemas de comunicação eletrônicos, na medida que transmitem informações provenientes de fontes digitais ou destinadas à digitalização.
}

${ }^{3}$ LITTO, F. Pitfalls and promises: using the Internet to Create Virtual Classrooms in the Third World. In Distance Learning and New Technologies. In: Education Proceedings of the First International Conference on Distance Education in Russia. Moscow: 5-8 July, 1994. 
Outros dados que nos mostram o baixo acesso a informações para a população brasileira são os apresentados pelo jornal "O Estado de São Paulo"4 sobre o último censo (2000), onde indicou-se que $24,9 \%$ das escolas públicas de ensino fundamental e $82,3 \%$ das escolas públicas de ensino médio têm bibliotecas. Mas, por enquanto, somente $6,7 \%$ das escolas públicas de ensino fundamental e $34,7 \%$ das escolas públicas de ensino médio têm computadores com acesso à Internet o que mostra que o acesso às informações digitais ainda é bem restrito.

Apesar da situação apresentada acima estar longe de uma resolução em curto prazo, visto que as últimas políticas públicas para prover computadores com acesso à Internet para estudantes de escolas púbicas de ensino médio terem sido inviabilizadas, temos números que nos mostram que o uso da Internet cresce rapidamente no $\mathrm{Brasil}^{5}$, tendendo a aumentar o número de acessos feitos por estudantes seja em espaços escolares, públicos ou em suas residências.

Esse é um dos fatos que me motivou a desenvolver esta pesquisa. O outro é o fato de considerar a Bibvirt como sendo o primeiro Projeto no país, criado no contexto da área educacional, com distribuição via Internet, cujo objetivo é fornecer material de qualidade em Língua Portuguesa para alunos de ensino fundamental e médio, assegurando condições de acesso indiscriminado, sejam eles estudantes de escolas públicas ou particulares.

\footnotetext{
${ }^{4}$ AVANCINI, M.; CAFARDO, R. Censo Escolar. Jornal "O Estado de São Paulo". 28/06/2001 Pg. A12 5 Não há uma pesquisa que nos mostre o número exato de internautas no Brasil. O Ibope www.eRatings.com, que representa o serviço Nielsen/NetRatings na América Latina, diz que no mês de maio de 2001, o Brasil alcançou 11,1 milhões de usuários, um aumento de quase $7 \%$ em relação ao mês de abril do mesmo ano. Já, a revista da Folha de 27/09/2001- Pg.6, diz que a Internet no Brasil continua crescendo, tendo em setembro de 200123 milhões de pessoas conectadas. Os dados apresentados pelas duas instituições são bem diferentes, não nos permitindo afirmar o número exato de usuários.

Esta diferença nos resultados da pesquisa é justificada pelo IBOPE eRatings como sendo devido a forma como é feita a coleta dos dados. Ele afirma que alguns institutos de pesquisa fazem auditorias em sites e portais filiados ou com uma amostra de alcance regional e outros, como o IBOPE eRatings que está focado no usuário e em seu comportamento na Internet, trabalham com uma amostra representativa de todo o Brasil, considerando áreas urbanas e rurais.
} 
Neste contexto, emerge o presente trabalho que consiste em um estudo para análise da identidade da Biblioteca Virtual do Estudante Brasileiro, também chamada de Bibvirt, desenvolvida e mantida pela Escola do Futuro da Universidade de São Paulo (ver anexo 2), dando maior enfoque aos limites e possibilidades em um processo de busca e recuperação de informações em seu site, tendo como hipótese que o usuário encontra certa dificuldade no desenvolvimento dessas atividades.

Neste sentido, fazer esse estudo é apresentar parâmetros relevantes para estudo de outras bibliotecas virtuais, considerando-se de extrema importância a disponibilização de informação nacional na rede, com qualidade, de fácil acesso e recuperação, voltada para a comunidade a que se destina.

A primeira fase do presente estudo, descrita neste documento, foi uma análise histórica do problema e levantamento bibliográfico com o intuito de definir os parâmetros para análise de seus usuários, bem como aproveitar de metodologias que pudessem levar à análise de processos de busca e recuperação de informações em ambientes virtuais. Num segundo momento os dados foram coletados, por meio de uma pesquisa colocada no site e, em um terceiro momento, foram feitas as tabulações, avaliação dos dados e propostas para modificações no processo de busca e recuperação de informações na Bibvirt.

$\mathrm{Na}$ análise histórica do problema e no levantamento bibliográfico, surgiram oportunidades não só de encontrar informações relevantes para compor os parâmetros de avaliação, como também foram coletadas informações sobre a formação da sociedade da informação e como as bibliotecas virtuais vieram a fazer parte deste contexto.

Com isso, antes de me deter à metodologia que foi utilizada para o estudo da Bibvirt, discorrer-se-á sobre a formação dessa nova sociedade e o surgimento das bibliotecas virtuais que contribuíram para o processo de busca e recuperação de informações na Internet. 


\subsection{Revisão de Literatura e Histórico do Problema}

\subsubsection{Uma Nova Sociedade}

A sociedade da informação que se configurou a partir da década de 60 decorre de uma revolução tecnológica cuja origem leva ao final da Segunda Guerra Mundial, e cujo complexo desenvolvimento transcorre durante toda a segunda metade do século passado, vindo a modificar, em curto prazo, muitos aspectos da vida cotidiana.

Embora muitos elementos tenham contribuído para essa transformação, dois pontos focais aparecem como determinantes para a formação da sociedade da informação: computação e comunicação, diretamente ligadas a dois objetos tecnológicos que proporcionaram, a esse crescimento, uma velocidade nunca vista: microcomputador e rede Internet, levando muitas pessoas a testemunharem uma invasão crescente, no seu cotidiano, de novas tecnologias de computação e de comunicação que causaram mudanças na quantidade, qualidade e velocidade das informações com que lidam no seu dia-a-dia. Essas transformações permitiram que elas pudessem se comunicar em tempo real, mesmo sem estarem unidas presencialmente. As informações passaram a circular rapidamente e as mudanças acompanharam este ritmo acelerado.

O surgimento de novas tecnologias de computação e comunicação fez surgir uma nova linguagem. O computador com sua capacidade de transformar experiências em informações ordenadas, armazenáveis, representáveis em diferentes formas e de fácil recuperação, possibilitando também, a transferência, a comunicação e acesso a informações oriundas de diferentes computadores, vêm contribuir com uma nova linguagem, chamada Linguagem Digital.

Toda essa transformação iniciou-se a partir de um empreendimento militar na década de 60 nos Estados Unidos, no auge da Guerra Fria. Os Estados Unidos preocupados com um possível ataque militar da União Soviética, solicitaram a ARPA - Advanced Research Projects Agency - agência do Departamento de Defesa dos Estados Unidos, que desenvolvesse uma rede de telecomunicações que não 
pudesse ser interrompida por avarias locais. Essa rede não deveria possuir uma central para não ser destruída por nenhum ataque localizado.

O projeto tomou corpo quando foi contratado Licklider ${ }^{6}$ (1960) para liderar as novas iniciativas através do IPTO - Information Processing Techniques Office - Escritório de Processamento de Informações Técnicas da agência. Um dos sonhos de Licklider era uma rede de computadores que permitisse o trabalho cooperativo em grupos, mesmo que fossem integrados por pessoas geograficamente distantes, além de permitir o compartilhamento de recursos escassos.

Em 1970 foi então criada a rede de Agências de Projetos de Pesquisa Avançada, chamada Arpanet, tendo como primeira conexão a ligação em rede de quatro universidades americanas: a Universidade da Califórnia em Los Angeles, o Instituto de Pesquisas da Universidade de Stanford, a Universidade da Califórnia em Santa Bárbara e a Universidade de Utah. Além da comunidade acadêmica, a rede original atendia também à comunidade militar americana.

Quando a Guerra Fria acabou, os militares passaram boa parte da estrutura construída para desenvolvimento da Internet às universidades norte-americanas e quem passou a custear o crescimento da rede foi a NSF (Fundação Nacional da Ciência). Em 1990, a Arpanet foi abandonada definitivamente dando lugar a um amplo e moderno sistema de comunicação entre universidades, fazendo com que o projeto de intercâmbio extrapolasse os limites dos Estados Unidos, conectando vários centros de pesquisa e estudo do mundo.

\footnotetext{
${ }^{6}$ LICKLIDER, J.C.R. Man-Computer Symbiosis, 1960. Available from Internet: <URL: http://livinginternet.com/i/ii licklider.htm > [15.12.2001]

"It seems reasonable to envision, for a time 10 or 15 years hence, a 'thinking center' that will incorporate the functions of present-day libraries together with anticipated advances in information storage and retrieval. The picture readily enlarges itself into a network of such centers, connected to one another by wide-band communication lines and to individual users by leased-wire services. In such a system, the speed of the computers would be balanced, and the cost of the gigantic memories and the sophisticated programs would be divided by the number of users."
} 
Esse intercâmbio iniciou-se a partir da criação de uma espécie de linguagem comum, um "esperanto" do mundo digital, batizado de TCP/IP (Protocolo de Controle de Transmissão/Protocolo da Internet). Mas, o que fez a Internet tornar-se realmente uma realidade foi a criação de um programa, chamado browser ou navegador, que conseguiu reproduzir textos e imagens guardados em um computador possibilitando o acesso por diversos outros computadores em lugares diferentes.

Esse programa impulsionou o desenvolvimento da WWW (World Wide Web, Teia Mundial), entretanto a sua grande popularidade veio mesmo com o programa Navigator, criado pelo visionário Marc Andreessen ${ }^{7}$, fundador da Netscape, que hoje faz parte do grupo America Online. A partir daí, a Internet passou a ser uma grande teia de informações destinada a diferentes pessoas, individualmente ou em grupos.

\subsubsection{A Evolução da Sociedade da Informação no Brasil}

A sociedade da informação no Brasil teve início antes mesmo do advento da Internet por meio do videotexto, instalado pela primeira vez em São Paulo em 15/12/1982. Como definido por Plaza ${ }^{8}$ (1984) "O videotexto é um veículo de produção de linguagem e de distribuição de informações". A diferença em relação a outros meios de comunicação da época era sua interatividade que nascia em um meio interpessoal. "O Videotexto integra, num só conjunto, as tecnologias ligadas à informação e à computação com a editoração e a disseminação da informação, além de envolver aspectos jornalísticos e de biblioteconomia. Com ele, é possível construir bancos de dados no computador facilmente acessíveis a usuários nãoespecializado" trecho da entrevista de Litto $^{9}$ (1992) para a revista Educação e Informática. Pela associação de telefone, do televisor e do computador (como banco

\footnotetext{
${ }^{7}$ GRIFFIN, S. Internet Pioneers. Chapel Hill, 2000. Available from Internet <URL:http://www.ibiblio.org/pioneers/andreesen.html > [16.12.2001]
}

"Marc Andreesen was a student and part-time assistant at the National Center for Supercomputing Applications (NCSA) at the University of Illinois when the World Wide Web began to take off. His position at NCSA allowed him to become very familiar with the Internet. Like just about everyone else who was involved with the Internet, he also became familiar with the Web."

${ }^{8}$ PLAZA,J. et. al. Comunicação e novas tecnologias. Editora Com-Arte. Escola de Comunicações e Artes. Universidade de São Paulo. S. Paulo. 1984. 59 p.

${ }^{9}$ FERREIRA, M; COSTA, M. A Escola do Futuro e as Novas Tecnologias Aplicadas à Educação. São Paulo: Revista de Educação e Informática. Fundação para o Desenvolvimento da Educação - FDE. Ano 3. N8. Pg.26.1992. 
de dados) e de um pequeno teclado, o usuário, através de uma rápida teclagem (semelhante a uma chamada telefônica), acessa os mais variados tipos de informação visual e escrita.

Logo em seguida à implantação do videotexto na cidade de São Paulo, Litto (1984) afirmou que havia espaço para o videotexto entre nós, atuando não apenas em escritórios executivos e em lugares públicos como shoppings e saguões de aeroporto, mas também em setores que atingem outras camadas menos privilegiadas da sociedade, como por exemplo, em escolas de ensino fundamental.

"O videotexto com seus muitos atributos de cores, animação de imagem e interatividade, representa uma verdadeira inovação para o ensino, reunindo as características de uma máquina para processar dados e um aparelho para fins audiovisuais. Sua presença em qualquer sala de aula seria justificável, mesmo se fosse apenas como uma fonte de informações gerais, sem uma programação especial". 10

O videotexto não chegou a ser uma ferramenta amplamente difundida, pois com a entrada da Internet no Brasil reduziu-se o número de projetos utilizando essa tecnologia. O pontapé inicial no uso da Internet no Brasil deu-se devido ao pioneirismo de algumas instituições acadêmicas e ONGs, com o apoio do Governo Federal, através do Ministério da Ciência e Tecnologia (MCT), e de vários governos estaduais, tais como os de São Paulo, Rio Grande do Sul e Rio de Janeiro.

Como se pode observar no Livro Verde ${ }^{11}$, uma primeira versão de serviços Internet com pontos em 21 estados no país, foi implantada pela Rede Nacional de Pesquisa (RNP) de 1991 a 1993, a velocidades baixas. Entre 1995 e 1996, esses serviços foram atualizados para velocidades mais altas. Paralelamente, a partir de junho de 1995, uma decisão do Governo Federal definiu as regras gerais para a disponibilização de serviços Internet para quaisquer interessados no Brasil.

\footnotetext{
${ }^{10}$ LITTO, F. at. al. Videotexto e responsabilidade social no terceiro mundo. In: Comunicação e novas tecnologias. Editora Com-Arte. Escola de Comunicações e Artes. Universidade de São Paulo. São Paulo. 1984. 59 p.
}

${ }^{11}$ TAKAHASHI, T. Sociedade da Informação no Brasil. Livro Verde. Brasília: Ministério da Ciência e Tecnologia, 2000. p.133 
Com isso, o acesso a rede cresceu rapidamente no Brasil, fazendo com que a cada ano mais pessoas façam parte da comunidade virtual, atingindo hoje por volta de 23 milhões de pessoas no Brasil, como já apresentado anteriormente, sendo 6 milhões de internautas ativos em dezembro de $2001^{12}$.

$\mathrm{Na}$ pesquisa feita pela Revista da Folha (27/09/2001- Pg.6), temos que o crescimento no número de acessos acontece tanto nas classes A/B (46\% dos integrantes destas classes sociais estão utilizando a Internet) quanto na classe $C$ (um aumento de $3 \%$ em relação a pesquisa anterior) e D/E (aumento de $2 \%$ ), justificado na reportagem como sendo devido a redução do preço das assinaturas, o surgimento de provedores gratuitos, a iniciativa de disponibilizar o acesso em escolas e locais públicos e as linhas de financiamento para a compra de computadores. Um fator não apontado na reportagem, mas que também tem contribuído para o maior acesso a rede Internet é a maior quantidade de propagandas sobre sites em outras mídias e a possibilidade de participar de pesquisas de opinião de programas esportivos, políticos e de entretenimento pela rede.

Dentre os diferentes grupos de usuários da Internet, existe um de maior interesse para essa pesquisa: os educandos. Diante dos fatos apresentados anteriormente, podemos perceber que a Internet pode vir a ser um importante instrumento educacional, pois possibilita o acesso, sem muita dificuldade, a textos, sons, imagens e vídeos por pessoas localizadas em grandes centros urbanos ou em pequenas localidades.

\subsubsection{A Internet na Educação}

Com o advento da Internet surgiram novos meios de interação, comunicação e acesso à informação de uma forma democrática, que pode potencializar o processo de ensino-aprendizagem, dependendo de como é abordada pelo educador.

\footnotetext{
${ }^{12}$ Dado retirado do site do lbope eRatings, apresentado na URL http://www.ibope.com.br/eratings/index.htm available from Internet [14.01.2002] no artigo "Internet o melhor dezembro da História" publicado em 11 de janeiro de 2002.
} 
$\mathrm{Na}$ Educação, a entrada da tecnologia e suas diferentes formas de comunicação, decorrentes desta nova linguagem, ocorrem de uma forma mais lenta do que nas outras áreas. Segundo Almeida ${ }^{13}$ (2000), existe uma resistência muito grande de parte dos educadores e instituições brasileiras em trabalhar com ela, muitas vezes devido à falta de preparo ou informações para o corpo docente.

Mas, um grande esforço tem sido feito através de programas de formação de professores organizados por diferentes instituições, na expectativa de que os professores se arrisquem a inserir os recursos tecnológicos em sua prática diária de uma forma criativa e inovadora. A formação tem acontecido por meio de oficinas desenvolvidas por diferentes centros de apoio ao professor como, por exemplo, os cursos oferecidos pela Escola do Futuro da Universidade de São Paulo (ver Anexo 2), onde os professores podem vivenciar atividades, que poderão desenvolver com seus alunos, tais como atividades por meio da comunicação e troca de experiências via e-mail, participação em listas de discussão, fóruns como também debates através de chats, em tempo real.

Outras estratégias também importantes que podem ser adotadas, pelos professores em um processo de ensino-aprendizagem, e que são abordadas na maioria dos cursos de formação para professores, são as atividades de busca de informação nos mais de dois bilhões ${ }^{14}$ de sites nacionais e internacionais de grandes empresas, instituições de ensino, museus, organizações não governamentais, revistas, jornais e bibliotecas virtuais, que possibilitam o acesso e a recuperação de informações de forma eficaz à medida que os professores forem incorporando essas estratégias em suas práticas diárias. Para orientar o processo de busca de informações de professores e alunos, a Escola do Futuro da Universidade de São Paulo está com um novo projeto chamado WebQuest (www.webquest.futuro.usp.br), onde os professores podem contar com o apoio de uma metodologia para pesquisa em ambientes virtuais.

\footnotetext{
${ }^{13}$ ALMEIDA, M. Informática e Formação de Professores. Secretaria de educação a Distância. Brasília: Ministério da Educação, Seed. 2000. 192 p.
}

${ }^{14}$ BAPTISTA, C. A dor de nunca saber o bastante. Revista Veja, São Paulo, Edição 1716, 5 de setembro de 2001. 
A utilização da Internet torna-se cada vez mais imprescindível para a pesquisa e construção do conhecimento, afirmação que encontra apoio, indiretamente, no seguinte comentário de Pierre Lévy ${ }^{15}$ sobre a importância das tecnologias da inteligência: "A inteligência ou a cognição são o resultado de redes complexas onde interagem um grande número de atores humanos, biológicos e técnicos. Não sou 'eu' que sou inteligente, mas 'eu' com o grupo humano do qual sou membro, com minha língua, com toda uma herança de métodos e tecnologias intelectuais (dentre as quais, o uso da escrita). Para citar apenas três elementos entre milhares de outros, sem o acesso às bibliotecas públicas, à prática em vários programas bastante úteis e numerosas conversas com os amigos, aquele que assina este texto não teria sido capaz de redigi-lo. Fora da coletividade, desprovido de tecnologias intelectuais, 'eu' não pensaria”.

Além do comentário de Lévy, podemos contar com um relato de experiência apresentado por Gomes e equipe ${ }^{16}$, do Prossiga, onde fala-se que:

"No Brasil existem algumas iniciativas de produção de recursos de informação como o repositório organizado pela Fundação André Tosello na área de biodiversidade contendo: $3 / 4$ da Base de Dados Tropical, do Cenargen, na área de biotecnologia, e os da Rede Nacional de Pesquisa (RNP), nas áreas de meio ambiente, educação, jornalismo, entre outros. $A$ iniciativa pioneira da RNP de produzir esses repositórios decorreu da reconhecida importância destes instrumentos para a comunidade científica e profissional".

Com a mesma finalidade de organizar as informações no ciberespaço surgem as bibliotecas virtuais com acervo próprio e links para outros sites que complementem as informações a que se destina, para grupo de usuários específicos.

A Bibvirt é uma delas, contemplando em sua programação a indicação de material para pesquisa a alunos de ensino fundamental, médio e escolas técnicas, com um variado e amplo acervo.

\footnotetext{
${ }^{15}$ LÉVY, P. As tecnologias da inteligência. O futuro do pensamento na era da informática. RJ: Ed. 34, 1993.

${ }^{16}$ GOMES, S. L. R et. al. Bibliotecas virtuais na Internet: a experiência do Prossiga Brasília: Revista Ciência da Informação. V.25, n³, 1996.
} 


\subsubsection{Das Bibliotecas Presenciais às Virtuais}

A história das bibliotecas presenciais inicia-se em Alexandria no Egito, centro cultural mundial entre os séculos III e IV d.C., onde é criada a primeira biblioteca, chamada Biblioteca de Alexandria ${ }^{17}$. Esta famosa biblioteca continha praticamente todo o saber da Antiguidade em cerca de 700 mil papiros e pergaminhos. Seu acesso era restrito, até porque a maioria da população não sabia ler.

Em 640 d.C., o califa Omar ordenou que fossem queimados todos os pergaminhos e papiros da biblioteca sob o argumento de que "os livros contêm o que está no Alcorão e são desnecessários ou contém o oposto e não devemos lê-los".

Esse fato não impediu que a história intelectual do homem, aliada à memorização, fosse marcada por constante busca no desenvolvimento dos meios de registro e de organização dos produtos de sua vida material e espiritual de existência: registros em papiros, tabuinhas de argila, pergaminhos, papéis, evoluindo para caracteres eletrônicos; organização intermediada por interfaces grafadas, manuscritas, impressas, digitais, analógicas, que refletem o sentido da obra individual ou grupal para uso coletivo.

Um dos momentos de transição mais importante na busca de novas formas de registro e organização do acervo intelectual da humanidade aconteceu no período compreendido entre 1945-1985 no qual alguns autores imaginaram a nova biblioteca como dispondo de recursos tecnológicos para fazer frente à explosão bibliográfica e favorecer, por conseguinte, o acesso à informação por parte do usuário, principalmente aqueles das áreas científicas e tecnológicas.

\footnotetext{
${ }^{17}$ Biblioteca de Alexandria. Alexandria, no Egito, reinou como centro da cultura mundial no período dos séculos III a IV d.C. Sua famosa biblioteca continha praticamente todo o saber da Antiguidade em cerca de 700 mil papiros e pergaminhos. Seu acesso era restrito, até porque a maioria da população não sabia ler. Em 640 d.C., o califa Omar ordenou que fossem queimados todos os livros da biblioteca sob o argumento de que "ou os livros contém o que está no Alcorão e são desnecessários ou contém o oposto e não devemos lê-los".
}

VENTURI, J. De Alexandria à Internet. In: Revista Educação. Set, 2001. Pg. 96. 
Vannevar Bush foi um dos pioneiros nesta área, considerado o pai da biblioteca digital. Em seu documento escrito em 1945, intitulado "As We May Think"18, imaginou uma máquina - denominada Memex - que facilitaria a disseminação da informação científica e, com o emprego dela, armazenaria, para uso posterior, toda a informação do seu interesse.

Outra contribuição importante foi dada por Albert G. Hill ${ }^{19}$ em 1951, quando propõe a idéia de uma biblioteca eletrônica para facilitar o acesso à informação por parte do pesquisador que, mediante perfis de interesses armazenados no computador, poderia receber e enviar informações relevantes às suas atividades.

Algum tempo depois, Ted Nelson ${ }^{20}$, idealizador do hipertexto, em 1965, propôs a criação de uma biblioteca eletrônica - World Publishing Repository - Project Xanadu, que fosse um grande depósito, potencialmente infinito, de todos os documentos da humanidade. Estes documentos, arquivados em uma estrutura universal de dados, poderiam apontar de modo associativo para outros documentos afins, tendo em comum sua natureza digital e hipertextual, no qual os links redefinem a fronteira entre um documento e outro. Xanadu seria um "lugar mágico da memória literária onde nada seria esquecido" Nelson (1965).

Ainda em 1965, Licklider ${ }^{21}$, seguidor das idéias de Bush, sugeriu a criação de uma biblioteca eletrônica, afirmando que o livro não era o melhor suporte para armazenamento de informações. Hoje, quando observo os diferentes suportes para armazenamento de informações, devo discordar de Licklider, pois noto o valor de cada um dos suportes como tendo uma finalidade específica e seu espaço garantido na sociedade da informação.

\footnotetext{
${ }^{18}$ BUSH, V. As we may think. The Atlantic Monthly. n. 176, p. 101-108, July 1945. Available from Internet: <URL:http://www.notredame.ac.jp/ftplib/Articles/CMC/bush45.txt> e

$<$ URL:http://www.isg.sfu.ca/ duchier/misc/bush> [01 Dec 2001]

${ }^{19}$ HILL, A. G. The storage, processing and the communication of information. In: Bibliography in an age of Science. Urbana (IL): University of Illinois Press, 1951. p. 73-90.

${ }^{20}$ NELSON, T. Xanadu. (c.a.1965). Available from Internet: <URL: http://www.xanadu.net/xanadu/>. [01 Dec 2001]

${ }^{21}$ LICKLIDER, J. C. R. Libraries of the future. Cambridge (Mass.): MIT Press, $1965.219 \mathrm{p}$.
} 
Outra pessoa que contribuiu para a criação de bibliotecas virtuais foi Parker ${ }^{22}$ prevendo que até 1975 os catálogos estariam disponíveis em linha e, em 1985, todo o acervo bibliográfico estaria armazenado em computadores. Imaginou uma máquina que teria tela e teclado, oferecendo as funções de uma biblioteca e de um jornal, com a capacidade de acessar redes de informação por meio da linha telefônica. Sua previsão ainda não representa a realidade atual. Hoje, realmente podemos acessar redes de informação por meio da linha telefônica, mas ainda está longe o dia que teremos todo o acervo bibliográfico em formato digital.

Quase quarenta anos depois de Bush, em 1984, Dowlin ${ }^{23}$ apresenta a idéia da criação de uma biblioteca eletrônica dentro da Pikes Peak Library, localizada no Colorado, na qual seria enfatizado o rápido acesso à informação por meio de sistemas de comunicação eletrônica. A biblioteca pública se transformaria em um centro de informação comunitário, coletando informações sob as mais diversas formas, criando bases de dados relativas a assuntos sociais ligados à sua clientela.

Mas, foi Larry Ellison ${ }^{24}$, chefe executivo da Oracle Corporation, nos Estados Unidos, que na apresentação do projeto Infobahn, Information Highway - Internet Informações na Estrada da Internet, no limiar do século XXI, trouxe a idéia do "todoinclusivo" e apresentou a iniciativa para desenvolvimento da primeira biblioteca virtual quando declarou:

"Os gregos antigos se esforçaram para construir uma biblioteca... e conseguiram reunir mais de 700.000 volumes na cidade de Alexandria. Segundo a tradição, todos os mercadores que passassem por lá deveriam colocar seus papiros à disposição para cópia.

... Meu sonho é criar uma Biblioteca de Alexandria dos tempos modernos."

\footnotetext{
22 PARKER, E. B. The new communication media. In: Wallia, C. S., ed. Toward century 21: technology, society and human values. New York: Basic Books, 1970.

23 DOWLIN, K. E. The electronic library: the promise and the process. New York: Neal-Schuman, 1984. 199 p. ISBN 091-8212-758.

${ }^{24}$ ELLISON, L. Interviewer: Daniel Morrow, Executive Director, The Computerworld Smithsonian Awards Program. 24 October 1995. Available from Internet <URL:

http://http://americanhistory.si.edu/csr/comphist/le1.html $>$ [15.12.2001]
} 
Fazendo esta retrospectiva, podemos perceber que da Biblioteca de Alexandria, com sua interface PINAKES (um catálogo da coleção grafado em tabletes de argila) a Infobahn com suas interfaces digitais, as ferramentas de busca de informação, com a ajuda do engenho humano que prova e comprova seu talento, sua arte, sua criatividade, sua paixão, agregam a uma rede de interfaces suas múltiplas faces.

A configuração de uma nova tecnologia intelectual propiciada pelo surgimento da Internet, da qual passam a se beneficiar milhares de instituições com seus milhões de usuários, abre um novo campo de possibilidades à cultura. Seus efeitos, inimagináveis e imprevisíveis, dependem, porém, da amigabilidade dos atores com a interface que exploram.

Há pouco tempo atrás essa questão não era um problema, pois ficava difícil imaginar que podíamos buscar informações em diferentes suportes ao mesmo tempo, a não ser indo até a biblioteca presencial mais próxima.

Hoje, a procura de dados nas enciclopédias, jornais ou microfilmes contidos em um acervo, acontece não só no presencial, mas é complementada com a possibilidade de encontrarmos este mesmo material em formato digital.

Segundo Ângelo Mandel, professor do IME (Instituto de Matemática e Estatística) no departamento de Ciências da Computação da Universidade de São Paulo, o papel tradicionalmente desempenhado pelas bibliotecas deverá ser tomado pelas bibliotecas virtuais, já que, segundo ele, a informação que antes era encontrada somente em mídia impressa, tornará cada vez mais disponível no formato digital.

\subsubsection{A Mudança de Paradigma}

Uma das primeiras coisas que mudam, quando se comparam as características de uma biblioteca presencial com uma virtual é que, graças às tecnologias das telecomunicações em rede, a localização física de documentos é irrelevante, isto é, independe de onde é armazenada.

O conceito de "lugar" torna-se secundário, tanto para quem provê informação como para quem usa a informação. A biblioteca virtual, com freqüência, aponta para as 
fontes de informação sem, necessariamente, possuir a propriedade física das mesmas. O conhecimento humano está, atualmente, disperso no ciberespaço, desdobrando-se em um tempo descontínuo.

Hoje um estudante pode encontrar uma informação no ciberespaço, sem necessariamente saber se ela está locada do lado da sua casa ou em uma cidade do outro lado do mundo. Com isso, há uma mudança de paradigma onde o foco deixa de ser o acervo e passa a ser o "acesso" e, com freqüência, a "confiabilidade" da informação.

Nesta nova perspectiva o importante é saber quem produziu a informação, o que o levou a identificar como valiosa, quais foram as formas de seleção a fim de disponibiliza-la para uso comum, como foi escolhida a forma de acesso e quem garante sua autenticidade.

O novo paradigma emerge também de uma nova forma de organização das informações chamada hipertexto, que é a possibilidade de em um texto encontramos palavras ou símbolos que remetem a outros textos, proporcionando facilidades que extrapolam o conceito tradicional de informação bibliográfica, baseada em documentos, como artigos de jornais, revistas ou livros didáticos.

Essa nova forma de organização possibilita encontrarmos um maior número de informações em diferentes mídias, fazendo com que os estudantes tenham um outro olhar para a sua pesquisa, que pode ser feita a partir de dados encontrados em páginas da Internet e em diversos outros materiais multimídia, atribuindo um outro significado.

Além do acesso às informações presentes em um desses formatos, novos recursos que dão suporte a pesquisa foram colocados à disposição dos estudantes potencializando a busca de informações por meio de trocas de experiências, tais como listas de discussão, fóruns eletrônicos, chats e trocas de informações via email. Segundo Marcondes ${ }^{25}$ (1997), "Estes recursos tanto servem de subsídio à

\footnotetext{
${ }^{25}$ MARCONDES, C. H.; GOMES, S. L. O impacto da Internet nas Bibliotecas Brasileiras. São Paulo: Revista Transinformação. Publicação Quadrimestral. V.9, n², maio/agosto. 1997.
} 
pesquisa quanto de canais de comunicação dos resultados e de garantia de primado e originalidade intelectuais dos mesmos".

\subsubsection{Nomenclatura}

Em relação à nomenclatura utilizada para identificar os serviços de informação disseminados em rede, existem vários termos contendo pontos semelhantes e diferenciados, gerando expressões diversificadas, tais como: bibliotecas digitais, bibliotecas eletrônicas, bibliotecas do futuro, bibliotecas biônicas, bibliotecas sem paredes ou bibliotecas virtuais.

Marchiori ${ }^{26}(1997)$ tem uma definição interessante para esses termos como podemos ver a seguir:

A biblioteca eletrônica é o termo que se refere ao sistema no qual os processos básicos da biblioteca são de natureza eletrônica, o que implica ampla utilização de computadores e de suas facilidades na construção de índices on-line, busca de textos completos e na recuperação e armazenagem de registros.

A biblioteca eletrônica direciona-se para ampliar o uso de computadores na armazenagem, recuperação e disponibilidade de informação, podendo envolver-se em projetos para a digitalização de livros. Haverá um uso extensivo de meios eletrônicos que ainda coexistirão com as publicações eletrônicas e será possível remeter-se ao bibliotecário e aos sistemas especialistas.

A biblioteca digital difere das demais, porque a informação que ela contém existe apenas na forma digital, podendo residir em meios diferentes de armazenagem, como as memórias eletrônicas (discos magnéticos e óticos). Desta forma, a biblioteca digital não contém livros na forma convencional e a informação pode ser acessada, em locais específicos e remotamente, por meio de redes de computadores. A grande vantagem da informação digitalizada é que ela pode ser compartilhada instantânea e facilmente, com um custo relativamente baixo.

\footnotetext{
${ }^{26}$ MARCHIORI, P. Z. Ciberteca ou biblioteca virtual: uma perspectiva de gerenciamento de recursos de informação. São Paulo: Revista Transinformação. Publicação Quadrimestral. V.9, n², maio/agosto. 1997.
} 
A biblioteca virtual é conceitualizada como um tipo de biblioteca que, para existir, depende da tecnologia da realidade virtual. Neste caso, um software próprio acoplado a um computador sofisticado reproduz o ambiente de uma biblioteca em duas ou três dimensões, criando um ambiente de total imersão e interação. É então possível, ao entrar em uma biblioteca virtual, circular entre as salas, selecionar um livro nas estantes, "tocá-lo", abri-lo e lê-lo. Obviamente, o único "lugar" onde o livro realmente existe é no computador e dentro da cabeça do leitor.

Poulter $^{27}$ (1994) nomeia este tipo de biblioteca como biblioteca de realidade virtual, deixando claro, em sua opinião, que uma biblioteca de realidade virtual não é a mesma coisa que uma biblioteca virtual, pois o conceito de "biblioteca virtual" está relacionado com o conceito de acesso, por meio de redes, a recursos de informação disponíveis em sistemas de base computadorizada, normalmente remotos, e que uma "biblioteca de realidade virtual" funciona como uma nova forma de catálogo online de acesso público, construída utilizando-se a tecnologia de realidade virtual.

Ainda segundo Poulter, a essência da biblioteca de realidade virtual exige uma aplicação de programas de computador para simular estruturas físicas de bibliotecas, ordenando os recursos de distribuição e identificação das informações que ela contém. Os dados bibliográficos podem ser acessados via uma interface virtual, amigável, que familiariza o usuário com o meio, aparecendo na tela como uma sala com estantes, na qual um usuário pode navegar e controlar o ambiente utilizando um aparelho especial, como um mouse de três dimensões, por exemplo.

Um software para realidade virtual é um visualizador e um construtor de um mundo virtual em um computador, que pode estar apenas na tela deste, ou exigir aparelhagem especial, como luvas e capacetes, no caso de 3D.

Além da nomenclatura de Marchiori e Poulter, contamos com uma outra definição para esses mesmos termos e que deve ser mencionada. Essa definição foi apresentada no I Seminário da Rede de Bibliotecas Virtuais do Prossiga, realizado no Rio de Janeiro em setembro de 1998, quando foi apresentado o trabalho

\footnotetext{
${ }^{27}$ POULTER, A. Building a browsable virtual reality library. Aslib Proceedings, v. 46, n. 6, p. 151, June 1994.
} 
"Avaliação de Metadados de Bibliotecas Virtuais e criação de um núcleo básico de terminologia: padrão Prossiga", elaborado por Lena Vânia Ribeiro Pinheiro (consultora do Prossiga), Sandra Lúcia Rebel Gomes (coordenadora do projeto "Bibliotecas Virtuais Temáticas"), Simone Alencar, Mariana Duarte e Renato de Azevedo Rezende Neto, analistas de informação integrantes da equipe do CNPq/Prossiga.

Nessa ocasião, os conceitos básicos utilizados para referência neste estudo, foram extraídos da Sociedade Americana para Ciência da Informação (ASIS - American Society for Information Science - Thesaurus, 2nd Edition - 1998) como referência a fim de contribuir com a discussão sobre os aspectos conceituais. São eles:

\section{Bibliotecas digitais}

"Bibliotecas cujos conteúdos estão originariamente em forma eletrônica e são acessados local ou remotamente por meio de redes de comunicação".

\section{Bibliotecas virtuais}

"Sistemas nos quais os recursos de informação são distribuídos via rede, independentemente de sua localização física num determinado local".

\section{Conceito de Biblioteca Virtual do Programa Prossiga.}

Biblioteca virtual é um serviço de informação especializada que reúne em único espaço virtual, informações dispersas, capturadas da Rede e de outras ambiências, que são integradas de acordo com normas, padrões, metodologias e tecnologias comuns, organizadas em forma de base de dados e disponibilizadas na Internet.

Dentre as bibliotecas virtuais nacionais existe uma que é alvo desta dissertação de mestrado, a Biblioteca Virtual do Estudante Brasileiro, também conhecida por Bibvirt.

Litto (1997), no planejamento da Bibvirt (ver o sumário executivo no Anexo 1), considerou-a como uma biblioteca virtual que tem o objetivo de fornecer material de estudo e pesquisa via Internet, com qualidade e gratuitamente para alunos de ensino fundamental e médio, de escolas públicas e privadas no Brasil. 
Se considerarmos a nomenclatura apresentada por Poulter como a correta, podemos dizer que a Bibvirt é uma biblioteca virtual, pois ele relaciona o virtual ao acesso. Mas, se considerarmos o padrão Prossiga a Bibvirt não é, stricto senso, uma biblioteca virtual, mas uma biblioteca digital, pois ela possui um acervo próprio armazenado em um dos computadores da Escola do Futuro, bem como link para outros sites, completando as informações a que se destina.

Como a Bibvirt foi criada e nomeada antes da apresentação da nomenclatura apresentada no I Seminário da Rede de Bibliotecas Virtuais do Prossiga ${ }^{28}$, vamos compreendê-la como sendo uma biblioteca virtual.

\subsubsection{O Contexto Social Brasileiro}

É reconhecido que as bibliotecas virtuais estão revolucionando a maneira como estudantes, professores, pesquisadores e cidadãos comuns estão acessando e usando a informação. A rapidez e facilidade na busca de informações fazem com que as bibliotecas virtuais sejam cada vez mais populares.

Estudo recente do Grupo de Trabalho de Bibliotecas Virtuais - GTBV, do Instituto Brasileiro de Informação em Ciência e Tecnologia - IBICIT, demonstrou que já existem 230 sites de bibliotecas brasileiras na Internet. Isto não significa, no entanto, que o acervo de todas elas possa ser lido pela Internet, pois em muitos casos ele não está digitalizado. A grande maioria contém on-line somente dados institucionais ou o catálogo da biblioteca. Trata-se apenas de bibliotecas não virtuais com catálogos digitalizados (ver anexo 3).

A Biblioteca Virtual do Estudante Brasileiro representa a possibilidade de aparecimento, no âmbito nacional, de novos projetos semelhantes com objetivo de produzir e distribuir informações de uma forma mais ampla, por meio do uso de um número maior de recursos da tecnologia digital, o que é interessante pois, as bibliotecas brasileiras são instituições sociais que podem ajudar na preservação da

\footnotetext{
${ }^{28}$ Prossiga - é um dos projetos de biblioteca virtual mais importantes no Brasil. Foi criado pelo CNPq para facilitar a busca de informações por parte de seus pesquisadores. Ao garantir rapidez de acesso a conteúdos úteis para o desenvolvimento de projetos, a instituição contribui para a redução dos custos dos estudos, além de difundir seus resultados para um maior número de pessoas. Seu site é: www.prossiga.br
} 
herança cultural e na administração de sistemas de informação científicotecnológicos e de negócios do país.

Uma parte da sociedade que poderá beneficiar-se do acervo da Bibvirt, caso os problemas com as licitações dos computadores sejam resolvidos, é a representada pelos estudantes de ensino médio de escolas públicas brasileiras. Segundo o presidente Fernando Henrique Cardoso em notícia apresentada no jornal do MEC Ministério da Educação - de março de 2001, serão investidos até o final de 2002 aproximadamente um bilhão de reais, do Fundo de Universalização dos Serviços de Telecomunicações - FUST, para equipar as 13.227 escolas públicas de ensino médio com computadores e acesso à Internet. São 250.000 computadores que serão utilizados diretamente por sete milhões de estudantes. No entanto, até o término da redação desta dissertação de mestrado, em janeiro de 2002, uma liminar concedida aos deputados Sérgio Miranda ${ }^{29}$ (PCdoB/MG) e Walter Pinheiro (PT/BA) impedia a licitação dos computadores, pois alegaram ser o edital da Anatel irregular.

Caso esta questão seja resolvida e os computadores enviados as escolas, os estudantes terão a oportunidade de aprender a buscar informação, trabalhar sobre ela e divulgar suas idéias, utilizando as informações existentes na Internet, entre elas as existentes nas bibliotecas virtuais, contribuindo para o desenvolvimento intelectual de nosso País.

\footnotetext{
${ }^{29}$ Gabinete do Deputado Sérgio Miranda (PCdoB/MG) - 05/11/2001. Mantida liminar que impede licitação irregular de computadores nas escolas
}

O juiz substituto da $6^{\text {a }}$ Vara Federal de Brasília, Carlos Eduardo Castro Martins, manteve hoje, 05 de novembro, a liminar concedida aos deputados Sérgio Miranda (PCdoB/MG) e Walter Pinheiro (PT/BA) suspendendo o edital irregular da Anatel que pretende comprar 290 mil computadores a escolas de ensino médio e profissionalizante das empresas de telecomunicações com os recursos do Fundo de Universalização dos Serviços de Telecomunicações (Fust).

Quando foi publicado o edital, não havia previsão dessa despesa no Plano Plurianual da União, em desrespeito ao artigo 17 da Lei de Responsabilidade Fiscal. Por essa e outras irregularidades, a Justiça suspendeu o edital. No dia 29 de outubro, foi sancionada a lei que inclui o Programa Telecomunidade no PPA. Já no dia seguinte a Anatel apresentou pedido de reconsideração tentando retomar o processo licitatório. Mas o juiz considerou que a inclusão dessas despesas no PPA não sustam a ilegalidade, pois a verba deve preceder a publicação do edital de licitação.

Vale ressaltar que a lei que alterou o PPA incorporou modificações que obrigam o fornecimento de computadores dotados de dois sistemas operacionais, derrubando o privilégio que o edital conferia à Microsoft. Porém, o edital que a Anatel quer levar adiante não contempla essa exigência legal.

Os setores que hoje acompanham o desfecho dessa história esperam que o Edital seja republicado e as suas ilegalidades corrigidas. A Anatel ao insistir no erro tem atrasado a informatização das escolas. 
Já quase no final desta dissertação de mestrado, em 13 de dezembro de 2001, uma outra notícia foi apresentada pelo Boletim Informativo do Governo Eletrônico ${ }^{30}$ falando que a partir do próximo ano o Governo Federal iniciará o processo de seleção para implementar o programa "Bibliotecas Públicas". O trabalho vai permitir que todas as bibliotecas de instituições públicas ou mesmo acervos de organizações da sociedade civil consideradas de interesse público possam ser incluídos dentro de uma rede virtual, com seu conteúdo oferecido através do acesso on-line via Internet.

Como esse programa também será financiado pelo FUST e implementado pela Agência Nacional de Telecomunicações - Anatel, devemos olhar com certa desconfiança para a efetiva implementação dessa proposta devido aos problemas que estes dois órgãos já estão enfrentando com propostas anteriores.

\subsubsection{Biblioteca Virtual do Estudante Brasileiro}

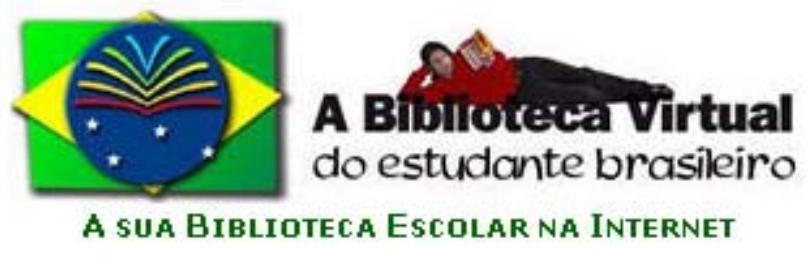

A Biblioteca Virtual do Estudante Brasileiro da Escola do Futuro da Universidade de São Paulo foi criada em setembro de 1997, pela Escola do Futuro da Universidade de São Paulo (ver Anexo 3), tendo como objetivo principal fornecer material de estudo e pesquisa, com qualidade, para alunos de ensino fundamental e médio, de escolas públicas e privadas.

A concepção e autoria da proposta foram do coordenador científico da Escola do Futuro da Universidade de São Paulo, Prof. Dr. Fredric Michael Litto. Desde seu lançamento em setembro de 1997, a Bibvirt já teve como coordenadores de produção: Ana Cândida Becker, Roberto Kirschbaum, Andréa Gonçalves, Silvia Ricardo e Carlos Seabra.

${ }^{30}$ Boletim Informativo do Governo Eletrônico. Programa permitirá acesso ao conteúdo de bibliotecas de todo o País. Brasília, 13 a 20 de dezembro de 2001. Available from Internet <URL: http://www.governoeletronico.gov.br/noticias.cfm?id noticias=511> [16.12.2001] 
O impulso inicial para o desenvolvimento da Biblioteca Virtual do Estudante Brasileiro - Bibvirt, foi dado pela AT\&T Foundation ${ }^{31}$, que financiou US $\$ 100,000.00$, e pela Secretaria de Estado da Cultura de São Paulo ${ }^{32}$, que financiou US $\$ 40,000.00$ Contou também com o apoio do $\mathrm{ICDE}^{33}$ (International Council for Distance Education) que apoiou o processo de seleção e acompanhamento do financiamento da AT\&T Foundation.

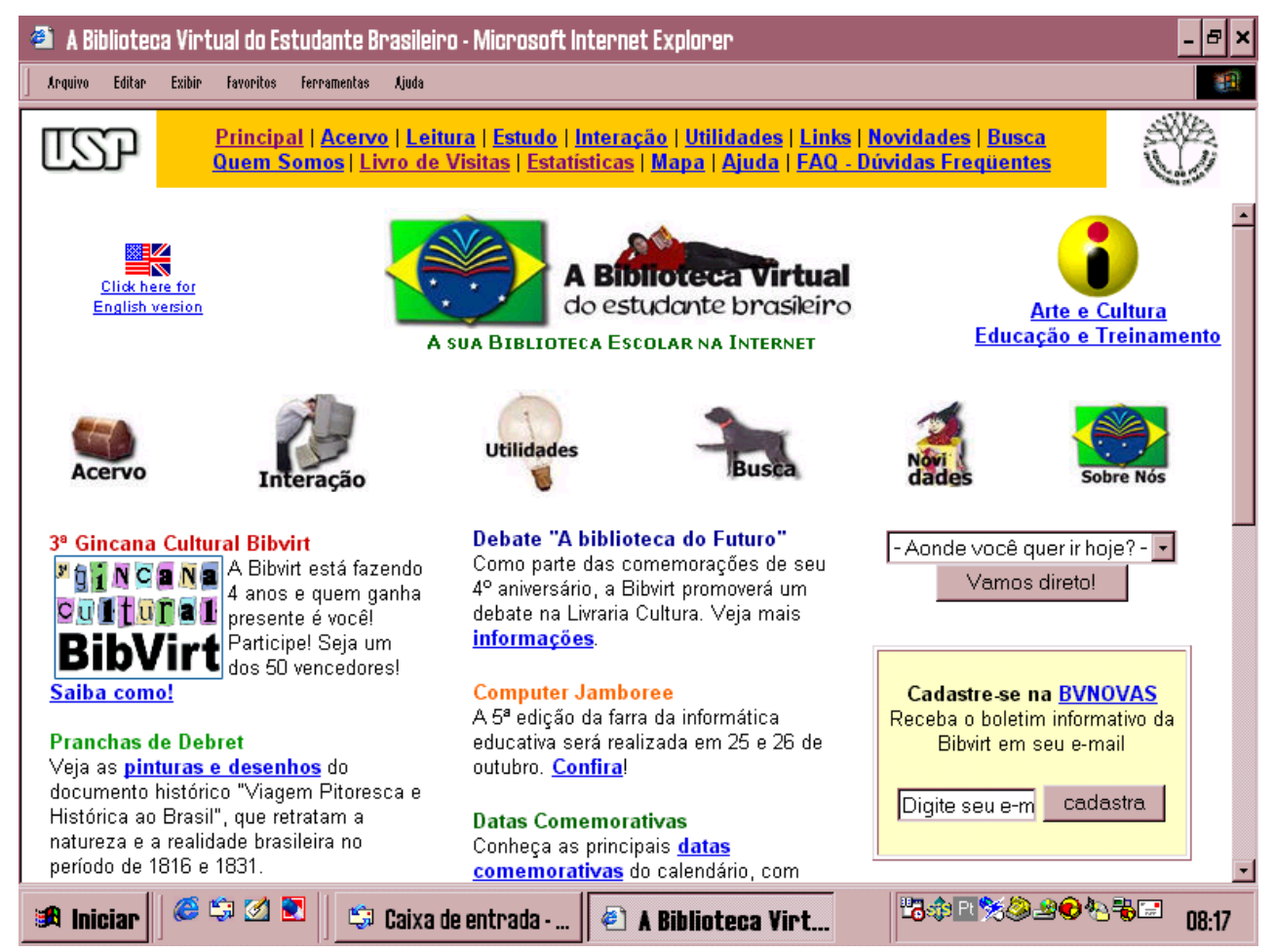

Figura 1 - Tela de abertura do site da Bibvirt

Um ano depois (1998), a Fundação Roberto Marinho ${ }^{34}$ e o Sistema Fiesp ${ }^{35}$ (Federação das Indústrias do Estado de São Paulo) deram uma nova contribuição na área de acervo, autorizando a utilização do material, em forma digital, do Telecurso 2000.

\footnotetext{
Entidades parceiras iniciais do projeto Biblioteca Virtual do Estudante Brasileiro

${ }^{31}$ AT\&T Foudation - <URL:http://www.att.com/foundation/ >[16.12.2001]

${ }^{32}$ Secretaria de Estado da Cultura de São Paulo -

$<$ URL:http://www.saopaulo.sp.gov.br/linha/sec cult.htm> [16.12.2001]

33 ICDE (International Council for Distance Education )- <URL: http://www.icde.org/> [16.12.2001]

${ }^{34}$ Fundação Roberto Marinho - <URL: http://www.frm.org.br/> [16.12.2001]

${ }^{35}$ Fiesp (Federação das Indústrias do Estado de São Paulo) -

<URL:http://www.fiesp.org.br/spex/> [16.12.2001]
} 
O trabalho desenvolvido pela Bibvirt tem sido amplamente reconhecido. Nos três anos consecutivos do concurso "iBest ${ }^{36}$, em diversas categorias, a Bibvirt foi aclamada com 5 troféus:

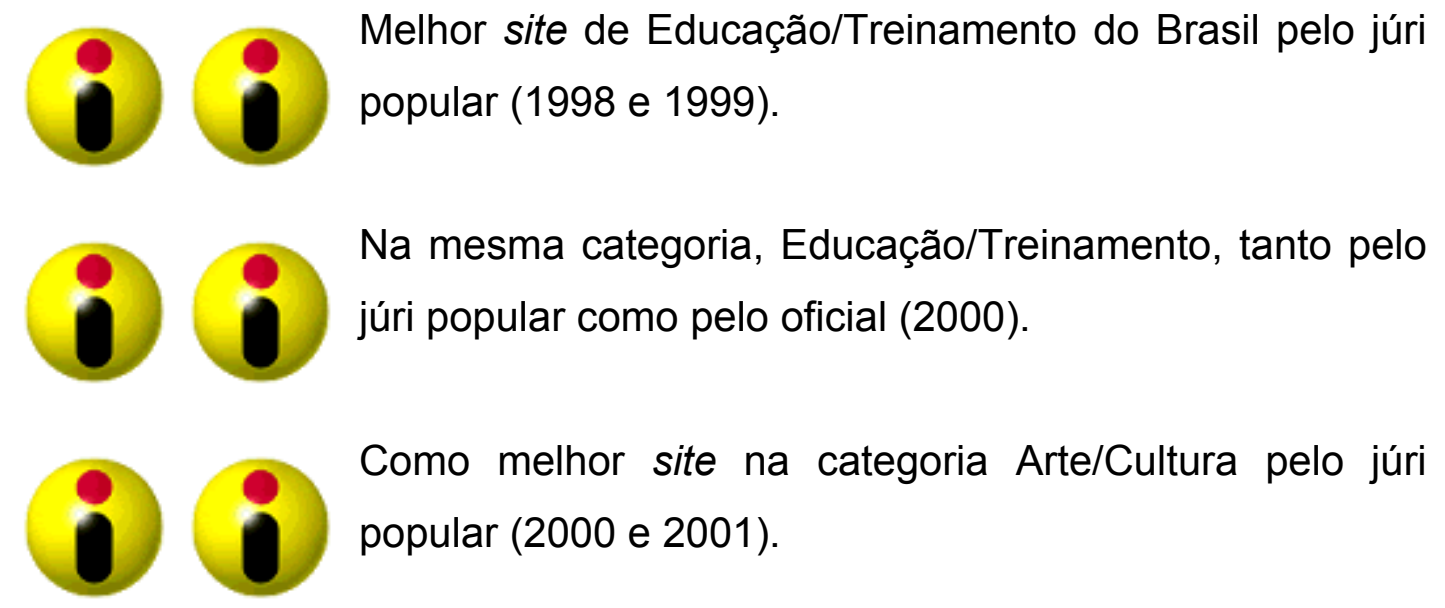

Este sucesso da Bibvirt é repetido diariamente, visto através das estatísticas do uso do site, que diariamente, durante o ano de 2001, teve uma média de mais de 5000 acessos discretos.

A Bibvirt tem como principais objetivos oferecer recursos educacionais úteis para pesquisa a estudantes e professores dos ensinos fundamental e médio e de escolas técnicas, como também ajudar a suprir a carência de bibliotecas escolares no país ${ }^{37}$

\footnotetext{
${ }^{36}$ A idéia do Prêmio iBest, uma iniciativa que tinha como principal objetivo descobrir novos talentos e premiar todo o esforço dos profissionais e dos sites que estavam fazendo a história da Internet no Brasil, surgiu no ano de 1995. "Naquela época", explica Marcos Wettreich, "sabíamos que o desenvolvimento da Internet no país se dava de forma exponencial, porém muito desorganizada, uma das características da World Wide Web. Conversando com alguns profissionais da nossa equipe e com executivos de portais horizontais e sites pioneiros, tivemos a idéia de conceber um prêmio que englobasse toda a comunidade de Internet. A proposta foi rapidamente encampada por internautas de todo o País." Saiba mais em: www.ibest.com.br [04.12.2001]
}

\section{${ }^{37}$ Dados do Censo Escolar 2000 revelam condições de infra-estrutura de estabelecimentos de ensino fundamental e médio}

No ensino médio, $87 \%$ (7.127.865) dos alunos freqüentam escolas que possuem bibliotecas. Esses estabelecimentos correspondem a $82 \%$ do total no País, segundo o Censo Escolar 2000. A maioria das escolas deste nível de ensino, 97\%, está na zona urbana.

No ensino fundamental, dos 35.717 .948 alunos matriculados em todo o País, $58 \%$ (20.862.982) estudam em escolas que possuem bibliotecas. Quando se leva em conta o número de estabelecimentos, $25 \%$, possuem bibliotecas. 
e de materiais de qualidade em Língua Portuguesa na Internet. Outro objetivo é contribuir para a infra-estrutura de ensino a distância mediada por computadores (elearning).

As principais missões assumidas pela Bibvirt são:

- Disponibilizar gratuitamente vasta quantidade de informação textual e audiovisual qualificada, atualizada e facilmente acessível via Internet, proporcionando auxílio às pesquisas escolares, e servindo como subsídio para o desenvolvimento de atividades curriculares e extra-curriculares.

- Oferecer um ambiente dinâmico e interativo, que promova a motivação dos estudantes pela pesquisa e o aperfeiçoamento de suas habilidades de busca de informação, respeitando e estimulando a liberdade de investigação de todos os pontos de vista.

- Acelerar a modernização da Educação Brasileira, e ajudar a reduzir o isolamento das áreas rurais e pequenas comunidades em todo Brasil.

- Facilitar o desenvolvimento de recursos humanos para a Era da Informação, familiarizando-os com o uso das novas tecnologias de comunicação em aplicações educacionais.

A Bibvirt está disponível gratuitamente, 24 horas por dia, sete dias por semana, através da Internet no site http://www.bibvirt.futuro.usp.br. Seu conteúdo compõe-se basicamente de três partes: um acervo, uma área de atividades interativas e uma seção de links.

O número de alunos atendidos é proporcionalmente maior que a quantidade de estabelecimentos no ensino fundamental devido à grande quantidade de escolas rurais. Em 2000 , dos 181,5 mil estabelecimentos que ofereciam ensino fundamental, 62\% (112 mil) são rurais, mas detêm apenas $18 \%$ da matrícula.

Available from Internet <URL:http://www.inep.gov.br/imprensa/noticias/censo/escolar/news01 3.htm> [15.12.2001] 
- O acervo compreende textos integrais de obras literárias, livros didáticos e paradidáticos, imagens, sons, artigos e documentos. Ali encontram-se, entre outros materiais, dezenas de

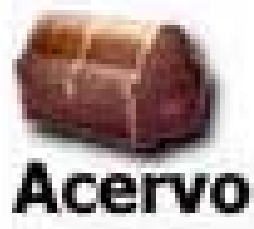
obras de Literatura Brasileira e Portuguesa, e em breve de Literatura Estrangeira (Projeto Gutenberg) $)^{38}$, a coleção de livros do Telecurso 2000, sons de aves e instrumentos musicais brasileiros, vozes de diversas personalidades em discursos históricos, artigos sobre Educação e parte do acervo permanente do Museu de Arqueologia e Etnologia da Universidade de São Paulo.

- A área de atividades interativas privilegia a interação dos usuários com o site e dos usuários entre si. Conta com um livro de relatos, destinado a receber descrições de experiências dos usuários na utilização da Bibvirt para o processo de ensino/aprendizagem, um mural de

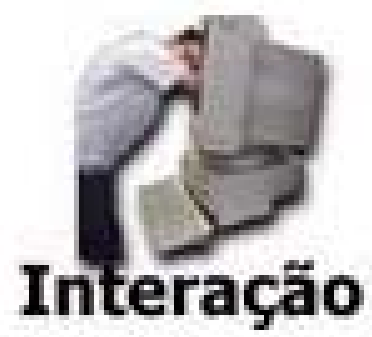
recados onde os usuários podem compartilhar dicas, notícias e eventos, e uma pesquisa cujos resultados levam a conhecer melhor o perfil dos visitantes da Bibvirt.

- A seção de Links, organizada por assuntos, destaca outras fontes de pesquisa na rede, servindo como complemento aos recursos oferecidos pela Bibvirt, sendo constantemente

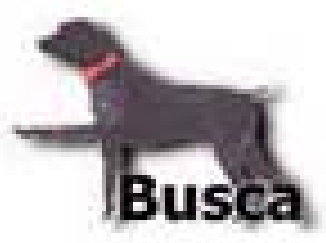
atualizada e ampliada.

\footnotetext{
${ }^{38}$ O Projeto Gutenberg talvez seja a mais conhecida das diversas iniciativas de disponibilizar na Internet (através de trabalho voluntário e de doações) os textos completos de livros cujos direitos autorais encontram-se vencidos. Tal projeto pretende, até 31 de dezembro de 2001, colocar gratuitamente à disposição dos usuários da rede milhares de textos eletrônicos. Estes documentos são disponibilizados em ASCII, uma vez que, conforme observa Michael Hart, o organizador do projeto, sistemas operacionais e programas se obsoletizam, mas plain vanilla text não. http://www.promo.net/pg/
} 
A Biblioteca Virtual do Estudante Brasileiro não tem como proposta substituir a biblioteca não virtual. Nada substitui o prazer sentido quando visitamos uma biblioteca e manuseamos livros impressos. "A Bibvirt é o 'amendoim' antes do 'banquete' que é a leitura de um livro segurado na mão", diz o criador da Bibvirt.

Litto $^{39}$ (1999) comenta em seu trabalho que o livro continua sendo importante para todos que lidam com Educação; mas não podemos negar a importância da direta relação entre as novas formas de pensar e de atuar que as novas tecnologias de informação estão propiciando e a criação de ambientes de trabalho e aprendizagem continuada, caracterizada não pela solidão e isolamento, mas pela socialização constante e intensa.

Sendo assim, a Bibvirt pode ser uma importante alternativa para pesquisas escolares e atividades

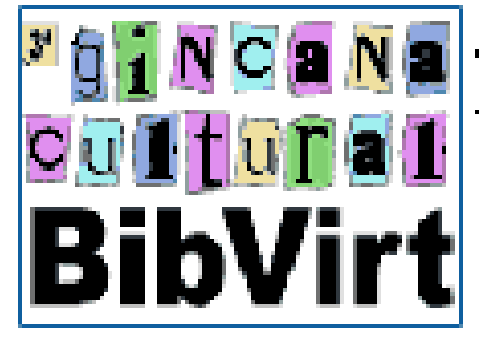
interativas, para alunos e professores, em qualquer lugar, potencializando as atividades pedagógicas e as trocas de experiência entre seus pares.

A Biblioteca Virtual do Estudante Brasileiro - Bibvirt - permite que o usuário veja uma estante de livros que contém um sub-conjunto de livros de toda a biblioteca que mais se aproxima do seu perfil, ou uma necessidade particular de informação expressa anteriormente. O usuário pode olhar os títulos dos livros, fazer download ou ler na tela, ou seja, tocar virtualmente qualquer livro de seu interesse.

Diante da mudança de paradigma e a relevância do papel das bibliotecas, no cenário nacional e internacional, um estudo da Bibvirt é importante e necessário, pois permitirá melhorar a qualidade de acesso e recuperação de suas informações, contribuindo também para a formulação de políticas que visem à cooperação para tornar o acesso cada mais aberto e levado aos locais mais longínquos, tendo como base o uso de novas tecnologias sob comando de componentes humanos.

\footnotetext{
${ }^{39}$ LITTO, F. Anais do Fórum Mineiro de Educação. Uberlândia. MG. 1999
} 


\subsection{Objetivo da Pesquisa}

Dois foram os fatores determinantes para o desenvolvimento desta pesquisa:

- A importância da Bibvirt para o cenário nacional, pois são poucos os sites na Internet que oferecem material confiável e de qualidade em Língua Portuguesa para alunos de ensino fundamental e médio, de escolas públicas ou privadas e residentes em qualquer lugar do Brasil ou do mundo.

- A necessidade de se avaliar o processo de busca e recuperação de informações no site, pois se um dos principais objetivos da Bibvirt é fornecer material de qualidade de fácil acesso e recuperação, é necessário uma análise de como os usuários buscam informação e como o sistema pode melhor ser projetado para atender suas necessidades.

Os objetivos da pesquisa residem na investigação do perfil dos usuários da Biblioteca Virtual do Estudante Brasileiro, com maior ênfase nas possibilidades e limites em processos de busca e recuperação de informações no seu acervo.

Questões centrais serão abordadas a fim de se atingir os objetivos propostos e, ao final desta análise, elaborar-se-á uma proposta para melhorar a busca e a recuperação das informações na Bibvirt. 


\section{CAPÍTULO 2}

\section{Metodologia da Pesquisa}

"Há momentos, em um trabalho científico, que temos que saber andar por entre as árvores de uma floresta.

Mas também, há outros momentos que devemos saber observá-las de cima e entendê-las como um todo." Fredric Litto 


\section{Metodologia da Pesquisa}

\subsection{Justificativa}

Este trabalho se pautou em uma revisão bibliográfica para a contextualização dos tópicos relacionados a Bibvirt: Internet, informação, bibliotecas virtuais e nomenclatura. Em paralelo, a necessidade de definição dos parâmetros para seu estudo, remeteu a uma bibliografia sobre análises de processos de busca e recuperação de informações e metodologias para avaliação de ensino a distância.

A primeira fonte bibliográfica levada em consideração para análise, por estar presente no sumário executivo original da Bibvirt (ver Anexo 1), foi a metodologia desenvolvida por Bates ${ }^{40}$ (1995), voltada à avaliação de tecnologias para educação a distância.

Como esta foi elaborada para avaliação de tecnologias em educação a distância e não necessariamente destinada a avaliação de bibliotecas virtuais, ela não aprofunda na investigação de processos de busca e recuperação de informações que são pontos fundamentais para o sucesso da Bibvirt. Com isso, foi necessário recorrer a outras fontes que contribuíssem para uma análise mais completa desses aspectos.

Nesse processo, muitos textos foram analisados e diversas informações relevantes foram encontradas apontando, dentre diversos aspectos comportamentais, o que faz um usuário buscar uma informação. Ou seja, o que leva o usuário a visitar uma biblioteca presencial ou navegar na Internet a procura de informações.

Em uma das fontes analisadas, Gianesi e Correa ${ }^{41}(1984)$ apresentam a idéia de que o indivíduo identifica uma necessidade de informação quando sente uma discrepância (lacuna) entre seu estado atual e o estado desejado. Isto significa que

\footnotetext{
${ }^{40}$ BATES, T. Technology, Open Learning and Distance Education. New York: Routledge Studies in Distance Education, 1995. 266 p.

${ }^{41}$ CORREA, H. L.; GIANESI, I. G.N. Administração estratégica em serviços. São Paulo: Atlas, 1994. $233 \mathrm{p}$.
} 
ele procurará suprir essa necessidade buscando informações a partir de, basicamente, quatro fontes: pessoais, comerciais, públicas ou experimentais.

Freire $^{42}$ (1986) também diz que no dia-a-dia os indivíduos se deparam com tarefas que deflagram a dúvida, o mal-estar e também o prazer, surgindo a necessidade de se buscar informações. O mal-estar pode aparecer porque muitas vezes nessas tarefas aparecem as diferenças, os conflitos, o desconhecido. Também pode surgir o prazer, por essa sensação possibilitar a apropriação do que antes era desconhecido, um saber construído.

Em outras palavras, toda tarefa parte do que o indivíduo sabe para se deparar com o que ainda não conhece. Portanto, toda tarefa é constituída por uma área de saber conhecido e outra ainda ignorante que só será reconhecida depois que novas informações forem incorporadas.

Segundo Freire (1986), referenciando as idéias de Vygotsky, toda tarefa se constitui, assim, de questões que um indivíduo consegue elaborar, circunstância chamada de "zona real", e de outras que ainda não consegue resolver, chamada de "zona proximal”.

Levando em consideração a constatação feita por Gianesi e Correa (1994) e também a apresentada por Freire (1986), é possível concluir que é na interação com o outro, com fontes de informação diversificadas, que o indivíduo consegue elaborar suas idéias, transformando sua "zona proximal" em "zona real", ou seja, suprindo a lacuna inicial por ele encontrada.

$\mathrm{Na}$ tentativa de preencher a lacuna, o indivíduo vive um processo que foi objeto de estudo de um trabalho desenvolvido por Kuhlthau $(1983)^{43}$, no qual ela discute a procura de informação na perspectiva do usuário e apresenta um modelo para análise de processos de busca de informação oriundo de uma série de cinco

\footnotetext{
${ }^{42}$ FREIRE, M. Sobre tarefa e construção do conhecimento. Série cadernos de reflexão. São Paulo: Espaço pedagógico, 1986.
}

${ }^{43}$ KUHLTHAU, C. C. Seeking Meaning: a process approach to library and information services. Norwood, NJ: Ablex, 1983. 
estudos que investigaram experiências habituais de usuários na procura de informações em bibliotecas presenciais. Kuhlthau (1983) identificou seis estágios vivenciados por um indivíduo em um processo de busca de informação:

- Iniciação - identificação da necessidade de informação (lacuna).

- Seleção - identificação e seleção de um tópico geral a ser investigado.

- Exploração - investigação de informações de um tópico geral para expandir um entendimento pessoal.

- Formulação - concentração focada em um tópico de uma informação encontrada.

- Coleção - reunião de informações coletadas para um tópico focado.

- Apresentação - finalização da pesquisa e preparo da apresentação com suas descobertas.

Observando o fluxo de informações com as quais convivemos no nosso dia-a-dia podemos dizer que cada vez mais os indivíduos se defrontam com uma série de lacunas e que no processo de busca e recuperação de informações, passam pelos seis estágios definidos por Kuhlthau (1983). Com isso, a agilidade para suprir uma lacuna, por muitas vezes pode ser fator determinante.

Diante dos fatos apresentados, existe uma necessidade real de encontrarmos cada vez mais fontes confiáveis de informação que desencadeiem em processos de busca e recuperação de informações eficientes, evitando que a transição da "zona proximal" para a "zona real" seja uma angústia ou um mal-estar, e sim que seja um prazer.

E é pensando em processos de busca de informação eficientes que encontramos o trabalho de Dervin $(1983)^{44}$ e uma das principais fontes metodológicas para esta pesquisa. Em seu trabalho, Dervin desenvolve uma abordagem, chamada "Sense Making", que faz um estudo da necessidade de informação sob a ótica do usuário,

\footnotetext{
44 DERVIN, B. An overview of Sense-Making research: concepts, methods and resultes to date. (on line) In: International Communications Associations Annual Meeting. Dallas, May, 1983. Available from Internet: <URL: http:// www.eca.usp.br/prof/sueli/sm1983 4.html> [01.12.2001]
} 
demonstrando a necessidade de deslocarmos a ênfase de análise no sistema para a necessidade de concentrarmos o estudo no usuário.

Como apresentado por ela, o enfoque deve centrar-se nos problemas do usuário e na atribuição de sentido que ele faz, salientando que a eficiência da recuperação da informação deve levar em conta a integração dos resultados na vida do usuário e na avaliação que ele faz da utilidade da informação para a solução de seus problemas.

Sendo a abordagem Sense-Making um dos principais métodos usados nesta pesquisa, para melhor entendimento da metodologia utilizada no estudo da Bibvirt, será feita sua apresentação em mais detalhes, assim como a apresentação do modelo Actions desenvolvido por Bates.

\subsection{Metodologias Relacionadas}

\subsubsection{O Modelo Actions}

Este conceito foi desenvolvido em 1995 por Bates ${ }^{45}$, então Diretor Executivo para Pesquisa, Planejamento Estratégico e Tecnologias da Informação na Open Learning Agency, em British Columbia. Antes disso, Bates foi professor da disciplina "Pesquisa de Mídias na Educação", na Open University, no Reino Unido.

Em 1996, Bates - a convite da Escola do Futuro da USP - esteve no Brasil, deu conferências e orientou a pessoa responsável pela avaliação da Bibvirt na época, Ana Luiza Mattos da Faculdade de Educação da Universidade de São Paulo, para fazer a avaliação utilizando seu modelo. Infelizmente, essa pessoa não concluiu a pesquisa e não foi possível ter acesso à orientação feita por Bates.

O estudo de Bates se dirige às instituições educacionais, departamentos de governo, treinamentos organizacionais e negócios que procuram inovações e um custo efetivo para prover qualidade educacional e treinamento para seus estudantes ou clientes, e quem mais estiver usando educação a distância.

\footnotetext{
${ }^{45}$ BATES, T. Technology, Open Learning and Distance Education. New York: Routledge Studies in Distance Education. p. 33-87, 1995.
} 
O estudo oferece um modelo para ajudar na tomada de decisão sobre qual tecnologia utilizar para educação a distância. Também recomenda que alguns cuidados sejam tomados na escolha da tecnologia a ser usada nessa modalidade, pois a escolha apropriada de uma tecnologia, bem como seu uso, dependem do contexto particular em que serão trabalhadas.

Bates argumenta que nenhuma tecnologia, a princípio, é boa ou má para a aprendizagem - ela é somente um caminho para ajudar professores ou administradores a resolverem seus problemas.

Ele nos leva a perceber que a escolha da tecnologia a ser usada para aprendizagem não é somente um assunto técnico e que para isso, vários fatores devem ser considerados, como descrito no modelo Actions que ajuda no processo de tomada de decisão de qual tecnologia usar para a função de aprendizagem que se deseja oferecer.

O modelo é formado por um conjunto de vários tópicos, representado pela sigla ACTIONS como apresentado abaixo:

Access (Acesso): a tecnologia é acessível a qualquer estudante que queremos atender?

Costs (Custos): qual é o custo para elaboração e manutenção da tecnologia em todo o processo?

Teaching functions (Funções de Aprendizagem): o que o estudante pode realmente aprender por meio desta tecnologia?

Interactivity and user-friendliness (Interatividade e Uso Amigável): os usuários têm facilidade para interagir com a tecnologia?

Organizational issues (Assuntos Organizacionais): que mudanças são necessárias e devem ser feitas para melhor atender ao usuário?

Novelty (Originalidade): quão inovadora é essa tecnologia?

Speed (Velocidade): com que rapidez o conteúdo pode ser atualizado e como é a velocidade de acesso para o usuário? 
Bates aponta que esse modelo pode ser aplicado para análise de tecnologias, tais como: material impresso, rádio, TV, aprendizagem através do computador e multimídia.

Usando esse esquema, Bates analisa as resistências que podem ser apresentadas por futuros usuários e os pontos fracos de cada tecnologia, oferecendo uma compreensão do uso da tecnologia em processos educacionais, custos comparativos e análise da cada uma delas. Finalmente ele provê uma visão da tecnologia baseada na aprendizagem aberta no século XXI.

No caso da Bibvirt, uma análise utilizando como referência esse modelo, permite delinear sua abrangência, apontando quem são seus usuários, a possibilidade de acesso oferecida a eles e o quão importante ela é no processo de busca e recuperação de informações para usuários no ambiente virtual.

\subsubsection{A Abordagem Sense-Making}

Como apresentado por Ferreira $(1998)^{46}$ e transcrito aqui, a abordagem SenseMaking começou a ser desenvolvida em 1972 pela Professora Dra. Brenda Dervin, Ph.D. em Ciências da Comunicação, docente do Departamento de Comunicações da Ohio State University, na cidade de Columbus, Ohio, Estados Unidos.

Mas, somente em maio de 1983, na "International Communications Association Annual Meeting" - encontro anual da Associação de Comunicação Internacional em Dallas - Texas - Estados Unidos, é publicado o documento contendo a base filosófica, conceitual, teórica e metodológica de Dervin $(1983)^{47}$.

Esta abordagem mapeia as necessidades de informação sob a ótica do usuário. É um método para estudar como as pessoas (individual ou coletivamente) numa situação (tempo/espaço) de pacientes, ouvintes, usuários, clientes, cidadãos,

\footnotetext{
${ }^{46}$ FERREIRA, S. M. S P. A abordagem Sense-Making.1998. Available from Internet: <URL: http://www.eca.usp.br/nucleos/sense/oque.htm>. [01.12.2001]

47 DERVIN, B. An overview of Sense-Making research: concepts, methods and results to date. (on line) In: International Communications Associations Annual Meeting. Dallas, May, 1983. Available from Internet: <URL: http:// www.eca.usp.br/prof/sueli/sm1983 4.html> . [01.12.2001]
} 
percebem, compreendem, sentem e constroem o seu mundo, através da observação, interpretação e compreensão do mundo exterior; como constroem a sua realidade que não é completa, nem constante, mas cheia de lacunas e de descontinuidades (questionamentos, barreiras, confusões e dilemas) e como identificam a necessidade e usam a informação no processo de fazer sentido e preencher suas lacunas.

A partir desta nova abordagem, os estudos de comportamento e uso da informação têm divergido em duas direções apresentadas por Dervin e Nilan $(1986)^{48}$ : abordagem tradicional e abordagem alternativa.

\section{Abordagem Tradicional}

São estudos direcionados sob a ótica do sistema de informação ou biblioteca, voltados para o "conteúdo" ou para a "tecnologia". A ênfase da abordagem está na maneira com que o sistema afeta o armazenamento, acessibilidade e a disseminação da informação ou do conhecimento.

Baseado em seus resultados, esses estudos têm prescrito tamanhos, formatos, dinâmicas e mesmo os tipos de materiais a serem incorporados aos sistemas de informação, pois considera que a informação é algo objetivo, existente fora das pessoas e passível de ser transferida de uma para outra.

Portanto, parece ser possível que a eficiência e o sucesso das operações de um sistema possam ser medidos em função do número de fontes de informações recuperadas pelo sistema versus o que realmente for de interesse do usuário. Isso coloca o usuário como um processador imperfeito de informações, pois sabemos que nem todas as pessoas se interessam pelas mesmas fontes indicadas.

Conforme observado por Rhode $(1986)^{49}$, costuma-se ignorar o fato de que o ser humano cria sua própria realidade e tem seus próprios estoques internos de

\footnotetext{
48 DERVIN, B.; NILAN, M. Information needs and uses. In: M. Williams, ed. Annual Review of Information Science and Technology, v.21, p. 3-33, 1986.

${ }^{49}$ RHODE, N. F. Information needs. In: W. Simonton, ed. Advances in Librarianship, v.14 , p. 49-73, 1986. New York: Academic Press.
} 
informação, os quais serão usados para compreender as informações externas e as diferentes situações em que os indivíduos se encontram em determinado momento.

Nos estudos tradicionais os sistemas são examinados somente através das características grupais e demográficas de seus usuários. Os atributos demográficos (sexo, idade, raça, religião e renda familiar) não são indicadores potenciais do comportamento de busca e uso da informação.

A abordagem tradicional não tem examinado os fatores que geram o encontro do usuário com os sistemas de informação ou as conseqüências de tal confronto, limitando-se à tarefa de localizar fontes e informação, desconsiderando as etapas de interpretação, formulação e aprendizagem envolvidas no processo de busca de informação, sendo que com o aumento de acesso a informações há a necessidade de serviços centrados no significado da busca mais do que meramente na localização da fonte.

\section{Abordagem Alternativa}

Conhecida, também, como "abordagem centrada no usuário" ou ainda "abordagem da percepção do usuário", estes estudos de comportamento de usuários se caracterizam por:

- Observar o ser humano como sendo construtivo e ativo.

- Considerar o indivíduo como sendo orientado simultaneamente.

- Visualizar holisticamente as experiências do indivíduo.

- Focalizar os aspectos cognitivos envolvidos.

- Analisar sistematicamente a individualidade das pessoas.

- Empregar maior orientação qualitativa.

Neste sentido, Taylor $(1984)^{50}$ defende a idéia de que devemos enfocar, prioritariamente, nos estudos alternativos, o problema individual dos usuários. Que informação um indivíduo quer encontrar no sistema de informação, que uso fará dela, e como o sistema pode melhor ser projetado para preencher essas

\footnotetext{
${ }^{50}$ TAYLOR, R. The Value-added Processes in Document-Based Systems: Abstracting and Indexing Services. In: Information Services and Use. V.4. № 3. Pg. 127-46. 1984 June.
} 
necessidades de informação, dependerão exclusivamente dele próprio, de seu propósito na busca de informação e do uso da mesma na transposição das lacunas.

Portanto, qualquer tentativa de descrever padrões de busca de informação deve admitir o indivíduo como o centro do fenômeno e considerar a visão, necessidades, opiniões e dificuldades desse indivíduo como elementos significantes e influentes que merecem investigação.

Necessidades de informação, ainda, devem ser definidas em plano individual, destacando-se atenção para o tempo e espaço específicos experimentados por cada um desses elementos em particular.

A abordagem alternativa ao posicionar informação como algo construído pelo ser humano está visualizando o indivíduo em constante processo de evolução, livre para criar o que quiser junto aos sistemas ou às situações.

Essa abordagem se preocupa em entender como as pessoas chegam à compreensão das coisas, pesquisando por dimensões passíveis de generalizações dessa tomada de consciência (ou de compreensão), identificando o processo de uso da informação em situações particulares.

A base conceitual do Sense-Making foi desenvolvida com suporte nas teorias de vários estudiosos, como BRUNER \& PIAGET (cognição); ASCROFT, BELTRAN \& ROLING (teoria crítica); JACKINS \& ROGER (terapia psicológica) e principalmente em CARTER (teórico da comunicação), que afirma que o homem cria idéias para transpor os "vazios" (lacunas) que aparecem em decorrência da descontinuidade sempre presente na realidade. 
Os enunciados básicos da abordagem Sense-Making, segundo Dervin (1983), podem ser sinteticamente apresentados:

- A realidade não é completa nem constante; ao contrário, é permeada de descontinuidades fundamentais e difusas "vazios" (lacunas).

- A informação não é algo que exista independente e externamente ao ser humano, ao contrário, é um produto da observação humana sobre si próprio e sobre os outros.

- O Sense-Making assume que toda "informação é subjetiva", desde que se considere a produção de informação como sendo guiada internamente.

- Busca e uso da informação são vistas como atividades construtivistas, como criação pessoal do sentido individual do ser humano.

- Foco deve estar no modo como os indivíduos usam as informações tanto de outras pessoas, como as suas próprias, para construir sua realidade e direcionar seu comportamento.

- O comportamento dos indivíduos pode ser melhor prognosticado a partir da estruturação de um modelo que focalize mais suas "situações de mudança" do que atributos denominados "características de personalidade" ou "demográfica".

- As pesquisas devem ser por padrões, observando mais do que assumindo conexões entre situações e necessidades de informação, entre informação e uso.

- Considera-se a existência de "compreensões universais da realidade" que permitem prognósticos e explicações melhores do que seria possível obter nas abordagens positivistas tradicionais. 
Para o desenvolvimento dos itens propostos nos enunciados, será apresentada uma metáfora operacional que advém diretamente da idéia de descontinuidade. Cada momento é considerado novo, mesmo que seja repetição de comportamentos passados. Para isso basearemo-nos nas questões a seguir:

- Como o indivíduo interpreta e transpõe este momento?

- Qual estratégia usa para solucionar a situação que gerou a lacuna?

- Como interpreta esse problema e as possibilidades de resolvê-lo?

- Como se move taticamente para isso?

- Como reinicia sua jornada de pesquisa?

A metáfora que gerou o modelo de Dervin, conhecido como modelo de três pontas, construído sobre o trinômio, situação-lacuna-uso, é demonstrada na figura abaixo:

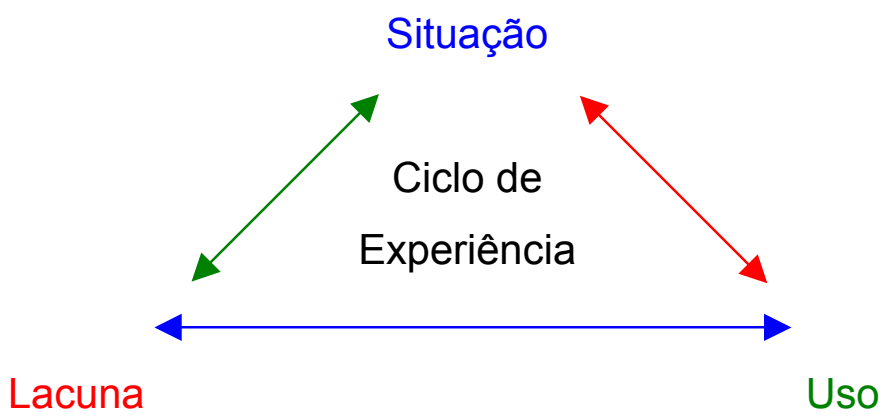

Figura 2 - O Fenômeno do "Sense-Making"

(Dervin ${ }^{51}$, 1999, p.69)

Percebe-se, por esta figura, que conforme o indivíduo se move na vida, passa por várias etapas, onde cada uma em particular pode apresentar novos vazios, novas buscas e novos usos.

A Situação é o espaço mais abrangente deste modelo. É o contexto no qual surge a necessidade de informação, estabelece-se o período em que a busca e o uso da informação vai ocorrer, e chega-se (ou não) à compreensão do problema.

${ }^{51}$ DERVIN, B. Chaos, Order and Sense-Making: A proposed theory for information design. In: JACOBSON, R. ed. Information Design. Cambridge, MA: MIT Press, 1999. 
Dervin (1986) coloca uma situação de necessidade de informação como aquela em que o senso interno individual tende a se esgotar, e a pessoa deve criar novo senso. "Situação é algo que está sempre mudando com o tempo" (Dervin e Nilan $\left.{ }^{52}, 1986\right)$.

No contexto de alguma situação de conflito, o indivíduo encontra uma série de Lacunas, i.e, pontos que não compreende apenas em parte e que o levam a interromper seu caminho. Pode ser definida como a "situação problemática", um estado anômalo de conhecimento (Belkin, Oddy e Brooks, 1982), um estado de incerteza (Krikelas, 1983), uma situação na qual um indivíduo está tentando chegar à compreensão de alguma coisa (Dervin, 1983).

É conseqüência direta da perspectiva defendida por Dervin (1983) sobre a visão humana da realidade, a qual interpreta como sendo algo intersubjetivo e constantemente em mudança. Conceitualmente, a lacuna representa uma oportunidade de informação que auxilia o indivíduo a continuar seu caminho.

Esse mesmo indivíduo é, então, levado a fazer algum tipo de Uso de qualquer ponte que seja construída para transpor o vazio defrontado por ele. Uso, portanto, é o emprego dado ao conhecimento recém adquirido, traduzido na maioria dos estudos de usuários como a informação útil.

Desta forma, ao se tentar estudar e compreender como determinada pessoa percebe sua condição, esta abordagem assume ser imprescindível avaliar esses três pontos básicos - situação-lacuna-uso -, como uma base mínima para autoorientação. "Somente assim se estará respeitando o fato que pessoas percebem o mundo diferentemente" (Dervin,1983).

${ }^{2}$ DERVIN, B.; NILAN, M. Information needs and uses. In: M. Williams, ed. Annual Review of Information Science and Technology, v.21, p. 21, 1986. 
O emprego desta abordagem em estudos de comportamento de busca e uso de informação pressupõe, também, a aceitação dos seguintes atributos:

\section{Individualidade}

Usuários devem ser tratados como indivíduos e não como conjunto de atributos demográficos.

\section{Situacionalidade}

Cada usuário se movimenta através de uma única realidade de tempo e espaço.

\section{Utilidade da informação}

Diferentes indivíduos utilizam a informação de maneira própria e informação é o que auxilia a pessoa a compreender sua situação.

\section{Padrões}

Analisando as características individuais de cada usuário, intento chegar aos processos cognitivos comuns à maioria.

O modelo de Dervin (1986) permite a cada pessoa representar sua própria realidade. $\mathrm{Na}$ verdade, a abordagem "Sense-Making" é um processo humano criativo de compreensão do mundo em um ponto particular no tempo e espaço, limitado pela capacidade psicológica e, ainda, dos acontecimentos ocorridos no presente, passado e futuro de cada indivíduo. Focaliza um ponto no tempo em que a informação é necessária.

\subsection{Conteúdo e Forma do Projeto}

Feito o levantamento bibliográfico e definidas as metodologias que serviriam de apoio para elaboração do questionário, iniciou-se sua estruturação com o apoio da equipe da Bibvirt (ver anexo 5), que sempre colaborou no que foi preciso para viabilizar a pesquisa.

Definiu-se que o modelo Actions seria o fio condutor, por abordar questões centrais que permitem traçar a identidade do usuário da Bibvirt e a abordagem SenseMaking seria utilizada para definir questões mais específicas relacionadas aos itens 
interatividade/uso amigável e aspectos organizacionais, que permitem aprofundar a análise no processo de busca e recuperação de informações.

Nesse processo, o entrelaçamento do modelo desenvolvido por Bates (1995) com a abordagem desenvolvida por Dervin (1986) fez surgir um novo instrumento que pode servir para a avaliação de outras bibliotecas virtuais.

\subsection{Estrutura do Questionário}

O questionário foi elaborado com o objetivo de responder às questões relacionadas aos sete tópicos definidos por Bates (1995):

Access - Acesso

Costs - Custos

Teaching functions - Funções de Aprendizagem

Interactivity and user-friendliness- Interatividade/Uso Amigável

Organizational issues - Assuntos Organizacionais

Novelty - Originalidade

Speed - Velocidade

A apresentação das questões, aos usuários, foi feita de forma única, pois não interessava a eles a forma como seriam analisadas. No entanto, nesta dissertação, para melhor entendimento da metodologia empregada, as questões relacionadas serão apresentadas de forma correlata a cada um dos tópicos.

O questionário no formato original, colocado no site da Bibvirt, pode ser visto no Anexo 4 deste documento. Segue, abaixo, a estrutura desenvolvida para a análise:

2.4.1 Access (Acesso): Quem é o usuário da Bibvirt? De onde ele faz o acesso ao acervo?

Além da necessidade de analisar o fluxo de informações no site da Bibvirt para que ele possa ser melhor projetado e atender as necessidades dos usuários, também é necessário conhecer qual é o público que acessa o site para analisar se o acervo 
atende as suas necessidades. As possibilidades para essas perguntas são diversas, por isso delimitamos as respostas dentro de alguns parâmetros:

Idade

$\square$ abaixo de 9 anos $\square$ de 26 a 29 anos

$\square$ de 10 a 13 anos $\square$ de 30 a 39 anos

$\square$ de 14 a 17 anos $\square$ de 40 a 55 anos

$\square$ de 18 a 21 anos $\square$ mais de 55 anos

$\square$ de 22 a 25 anos

Sexo

$\square$ Masculino $\square$ Feminino

Em que cidade e estado você mora?

Cidade:

Estado:

Qual é a sua principal ocupação?

$\square$ Bibliotecário

$\square$ Estudante de Ensino Fundamental

$\square$ Estudante de Ensino Médio

$\square$ Estudante Universitário

$\square$ Pedagogo $\square$ Professor Ensino Fundamental

$\square$ Professor Ensino Médio

$\square$ Professor Universitário

$\square$ Webmaster

$\square$ Outros:

Qual é a sua renda mensal familiar (em $R \$)$ ?

$\square$ até 300

$\square$ de 301 a 600

$\square$ de 601 a 1200

$\square$ de 1201 a 3000 $\square$ de 3001 a 6000

$\square$ de 6001 a 10.000

$\square$ de 10.001 a 20.000

mais de 20.001

Se você é estudante ou professor, sua escola é: (se você não é estudante ou professor, não responda).

$\square$ Pública

$\square$ Particular 
De onde você mais acessa a Internet?

$\square$ em casa

$\square$ na casa de amigos/parentes

$\square$ na escola/universidade

$\square$ no trabalho

$\square$ na biblioteca

$\square$ outros

2.4.2 Costs (Custos): Qual é o custo para acesso ao acervo da Bibvirt?

Como estamos analisando sob a ótica do usuário, não serão abordados os custos relacionados ao desenvolvimento e manutenção da Bibvirt e sim, somente os custos para acesso ao acervo.

Qual navegador você utiliza com mais freqüência?

$\square$ Explorer até 3.x

$\square$ Explorer até 4.x

$\square$ Explorer até $5 . x$

$\square$ Netscape até 3.x

$\square$ Netscape até $4 . x$

$\square$ Outro

2.4.3 Teaching Functions (Funções de Aprendizagem): Que informação o usuário está procurando na Bibvirt? Que uso fará dela? Ela é adequada às suas necessidades? Ele conta com alguma orientação? Que estratégias de aprendizagem são necessárias para que ele seja capaz de fazer o melhor uso da informação?

Esse tópico foi desenvolvido a partir das idéias apresentadas por Taylor $(1984)^{53}$ segundo os quais ele defende que devemos enfocar, prioritariamente, nos estudos alternativos, o problema individual dos usuários. Devemos analisar que informação um indivíduo quer encontrar no sistema de informação, que uso fará dela, e como o sistema pode melhor ser projetado para preencher a necessidade de informação,

${ }^{53}$ TAYLOR, R. The Value-added Processes in Document-Based Systems: Abstracting and Indexing Services. In: Information Services and Use. V.4. № 3. Pg. 127-46. 1984 June. 
para que dependam exclusivamente dele próprio, de seu propósito na busca de informação e do uso da mesma na transposição das lacunas.

Levando em consideração esses pontos e devido ao grande número de informações a serem analisadas, esse tópico foi dividido em duas partes: a primeira que analisa a necessidade de informação apresentada pelo usuário e a segunda, que relata a forma como o usuário recebe orientação em um processo de busca de informação.

Parte A: questões relativas às necessidades de informação do usuário.

Qual é a sua área de interesse?

$\square$ Material didático para o Ensino Fundamental I

$\square$ Material didático para o Ensino Fundamental II

$\square$ Material didático para o Ensino Médio

$\square$ Material didático para o Ensino Superior

$\square$ Material paradidático

$\square$ Material da área de informática

$\square$ Material pedagógico

$\square$ Outros. Quais?

Que partes da Bibvirt você usa/ já usou? (escolha quantos itens quiser)

$\square$ Literatura

$\square$ Banco de Experiências

$\square$ Material Didático

$\square$ Mural de Recados

$\square$ Paradidáticos

$\square$ Gincana Cultural On-line

$\square$ Sons

$\square$ Links

$\square$ Imagens

$\square$ Busca

Que informação você está procurando na Bibvirt e para que você precisa dela?

Você a encontrou?

$\square \operatorname{Sim} \square$ Não 
Se sim, a informação que você pesquisou e achou na Bibvirt...

$\square$... continha exatamente os dados que você estava procurando.

$\square$... continha dados muito sofisticados.

... continha dados muito simples.

Se ela não era adequada as suas necessidades, explique por quê.

Se você já utilizou com sucesso a Bibvirt para pesquisa escolar ou como apoio em atividades educacionais (ensino ou aprendizagem), por favor conte-nos brevemente, mas com alguns detalhes, como foi seu uso.

Exemplo: "usei a Vozoteca para ilustrar, com os discursos em áudio, uma aula de História em que eu ensinei sobre o governo de Getúlio Vargas para alunos da $2^{\text {a }}$ série do Ensino Médio. A receptividade por parte dos alunos foi..."

Parte B: questões relativas ao estímulo dado pelo professor aos alunos para pesquisarem na Internet.

Se você é estudante ou professor, na sua escola existem computadores ligados à Internet para uso dos alunos? (se você não é estudante ou professor não responda) $\square \operatorname{Sim} \square$ Não

Se você é estudante, na sua escola os professores estimulam o uso da Internet para pesquisa? (se você não é estudante não responda).

$\square$ Sim, todos

$\square$ Alguns

$\square$ Nenhum 
Como ele faz essa orientação?

$\square$ Pede a pesquisa na Internet, mas não dá nenhuma referência.

$\square$ Pede a pesquisa na Internet, indicando alguns sites interessantes relacionados ao tema.

Vivencia o processo de busca de informação com você, fornecendo o endereço de alguns sites interessantes e estimulando a procura de outros relacionados ao tema.

2.4.4 Interactivity and User-Friendliness (Interatividade e Uso Amigável): Os usuários têm facilidade para buscar e recuperar informações na Bibvirt? Como é a interação com a equipe que desenvolve o site? A Bibvirt é interativa?

Antes de discutirmos as duas primeiras questões proponho a reflexão sobre uma questão que até hoje não está muito bem resolvida: a questão da interatividade em bibliotecas virtuais. Uma biblioteca virtual é ou não é interativa?

Para Machado (1997) ${ }^{54}$ a interatividade, hoje, é a possibilidade de responder ao sistema de expressão e de dialogar com ele por meio das novas ferramentas e suportes digitais oferecidos à nossa imaginação criadora e nosso espírito investigativo. Afirmação que faz sentido, se pensarmos que é possível requisitar uma informação ao sistema e receber um retorno como, por exemplo, quando visitamos a Bibvirt, entramos com uma palavra-chave e temos como retorno links para todas as informações contidas em seu acervo relacionadas ao tema.

Carlos Seabra, coordenador da Bibvirt, em entrevista feita por e-mail no dia 17.12.2001, completa esta idéia quando afirma:

"Interatividade depende mais do tipo de atividade e resposta que dá ao usuário do que ser on-line ou não. Para mim é um pressuposto, pois se você não faz uma biblioteca on-line ser interativa, não tem sentido fazê-la on-line. Se não for interativa não passa de um catálogo sem acesso e sem consultas inteligentes. A grande questão que se coloca aqui é saber se numa biblioteca online podemos apenas acessar a informação que ela possui, mas o acesso ao acervo só pode acontecer pessoalmente e fisicamente (ou por correio), ou se, ao

${ }^{54}$ MACHADO, Arlindo. Pré-cinemas e Pós-cinemas. Campinas-SP: Papirus, 1997. 
contrário, ela disponibiliza o acervo digitalmente (e aqui entra a importância de ser digital para possibilitar isto)".

Outro ponto de vista importante em relação à interatividade é o apresentado por Litto $^{55}$ (1996). Litto, neste texto, não questiona sobre a interatividade em ambientes virtuais, mas apresenta as principais vantagens da educação interativa onde podemos observar que uma biblioteca virtual, como por exemplo, a Bibvirt tem a possibilidade de oferecer estratégias que englobam muitas das atividades desta modalidade educacional. As vantagens relacionadas à educação interativa mencionadas por ele são apresentadas nos tópicos a seguir:

- Oferecer um novo ambiente para aprendizagem, em que o aluno é responsável pelo avanço do aumento do seu conhecimento e não o professor; o aluno prossegue na velocidade que mais conduz ao seu "estilo individual de aprendizagem" e pode explorar cantinhos escondidos informacionais sem ser intimidado por um adulto;

$\mathrm{Na}$ Bibvirt cada usuário navega e explora as informações contidas em seu acervo de acordo com suas necessidades e interesses, o que propicia o respeito ao ritmo de cada um, envolvendo-o no processo de busca e recuperação de informação.

- Oferecer um alto grau de envolvimento entre o aluno e o material a ser aprendido;

A possibilidade de acesso a informações em diferentes formatos, muitas delas em multimídia como, por exemplo, o som de aves brasileiras e as personalidades de nossa História em discursos significativos, levam a um alto grau de envolvimento por parte do educando.

- Ser personalizável, ou demassificável, podendo lembrar a configuração de talentos e gostos dos alunos e conduzi-lo a experimentar novidades e assim aumentar sua capacitação;

\footnotetext{
${ }^{55}$ LITTO, F. Repensando a educação em função de mudanças sociais e tecnologias recentes. In Vera Barros de Oliveira, org., Informática em Psicopedagogia. São Paulo: Senac, 1996. Pg. 85-110.
} 
Algumas das atividades presentes no site convidam o usuário a encarar desafios, como é o caso da Gincana Cultural On-line, onde o usuário participa junto com outros usuários de uma gincana de busca de informações na rede.

- Oferecer oportunidades ímpares para aumentar a auto-estima do aluno, que se sente no comando da sua navegação nos ambientes interativos.

Em ambientes virtuais o educando define seu processo de busca. Ele até pode ser orientado pelo seu professor para encontrar uma informação, mas com certeza, acabará encontrando outros caminhos para ter acesso a essa mesma informação, ou ainda, o acesso a essa informação, poderá levar ao acesso de outras informações novas que poderão ser novas não só para ele como para seus colegas, ou até mesmo para seu professor. E a oportunidade de troca de idéias com o grupo, com a possibilidade de apresentação das descobertas, levará a um aumento da auto-estima do aluno proveniente de uma educação interativa.

O último ponto que apresento para nossa discussão na tentativa de justificar a interatividade em bibliotecas virtuais é um trabalho desenvolvido em 1983 na França. Neste trabalho aparece a distinção de dois modelos de interatividade: "um nobre" referindo-se à comunicação instantânea e à distância entre pessoas. (de base elétrica), e outro definido como "diálogo homem-máquina" e referindo-se à escolha pelo usuário entre um leque de possibilidades pré-definidas pelo designer do programa (de base eletrônica). Neste contexto, Kretz (1983) ${ }^{56}$ também favorável a esta distinção, enumerou posteriormente seis gradações para o termo:

- Grau zero de interatividade. As únicas ações do usuário são de uma parte a interrupção do serviço, e de outra o acesso ao serviço ou a uma de suas aplicações (conteúdos). Ex: escolha de um canal de TV ou romance em uma biblioteca. Trata-se da interatividade de acesso.

\footnotetext{
${ }^{56}$ KRETZ, F. Dialogue, Service. Interactivité et Sés Composantes: aspects de conception et d'évaluation. Bulletin de L'IDATE. Paris: Centro Georges Pompidou, nº 11, abril, 1983. In: Silva, M. Sala de aula interativa. Rio de Janeiro: Editora Quartet. 2001. pg. 86
} 
- Interatividade linear. É o caso do romance dos discos e dos cassetes, desta vez folheados (seqüência, retorno, saltos a diante ou atrás, avanço ou retorno rápido). A consulta a listas em videografia (seqüência/retorno) pertence a essa categoria.

- Interatividade arborescente. A seleção se faz por escolha ou designação em um menu: videotexto arborescente, jornais ou revistas onde cada página tem uma dupla apresentação: de menu e de artigos, fotos, ...

- Interatividade lingüística. A que utiliza acesso por palavras-chave, formulário e até uma entrada de linguagem natural ou quase natural: videotexto, microcomputador.

- Interatividade de criação. Aquela que permite ao usuário compor uma mensagem textual, sonora, gráfica, mista, desenhos por correspondência e mensagens.

- Interatividade de comando contínuo. Permite a modificação, o deslocamento ou em geral a transformação de objetos sonoros ou visuais diretamente manipulados pelo usuário: videogames.

No item "interatividade de criação" eu acrescentaria a interatividade que acontece por meio dos novos meios de comunicação: e-mail, chat, fórum e lista de discussão, não apresentado por ele nesta classificação, devido à época em que foi elaborada. Todas essas ferramentas disponíveis na rede Internet permitem ao usuário compor uma mensagem textual e transmiti-la a outras pessoas individualmente ou em grupo de forma síncrona ou mesmo assíncrona.

Com isso, diante da afirmação apresentada por Machado "o dado novo é a interatividade, a possibilidade de responder ao sistema de expressão e de dialogar com ele", da definição feita por Kretz para a interatividade lingüística "A que utiliza acesso por palavras-chave, formulário e até uma entrada de linguagem natural ou quase natural: videotexto, microcomputador", e as principais vantagens da Educação 
Interativa apresentada por Litto em 1996, pode-se afirmar que a Bibvirt assim como as demais bibliotecas virtuais são interativas, pois:

- Há diálogo entre o usuário e o ambiente que a partir do momento que o usuário fornece palavras-chave recebe como resultado uma informação para sua pesquisa.

- O usuário navega de acordo com suas necessidades, visitando links sem a necessidade de uma seqüência pré-definida.

- O usuário é responsável pelo seu processo de ensino-aprendizagem, onde ele define se há ou não a necessidade de mais informações.

- O usuário é quem determina o momento que deve avançar na procura de novas informações.

Com a intenção de melhorar a interação dos usuários com a Bibvirt, seguimos as orientações dadas por Dervin (1983) ${ }^{57}$, onde por meio da abordagem Sense-Making, percebe-se que qualquer tentativa de descrever padrões de busca de informação deve admitir o indivíduo como o centro do fenômeno e considerar a visão, necessidades, opiniões e dificuldades desse indivíduo como elementos significantes e influentes que merecem investigação.

Para fazer uma análise minuciosa do processo de busca e recuperação de informações, presentes na interatividade do usuário com a Bibvirt, dividiu-se esse tópico em três partes: Parte A - levantamento de dados para análise do processo de busca de informação, Parte B - levantamento de dados para análise do processo de recuperação de informações e Parte $\mathbf{C}$ - interatividade com a equipe da Bibvirt.

${ }^{57}$ DERVIN, B. An overview of Sense-Making research: concepts, methods and results to date. (On line) In: International Communications Association's Annual Meeting. Dallas, May, 1983. Available from www, <URL: http:// www.eca.usp.br/prof/sueli/sm1983 4.html> 
Parte A: Busca de informação

Para que você mais usa a Bibvirt?

$\square$ Estudo/pesquisa

$\square$ Lazer

$\square$ Trabalho

$\square$ Outros

Você consegue localizar facilmente as informações no acervo da Bibvirt?

$\square$ Sempre

$\square$ Quase sempre

$\square$ Às vezes

$\square$ Raramente

$\square$ Nunca

Qual foi o caminho que você fez para localizar a informação que estava procurando? Ex: Vamos supor que você estivesse procurando informações sobre aves brasileiras. Você pode ter feito o seguinte caminho: link busca, colocado a palavra-chave "aves brasileiras" e depois clicado no link "banco de imagens - aves do Brasil".

Descreva, de maneira sucinta, qual foi a dificuldade que encontrou na busca da informação procurada.

Parte B: Recuperação de Informação

Quando você acha o material de pesquisa, tem facilidade para ler o seu conteúdo? $\square \operatorname{Sim}$

$\square$ Não

Se você tem dificuldade descreva por quê. 
Como você utiliza os livros existentes na seção de Literatura? (marque quantos itens quiser):

$\square$ Leio na tela do micro.

$\square$ Imprimo direto da Internet.

$\square$ Faço download e depois leio na tela do micro.

$\square$ Faço download e depois imprimo.

$\square$ Leio em um "palmtop" ou outro micro de mão.

$\square$ Outros:

Marque apenas um item:

$\square$ Costumo ler o livro todo.

$\square$ Não costumo ler o livro todo.

Parte C: Interatividade com a equipe da Bibvirt.

Alguma vez você requisitou ajuda da Bibvirt para tirar dúvidas?

$\square \operatorname{Sim}$

$\square$ Não

Se sim, conseguiu resolvê-la?

$\square \operatorname{Sim}$

$\square$ Não

Se sim, esta informação acrescentou algo novo nos seus conhecimentos de informática?

$\square$ Sim

$\square$ Não

O que mais você gostaria que tivesse no site da Bibvirt? 
2.4.5 Organizational Issues (Assuntos Organizacionais): Que mudanças devem ser feitas para melhor atender ao usuário?

Nos itens anteriores Interatividade/Uso Amigável e Funções de Aprendizagem já foram abordadas questões que permitem avaliar o processo de busca e recuperação de informações feitas pelos usuários no site da Bibvirt.

Neste item, a intenção é conhecer a opinião do usuário, ou seja, avaliar a forma como ele procura informação e como acha que um sistema pode ser melhor projetado a fim de atender às suas necessidades.

Como apresentado por Dervin (1986), na abordagem Sense-Making, deve-se levar em consideração a individualidade (usuários devem ser tratados como indivíduos e não como conjunto de atributos demográficos) para definir padrões (analisando as características individuais de cada usuário, chega-se aos processos cognitivos comuns à maioria). Sendo assim, as questões colocadas no questionário foram:

Qual informação você gostaria de encontrar no site da Bibvirt?

O que você acha que poderíamos fazer para facilitar a localização das informações no acervo?

2.4.6 Novelty (Originalidade): Quanto a Bibvirt é realmente inovadora?

Para responder a essa questão foi feita uma pesquisa na Internet para levantamento de outros sites voltados à mesma finalidade proposta pela Bibvirt (ver Anexo 4). Também foi perguntado ao usuário "qual a possibilidade de encontrar o material do acervo em outras mídias", como podemos ver a seguir: 
O material que você pesquisou e achou na Bibvirt, seria de fácil acesso em outra fonte de pesquisa, tais como livros, revistas, jornais, cd-roms, etc.?

$\square$ Sempre

$\square$ Quase sempre

$\square$ Às vezes

$\square$ Raramente

$\square$ Nunca

2.4.7 Speed (Velocidade): Como é a velocidade de acesso a Bibvirt para o usuário?

As possibilidades oferecidas para o desenvolvimento de sites hoje, muitas vezes não correspondem à realidade do usuário. Dependendo dos recursos utilizados para seu desenvolvimento, o acesso tornar-se lento para usuários conectados a baixa velocidade.

O objetivo desse item é analisar como os usuários, de um modo geral, sentem sua navegação pelo site para, se for o caso, repensar os recursos que são utilizados na sua construção.

Normalmente, como é a velocidade de acesso ao site da Bibvirt?

$\square$ Muito rápida

$\square$ Rápida

$\square$ Normal

$\square$ Lenta

$\square$ Muito lenta

Com esse tópico encerram-se as questões que compõem a análise. Depois disso, o questionário foi colocado na Bibvirt onde ficou hospedado durante seis meses (01 de setembro de 2000 até 25 de fevereiro de 2001).

Recebi 528 questionários respondidos por usuários da Bibvirt. Desses, 49 foram considerados inválidos por estarem incompletos ou repetidos (o usuário enviou duas vezes o mesmo), restando 479 questionários válidos. 
Os dados foram tabulados, com o auxílio do software Excel ${ }^{\circledR}$. Alguns gráficos foram apresentados em forma de setor e outros através de barras verticais, dependendo do tipo de dado a ser avaliado.

As questões abertas foram agrupadas por familiaridade. Elas não representam o perfil do usuário, mas contribuem para detectar as necessidades e dificuldades encontradas pelos usuários em uma visita a Bibvirt.

Como isso, fecha-se esse capítulo que inicia apresentando a base filosófica do modelo "Actions" desenvolvido por Bates e a abordagem "Sense-Making" desenvolvida por Dervin. O modelo "Actions", por meio da sigla ACTIONS permite uma análise detalhada para decisão da melhor ferramenta a ser utilizada para a função de aprendizagem a distância que se deseja oferecer.

A abordagem "Sense-Making" trás um novo paradigma para análises de processos de busca de informação sugerindo que o enfoque recaia sobre o usuário e não no sistema. Essa abordagem apresenta haver a necessidade de se levar em consideração os processos individuais para definição de padrões; os movimentos considerados únicos para cada realidade de tempo e espaço; e o uso que o usuário fará da informação que auxiliará na resolução de algum problema, suprindo a lacuna inicial.

O questionário colocado no site da Bibvirt foi elaborado a partir do entrelaçamento destas duas metodologias. Definiu-se que o modelo "Actions" seria o fio condutor, por abordar questões centrais que permitem traçar a identidade do usuário da Bibvirt e a abordagem Sense-Making seria utilizada para definir questões mais específicas relacionadas aos itens Interatividade/Uso Amigável e Aspectos Organizacionais, que permitem aprofundar a análise no processo de busca e recuperação de informações.

No decorrer da elaboração do questionário surgiu a necessidade de se aprofundar na discussão sobre a interatividade em bibliotecas virtuais. Algumas fontes foram consultadas e pela análise feita por Machado (1997), Kretz (1983), Litto (1996) e 
Seabra (2001), podemos dizer que as bibliotecas virtuais são espaços interativos pois:

- Há diálogo entre o usuário e o ambiente que a partir do momento que o usuário fornece palavras-chave recebe como resultado uma informação para sua pesquisa.

- O usuário navega de acordo com suas necessidades, visitando links sem a necessidade de uma seqüência pré-definida.

- O usuário é responsável pelo seu processo de ensino-aprendizagem, onde ele define se há ou não a necessidade de mais informações.

- O usuário é quem determina o momento que deve avançar na procura de novas informações.

No próximo capítulo será feita uma análise detalhada dos resultados coletados a partir da pesquisa colocada no site da Bibvirt, vindo confirmar a missão e os objetivos propostos no sumário executivo original (ver Anexo 2). 


\title{
CAPÍTULO 3
}

\section{Resultados da Pesquisa}

\author{
Mude, \\ mas comece devagar, \\ porque a direção é mais importante \\ que a velocidade.
}

Mude, de novo.

Experimente outra vez.

Você certamente conhecerá coisas melhores

e coisas piores do que as já conhecidas, mas não é isso o que importa. O mais importante é a mudança,

o movimento, o dinamismo, a energia.

Só o que está morto não muda! 


\section{Análise dos Dados}

De acordo com a proposta desta dissertação, a pesquisa teve como objetivo desvendar o perfil dos usuários da Bibvirt, dando maior ênfase as possibilidades e aos limites no processo de busca e recuperação de informações no seu acervo, com o intuito de fornecer subsídios à equipe da Bibvirt para que ela possa reestruturar o site e melhorar a navegação para o usuário.

Obviamente, este estudo não pretendeu ser um fim em si mesmo, uma vez que as inevitáveis limitações de um trabalho acadêmico deste porte resultaram em recortes e enfoques direcionados. Sendo assim, as considerações apresentadas têm por objetivo promover a discussão e instigar outros pesquisadores a explorar continuamente as diversas facetas do tema abordado.

Para facilitar a leitura e interpretação dos dados, dividi a análise em quatro partes, com a finalidade de conhecer:

* Quem é o usuário da Bibvirt?

* Quais são as funções de aprendizagem relacionadas à Bibvirt, apresentadas pelo usuário?

* Como é seu processo de busca de informação no site?

* Como ele recupera informação? 


\subsection{Perfil dos Usuários da Bibvirt}

A Internet cresce rapidamente no Brasil. Considerando a pesquisa feita pela Datafolha e apresentada na revista da Folha de São Paulo (27/09/2001) como sendo a mais representativa, percebemos que a cada ano mais pessoas fazem parte dessa comunidade virtual. A Datafolha afirma que hoje temos, no Brasil, 23 milhões de pessoas conectadas (19\% da população), um aumento significativo em relação à anos anteriores. Pela $2^{a}$ pesquisa feita pelo Instituto InternetPop ${ }^{58}$, em julho de 1998 éramos $6 \%$ da população conectada à Internet, sendo que $86 \%$ pertenciam a classe A ou B. Se compararmos os dois dados, podemos perceber que de julho de 1998 à setembro de 2001 o acesso à Internet cresceu $316,66 \%$.

O acesso a Bibvirt tem acompanhado essa evolução. Nos dois últimos anos, o número de acessos ao site cresceu de uma média de 1053 usuários por dia, em fevereiro de 1999, para uma média de 5140 usuários por dia, em agosto de 2001, um aumento de $488,13 \%$ em 2,5 anos.

\footnotetext{
${ }^{58}$ Intituto InternetPop. O perfil da Internet Brasileira. ${ }^{\text {a }}$ Pesquisa - 1998. Available from Internet $<$ http://www.ibope.com.br/digital/produtos/internetpop/index.htm> [14.01.2002]
} 
$\mathrm{Na}$ análise dos gráficos podemos perceber que a grande maioria dos usuários da Bibvirt tem idade entre 14 e 17 anos (20,9\%), mas também encontramos porcentagens significativas de usuários com idade entre 30 e 39 anos (18,3\%), entre 18 e 21 anos $(17,4 \%)$ e entre 22 e 25 anos (15,1\%). Na revista da Folha de São Paulo de 27 de setembro de 2001 (Pg. 10) temos que 57\% dos internautas no Brasil têm idade entre 14 e 24 anos. Se somarmos as três classes que representam essa faixa etária na pesquisa colocada na Bibvirt, teremos um total de $53 \%$ dos usuários da Bibvirt como pertencendo a esta faixa etária o que confirma a participação massiva do jovem na Internet. Ver gráfico 3.1.1.

\section{Idade dos Usuários da Bibvirt}

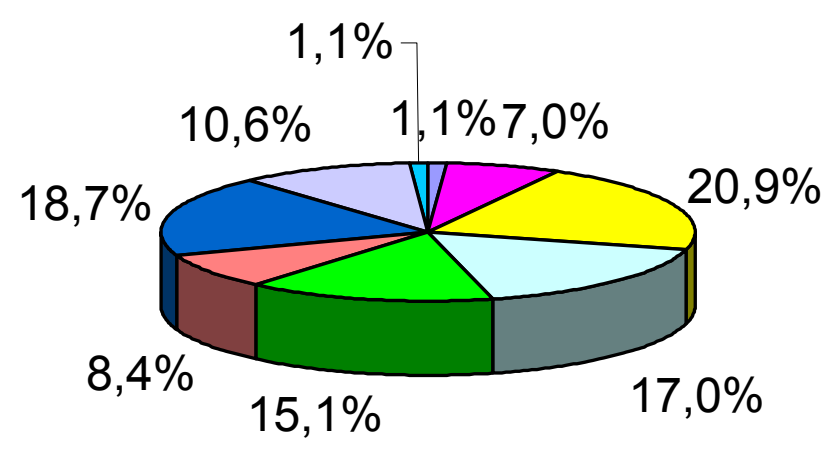

$\square$ abaixo de 9 anos
$\square$ de 10 a 13 anos
$\square$ de 14 a 17 anos
$\square$ de 18 a 21 anos
$\square$ de 22 a 25 anos
$\square$ de 26 a 29 anos
$\square$ de 30 a 39 anos
$\square$ de 40 a 55 anos
$\square$ mais de 56 anos

Gráfico 3.1.1 
A pesquisa mostra ainda que $37,8 \%$ de seus usuários são estudantes do ensino fundamental I, II e médio, permitindo afirmar que a Bibvirt atende ao público-alvo a que se destina. Mas, além desses estudantes também temos uma porcentagem significativa de estudantes universitários que acessam o site $(23,8 \%)$, pois o acervo da Bibvirt não se restringe a informações para alunos de ensino fundamental e médio. Todas as obras literárias em Língua Portuguesa disponiblizadas no site, bem como o banco de sons de aves e instrumentos musicais brasileiros, de vozes de personalidades de nossa História em discursos importantes e diversas outras informações podem interessar a qualquer pessoa. Ver gráfico 3.1.2.

\section{Atividade Principal do Usuário}

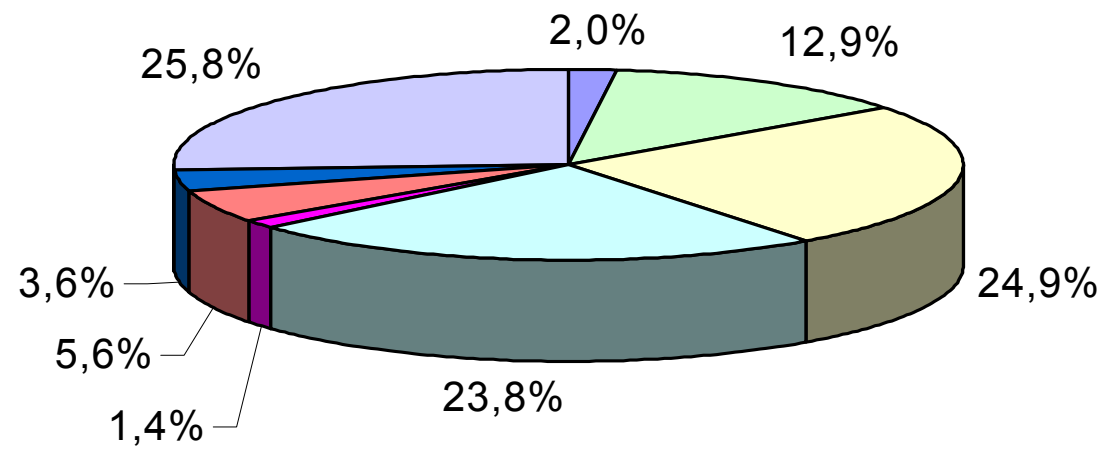


A participação feminina na Internet cresceu bastante nos últimos anos. Hoje, 42\% dos internautas são do sexo feminino (dado apresentado na Revista da Folha de São Paulo em 27.09.2001). Na Bibvirt não é diferente. O número de acessos femininos é quase que equiparado ao número de acessos masculino - 50,7\% (masculino) contra 49,3\% (feminino). Ver gráfico 3.1.3

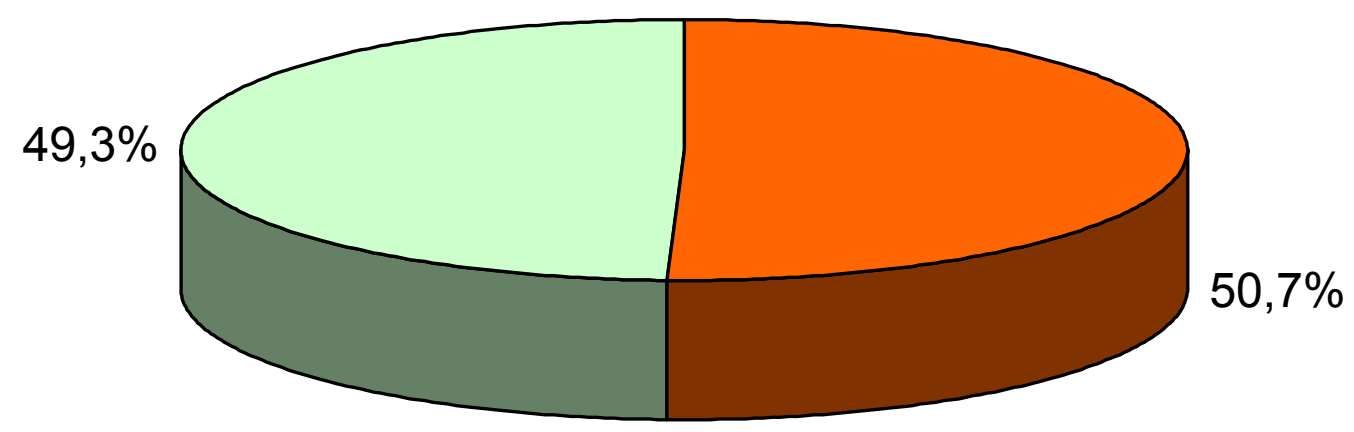

$\square$ Masculino $\square$ Feminino

Gráfico 3.1.3 
Um dos objetivos da Bibvirt, apresentado em seu sumário executivo original (ver Anexo 1), é ajudar a reduzir o isolamento das áreas rurais e pequenas comunidades em todo Brasil. Pela pesquisa colocada no site podemos ver que a maioria dos usuários mora no Estado de São Paulo (44\% dos entrevistados), mas quando analisamos por região brasileira percebemos que a região Nordeste e a região Sul também compõem uma porcentagem significativa expressa por $13 \%$ na região Nordeste e $12,1 \%$ na região Sul. Ver gráficos 3.1 .4 e 3.1.5.

\section{Onde o Usuário Mora?}

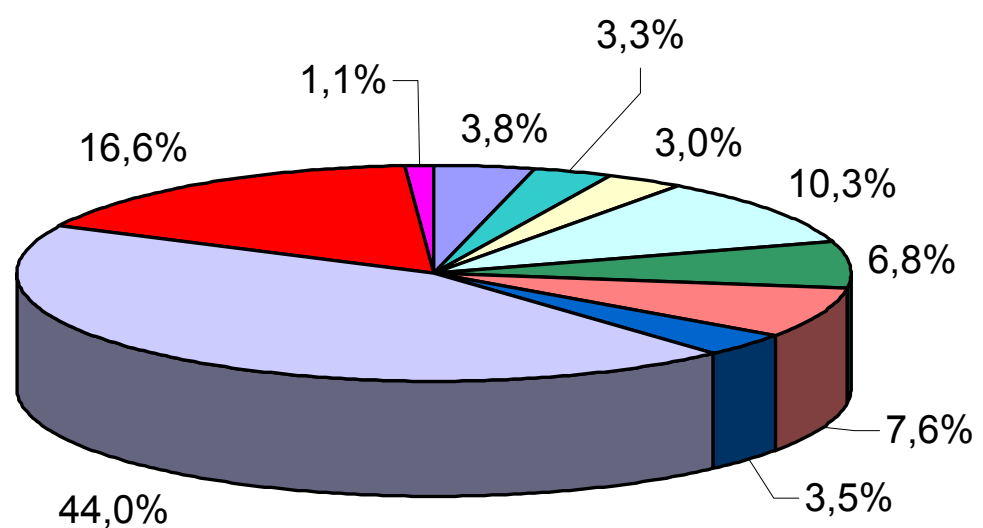

\begin{tabular}{|lcll|}
\hline$\square \mathrm{BA}$ & $\square \mathrm{CE}$ & $\square \mathrm{DF}$ & $\square \mathrm{MG}$ \\
$\square \mathrm{PR}$ & $\square \mathrm{RJ}$ & $\square \mathrm{RS}$ & $\square \mathrm{SP}$ \\
$\square$ Outros Estados & $\square$ Outros Países & & \\
\hline
\end{tabular}

Gráfico 3.1.4

Região Brasileira Onde Mora o Usuário.

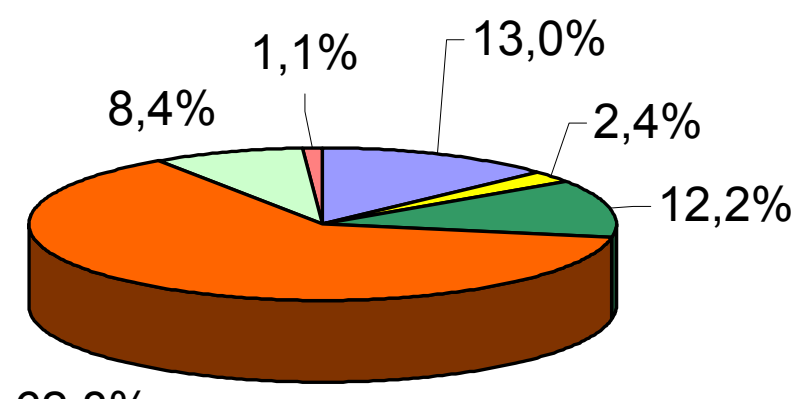

$62,8 \%$

Gráfico 3.1.5 
A análise desses dados, somada ao fato de que o número de usuários da Bibvirt que moram em capitais brasileiras $(50,8 \%)$ é praticamente o mesmo do que o número de usuários da Bibvirt que moram no interior (49,2\%), atingindo inclusive um número significativo de usuários que moram em vilarejos com até 10.000 habitantes $(7 \%)$, permite afirmar que a Bibvirt está ajudando a diminuir o isolamento de áreas rurais e pequenas comunidades em todo o Brasil a partir do momento que oferece oportunidade de acesso gratuito aos usuários, estejam eles onde estiverem. Ver gráficos 3.1.6 e 3.1.7.

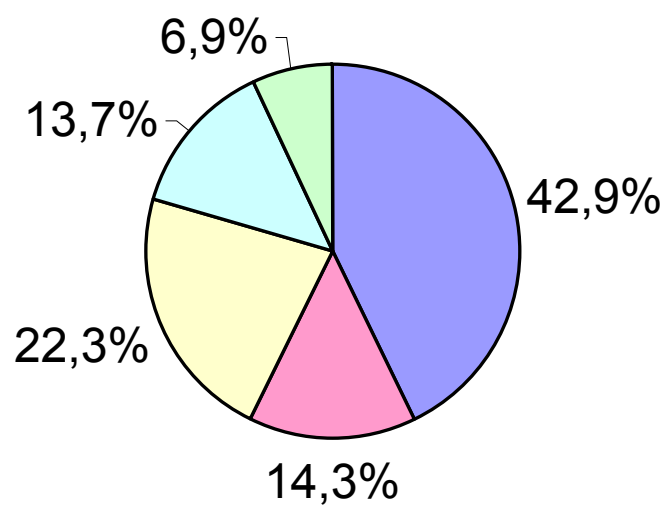

$\square$ Cidades com mais de 1 milhão de habitantes

$\square$ Cidades com mais de 500.000 habitantes

$\square$ Cidades com menos de 500.000 e mais de 100.000 habitantes

$\square$ Cidades com menos de 100.000 habitantes

$\square$ Vilarejos até 10.000 habitantes

Gráfico 3.1.6

\section{Relação Capitais X Interior}

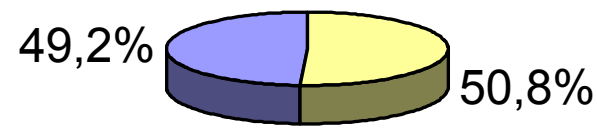

$\square$ Capital $\square$ Interior

Gráfico 3.1.7 
A partir dos dados apresentados na pesquisa, podemos perceber que a Bibvirt pode tornar-se cada vez mais importante no cenário nacional, pois a não ser nas grandes metrópoles o acesso à informação ainda é restrito na maioria das regiões brasileiras, apesar de haverem algumas iniciativas com o intuito de popularizar o acesso à informação. Uma destas iniciativas é coordenada pelo Ministério da Cultura que desde 1996 executa o programa "Uma biblioteca em cada município". Como podemos ver no Livro Verde ${ }^{59}$, organizado pela Sociedade da Informação Brasileira, esse programa visa implantar bibliotecas em municípios desprovidos. A ação é sempre conveniada com municípios (ou Estados), cabendo à parte local fornecer instalação física, conexão telefônica e funcionários, bem como formalizar, por lei, a existência da biblioteca. De 1996 a 1999 foram implantadas 687 novas bibliotecas. O objetivo do programa, como apresentado no edital com as informações básicas que está disponível no site do Ministério da Cultura (http://www.minc.gov.br/), é "promover o crescimento da rede atual de bibliotecas públicas, a fim de estimular a formação de leitores como uma condição básica de exercício de cidadania".

Esse objetivo é muito ambicioso se levarmos em consideração o acervo "pobre" que é colocado à disposição da população local e a orientação que recebem para acesso às informações que não acontece, muitas vezes, por meio de um especialista da área de biblioteconomia, apesar de no edital do programa estar imposta essa exigência. Esse fato pode prejudicar além dos aspectos gerencial e administrativo para organização e difusão da informação à comunidade, o aspecto de aquisição de conhecimento, podendo a biblioteca passar a ser um mero entreposto entre o produtor de informação e o destinatário, onde não há troca de idéias.

Em relação ao acervo, podemos ver, no edital com informações básicas sobre o programa que o acervo máximo que pode ser disponibilizado, para cada biblioteca, é de 2600 livros composto por:

* Uma enciclopédia Barsa.

* Dicionários e obras de referência para estudantes e professores.

* Literatura infanto-juvenil.

\footnotetext{
${ }^{59}$ TAKAHASHI, T. Sociedade da Informação no Brasil. Livro Verde. Brasília: Ministério da Ciência e Tecnologia, 2000. p. 64.
} 
* Paradidáticos de vários tipos.

* Literatura adulta nacional e internacional, tanto clássica quanto recreativa.

* Obras úteis para a saúde, a família, a mulher, a comunidade, a terceira idade e a cultura geral.

Se levarmos em consideração as idéias de Perrotti ${ }^{60}(2001)$ onde a nova visão de biblioteca é que ela deva ser interativa, instalada em um espaço "dinâmico" onde há relações em um movimento permanente, tendo oportunidade de ter acesso a todas as formas de informação que circulam na sociedade (escrita, oral, audiovisual, multimídia), não podemos pensar que um espaço contendo somente 2600 títulos possa ser considerado uma biblioteca.

Ainda segundo Perrotti, uma biblioteca tem que considerar história, recursos, interesses e expectativas locais, que devem dialogar com interesses gerais do País, não cabendo mais a criação de ambientes em um único formato e muito menos a criação de ambientes isolados. "As bibliotecas devem estar em rede e cada um destes espaços deve contar com a presença de um bibliotecário apto a buscar informações em ambientes virtuais".

O programa "Uma biblioteca em cada município" do Ministério da Cultura é exatamente contrário a essa nova visão. No edital com as informações básicas dessa proposta podemos perceber que a idéia é padrão para qualquer prefeitura interessada em participar do programa, a começar pelo acervo que é restrito a uma lista de livros pré-selecionados.

Em relação à informatização destes espaços, pelo edital podemos ver que cada uma das novas bibliotecas está automaticamente inscrita no "Programa de informatização das Bibliotecas Públicas", que irá acontecer em parceria com o programa "Sociedade da informação" (sediado no Ministério da Ciência e Tecnologia), o Ministério das Telecomunicações, o Fundo de Universalização das Telecomunicações (FUST), a Comunidade Solidária, o Ministério da Cultura e a Biblioteca Nacional.

\footnotetext{
${ }^{60}$ PERROTTI, E. Biblioteca interativa. Revista "Conselho Federal de Biblioteconomia" $n^{\circ} 1$ de abril de 2001. Available from Internet <URL:http://www.cfb.org.br/atualizacao/basica.htm >. [14.01.2002]
} 
A julgar pelos parceiros e o envolvimento deles em outros programas de informatização que já tive oportunidade de mencionar anteriormente, a viabilização deste programa não acontecerá tão cedo. No entanto, quando isso acontecer ampliará a oportunidade de acesso a produtos e serviços já disponíveis na rede, dentre eles a Biblioteca Virtual do Estudante Brasileiro, auxiliando desta forma a suprir a escassez de informações em pequenas comunidades por todo Brasil.

Por coincidência, enquanto esta dissertação estava sendo redigida (dezembro de 2001), saiu uma notícia no site do Boletim Eletrônico do Governo Federal ${ }^{61}$ falando exatamente sobre essa questão e confirmando idéias anteriores. A notícia informa sobre um novo programa do governo, que tem lançamento previsto para este ano, onde haverá um processo de seleção e implementação de bibliotecas escolares, instituições públicas ou mesmo acervos de organizações da sociedade civil considerados de interesse público para serem incluídos dentro de uma rede virtual, com seu conteúdo oferecido através do acesso on-line via Internet.

${ }^{61}{ }_{11}$ Boletim Informativo do Governo Eletrônico. Programa permitirá acesso ao conteúdo de bibliotecas de todo o País. Brasília, 13 a 20 de dezembro de 2001. Available from Internet <URL: http://www.governoeletronico.gov.br/noticias.cfm?id noticias=511> [16.12.2001] 
Ainda em relação ao perfil dos usuários da Bibvirt, por meio dos resultados da pesquisa colocada no site, podemos ver que os usuários que acessam a Bibvirt compõem parcelas iguais das mais diferentes classes sociais (Ver gráfico 3.1.8), o que nos surpreende, pois se observarmos a pesquisa que foi feita pelo lbope www.eRatings.com, que representa o serviço Nielsen/ NetRatings na América Latina, constatamos que a utilização da Internet no Brasil continua crescendo, mas a classe $\mathrm{A}$, como apresentado por eles, ainda representa quase $50 \%$ dos usuários.

\section{Média da Renda Familiar}

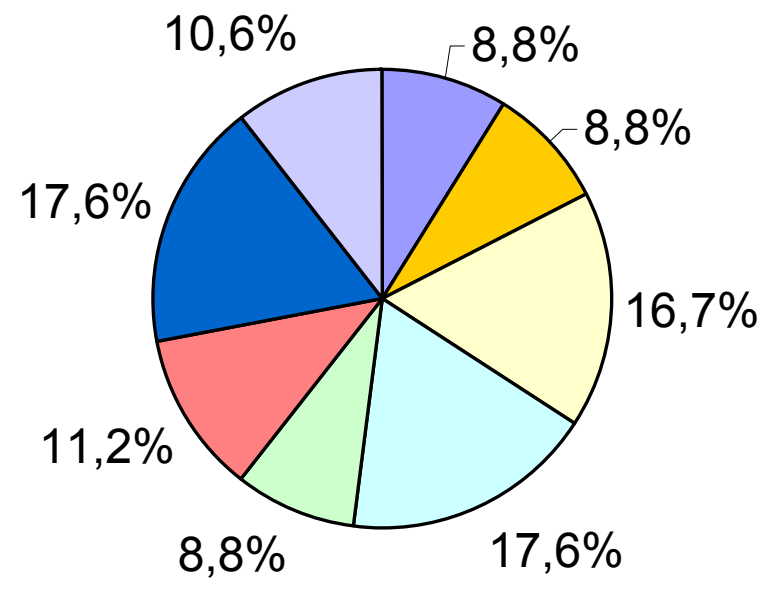

$\begin{array}{ll}\square \text { até } R \$ 300,00 & \square \text { de } R \$ 301,00 \text { a } R \$ 600,00 \\ \square \text { de } R \$ 601,00 \text { a } R \$ 1.200,00 & \square \text { de } R \$ 1.201,00 \text { a } R \$ 3.000,00 \\ \square \text { de } R \$ 3.001,00 \text { a } R \$ 6.000,00 & \square \text { de } R \$ 6.001,00 \text { a } R \$ 10.000,00 \\ \square \text { de } R \$ 10.001,00 \text { a } R \$ 20.000,00 & \square \text { mais de } R \$ 20.001,00\end{array}$

Gráfico 3.1.8

Seria interessante, em um próximo momento investigar, com mais detalhes, o perfil econômico dos usuários da Bibvirt, e comparar com o perfil econômico dos usuários da Internet. Nesta pesquisa, os dados apresentados não foram suficientes para essa análise. 
Os outros dados apresentados na pesquisa sobre o perfil dos usuários da Bibvirt são relacionados ao tipo de instituição que os estudantes freqüentam e de onde eles fazem o acesso à Internet. Os resultados nos mostram que $49,3 \%$ dos estudantes que responderam à pesquisa são de escolas particulares e $50,7 \%$ de escolas públicas, o que não significa que há uma diminuição no número de pessoas excluídas do mundo digital, pois por meio de outro gráfico observamos que $72,1 \%$ dos estudantes acessam à Internet de casa. Ver gráficos 3.1.9 e 3.1.10.

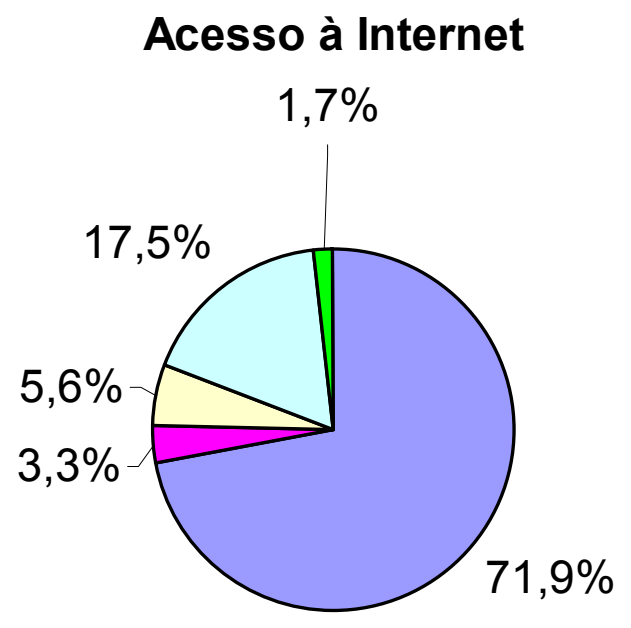

\begin{tabular}{|ll|}
$\square$ em casa & $\square$ na casa de amigos/parentes \\
$\square$ na escola/universidade & $\square$ no trabalho \\
$\square$ na biblioteca & \\
\hline
\end{tabular}

Gráfico 3.1.9

Tipo de Escola

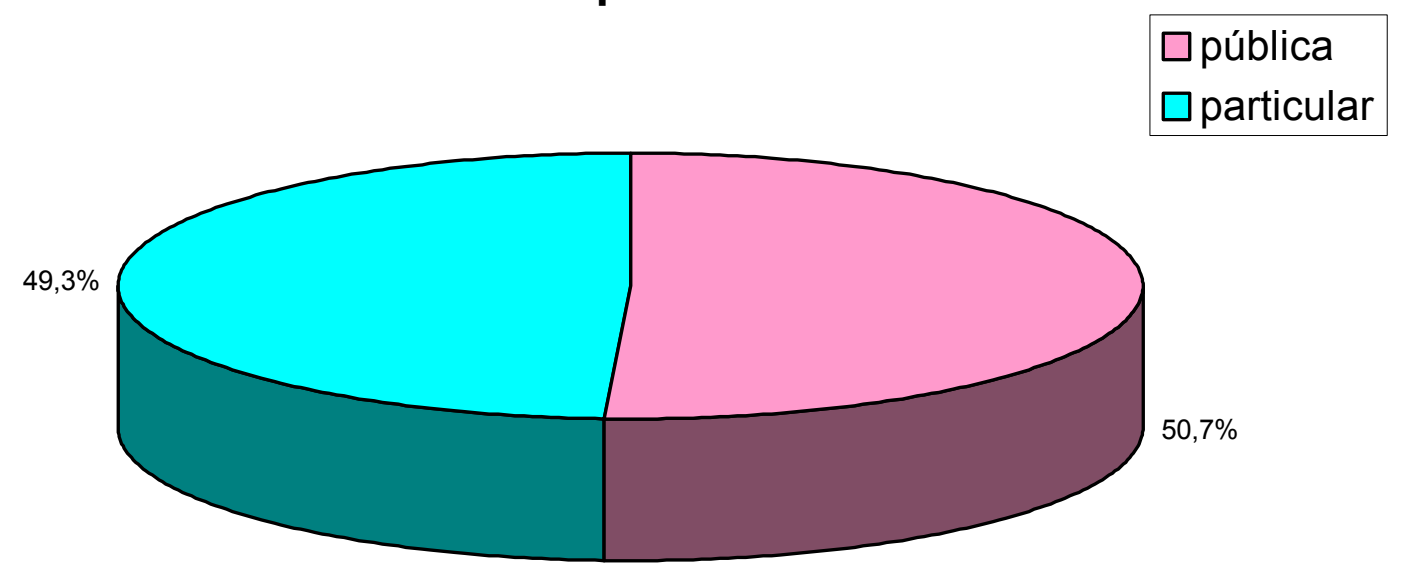

Gráfico 3.1.10 
Em muitos textos relacionados ao uso dos computadores na Educação podemos encontrar discussões sobre a ociosidade dos laboratórios de informática presentes tanto em escolas públicas quanto particulares. A justificativa é a falta de preparo e de interesse de muitos professores em inserir recursos tecnológicos na sua prática pedagógica diária. Essa circunstância pode refletir na formação de muitos estudantes para a sociedade da informação no Brasil que têm oportunidade de acesso à Internet somente em computadores da escola, gerando um atraso no desenvolvimento da nossa sociedade.

O foco maior da Bibvirt concentra-se no acervo literário, com a disponibilização cada vez maior de importantes obras clássicas da literatura brasileira e também de algumas publicações da literatura estrangeira. Todo o trabalho para publicação acontece com o apoio de voluntários que digitam e fazem a revisão do material que será publicado na Bibvirt (ver Anexo 5). Com isso na maior parte dos acessos $(84 \%)$ os usuários desenvolvem atividades relacionadas a estudo/pesquisa, demonstrando que a procura maior é pelo acervo literário e material didático. Ver gráficos 3.1.11 e 3.1.12.

\section{Partes mais Utilizadas da Bibvirt}

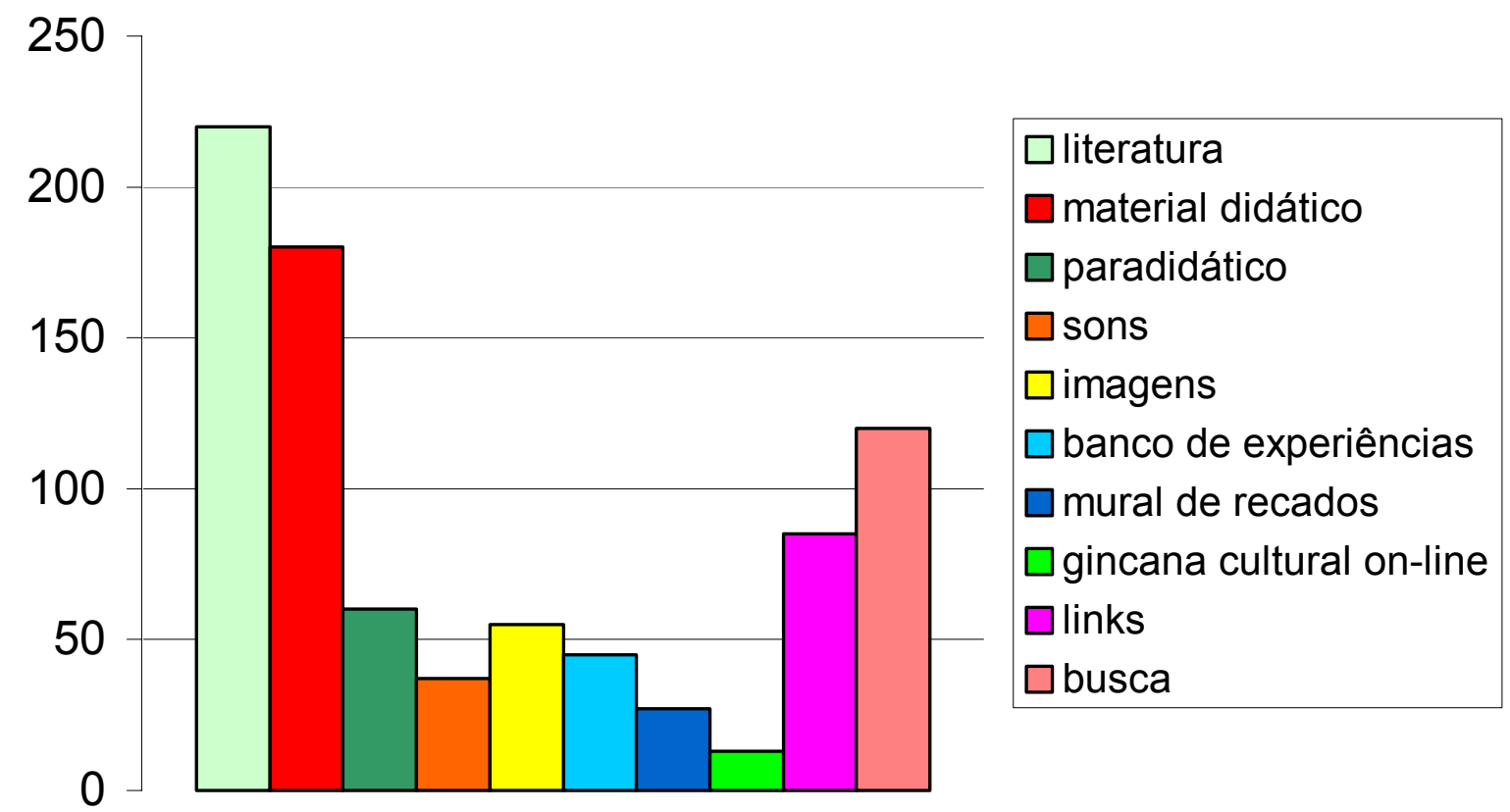

Gráfico 3.1.11 


\section{Uso da Biblioteca Virtual (Bibvirt)}

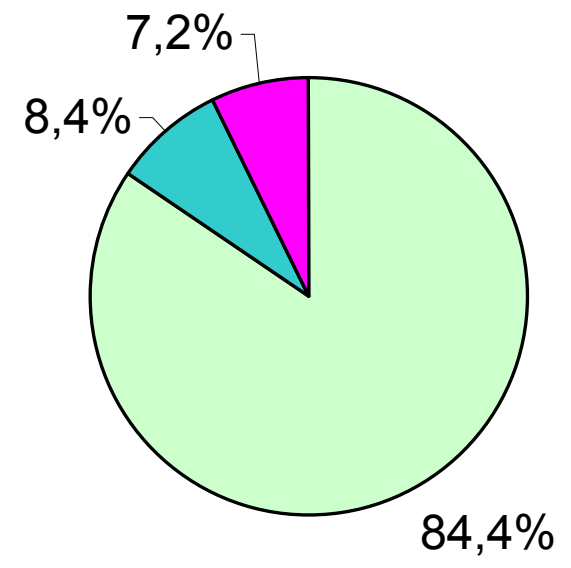

Gráfico 3.1.12

Este resultado é importante, pois em muitas regiões brasileiras é difícil o acesso a livros de qualquer gênero devido ao baixo número de bibliotecas e livrarias ${ }^{62}$ (1200 em todo Brasil). Para uma população de aproximadamente 170 milhões de habitantes como é a nossa, o número ideal de livrarias deveria ser de pelo menos $17.000 \mathrm{e}$, no entanto, temos somente 1.200 sendo que a maioria delas está instalada na região Sul e Sudeste.

${ }^{62}$ COPRANI, O. Livro, Biblioteca e Leitura no Brasil. Brasília: 1998. Available from Internet <URL: http://www.minc.gov.br > [15.01.2002] 
Em relação ao software utilizado para navegação na Internet, a maior parte dos usuários da Bibvirt (48,5\%) dá preferência ao Explorer 5.x, permitindo que a velocidade de navegação seja normal, como apresentado por $44,6 \%$ dos usuários, e rápida para alguns $(39,8 \%)$.

Ver gráficos 3.1 .13 e 3.1.14

Tipo de Navegador

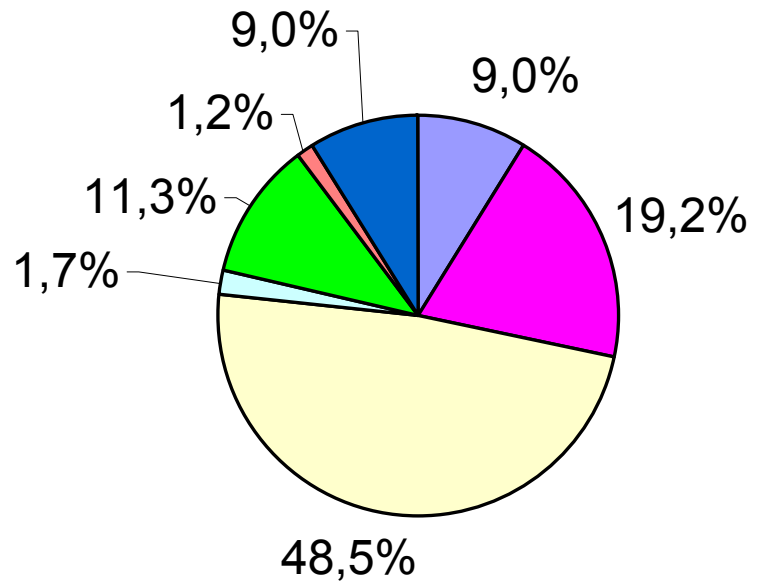

$\square$ Explorer 3.x

$\square$ Explorer 4.x

$\square$ Explorer $5 . x$

$\square$ Netscape 3.x

$\square$ Netscape 4.x

$\square$ Netscape $5 . x$

$\square$ Outros

Gráfico 3.1 .13

\section{Velocidade de Navegação}

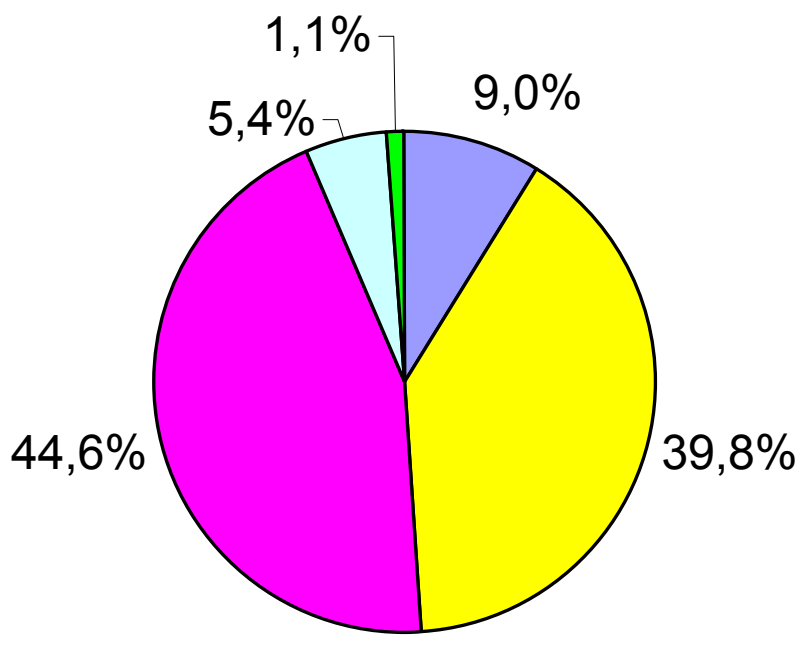

$\square$ muito rápida

$\square$ rápida

$\square$ normal

$\square$ lenta

$\square$ muito lenta

Gráfico 3.1.14 
Também foi perguntado aos usuários se a informação encontrada na Bibvirt seria fácil de encontrar em outras fontes. A maior parte dos usuários (36,9\%) disse que, possivelmente encontraria a informação em outros meios, mas muitos recursos, como os discursos históricos gravados de personalidades da nossa História e o banco de sons de pássaros e instrumentos brasileiros, dificilmente seriam encontrados em outros meios, o que é reconhecido por $13,6 \%$ dos usuários que responderam ser raro encontrar a informação em outras mídias. Ver gráfico 3.1.15

\section{Facilidade de Acesso às Informações em Outros Meios}

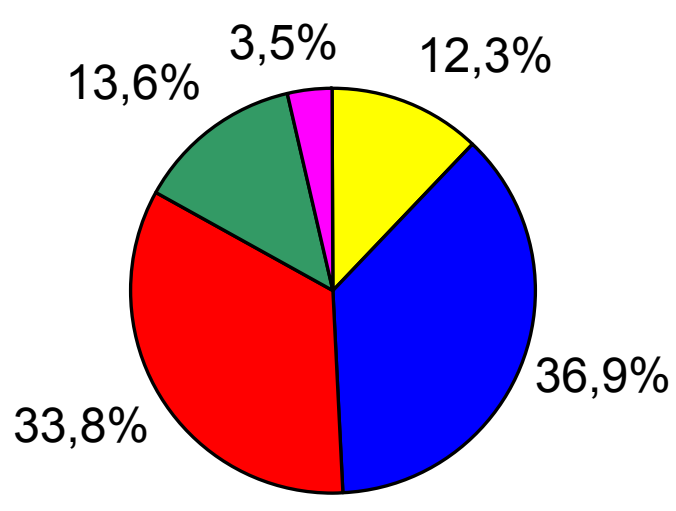

Gráfico 3.1.15

\section{$\square$ sempre $\square$ quase sempre $\square$ às vezes $\square$ raramente $\square$ nunca}

O espaço virtual é infinito, mas a liberação dos direitos autorais para publicação na Internet tem sido o grande entrave encontrado pela Bibvirt. Como apresentado por Litto $^{63}$ em uma palestra para ABED - Associação Brasileira de Ensino a Distância (2001), “Hoje a capacidade é cada vez maior para armazenar informação e conhecimento de todos os tipos (textos, imagens estáticas, imagens animadas, gráficos e som multi-canal...), transferir informação e conhecimento através de grandes distâncias, além de duplicar cópias imediatas, iguais e prolíficas em diferentes suportes". Nesta mesma palestra, Litto comenta sobre a "base legal" e os "materiais protegidos" como podemos ver a seguir.

\footnotetext{
${ }^{63}$ LITTO, F. Propriedade intelectual, Novas Tecnologias de Comunicação e Educação. Palestra dada no Congresso da ABED - Associação Brasileira de Ensino a Distância. Brasília: 1998. Available from Internet < URL:http://www.abed.org.br> [14.01.2002]
} 
A base legal da propriedade intelectual concede proteção, por tempo limitado, dos direitos exclusivos dos criadores às suas obras. Proteção que se dá em relação à expressão e estrutura das idéias.

Os materiais protegidos, que podem ser usados sem permissão, são chamados obras em domínio público e são assim identificadas:

* Têm mais de 150 anos que foram publicadas.

* Têm direitos reservados expirados.

* São traduzidas por órgão público.

* Apresentam informação fatual ou apenas uma idéia.

* Seu uso está enquadrado no conceito de "fair use" (uso honrado) (justificativa para uso, em certas condições, de material protegido sem permissão do autor, como por exemplo, para finalidade de crítica, comentário, reportagem noticiosa, ensino, trabalho erudito ou de pesquisa).

Com isso, tirando obras nestas circunstâncias, qualquer outra obra para ser publicada precisa de breve autorização. A equipe da Bibvirt tem feito um grande esforço para ampliar o acervo. Diversos contatos têm sido feitos com autores e editoras na tentativa de que elas disponibilizem pelo menos parte das obras publicadas. Infelizmente, ainda são muitos editores e autores que não entendem a importância da proposta da Bibvirt. Seria interessante que essa pesquisa fosse divulgada na tentativa de sensibiliza-los para essa nova realidade. 


\subsection{Funções de Aprendizagem Relacionadas à Bibvirt}

A sociedade da informação desenvolve-se através da operação de conteúdos sobre a infra-estrutura de conectividade. Portanto, seu desenvolvimento requer um esforço nacional para promover a disseminação da Internet, aumentar o volume de conteúdos que atendam às necessidades de informação e expressão dos cidadãos de todas as regiões do país e, ao mesmo tempo, prepará-los para usufruírem desses recursos.

A Bibvirt cumpre papel estratégico, para pessoas e comunidades diretamente conectadas à Internet, oferecendo acesso público gratuito aos seus conteúdos, oportunizando apoio em processos de ensino-aprendizagem a partir do momento que os professores se conscientizarem da necessidade de utilizar essa fonte de informação em suas práticas pedagógicas diárias. 
Para isso é importante que os professores de diferentes áreas de nível fundamental e médio sejam capacitados na utilização dos recursos tecnológicos. Na tabulação dos dados da pesquisa colocada no site da Bibvirt, percebi que $53 \%$ dos estudantes freqüentam escolas públicas e que suas escolas possuem computadores ligados à Internet. Dos estudantes de escolas particulares que responderam a pesquisa, $77 \%$ têm em sua escola computadores ligados à Internet. Ver gráficos 3.2.1 e 3.2.2

\section{Escolas Públicas com Computadores Ligados à Internet para os Alunos}

$47,0 \%$

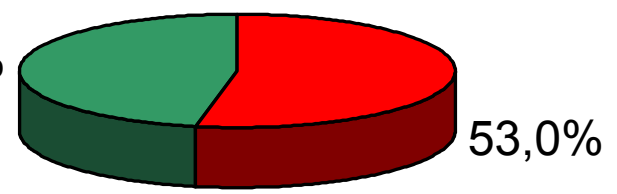

$\square$ escolas públicas ligadas à Internet

$\square$ escolas públicas NÃO ligadas à Internet

Gráfico 3.2.1

\section{Escolas Particulares com Computadores Ligados à Internet para os Alunos}

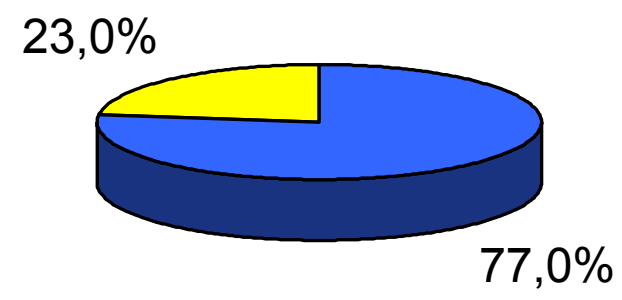

$\square$ escolas particulares ligadas à Internet

$\square$ escolas particulares NÃO ligadas à Internet

Gráfico 3.2.2 
No entanto, a maioria dos estudantes das escolas públicas $(50 \%)$ respondeu que somente alguns dos seus professores incentivam o uso da Internet para pesquisa, o que não é diferente para estudantes de escolas particulares onde $44 \%$ fizeram a mesma afirmação, tanto que $72,1 \%$ dos estudantes acessam a Internet de casa, como já apresentado anteriormente.

Ver gráficos: 3.2 .3 e 3.2.4.

\section{Incentivo dos Professores no Uso da Internet para} Pesquisa - Escolas Públicas

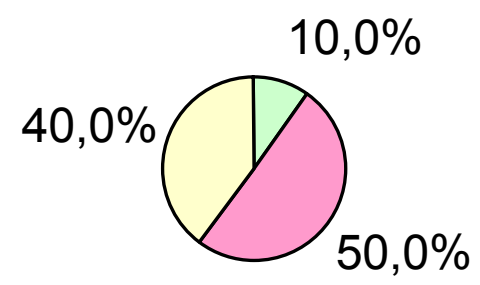

$\square$ sim, todos $\square$ alguns $\square$ nenhum

Gráfico 3.2.3

Incentivo dos Professores no Uso da Internet para Pesquisa - Escolas Particulares

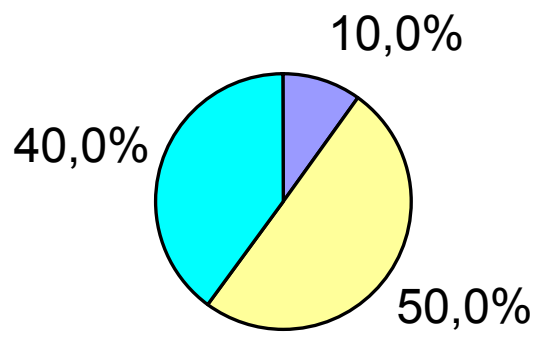

$\square$ sim, todos $\square$ alguns $\square$ nenhum

Gráfico 3.2.4 
A falta de orientação do professor de como utilizar a Internet para pesquisa reflete nas respostas apresentadas pelos alunos. Quando esses estudantes foram questionados sobre como é feita a orientação pelo professor, muitos alegaram que o professor somente pede a pesquisa na Internet, mas não dá nenhuma referência $(57,3 \%)$. Outros falaram que o professor pede a pesquisa indicando alguns sites interessantes, mas não acompanha o trabalho de investigação $(25,4 \%)$ e somente $(17,3 \%)$ afirmaram que os professores vivenciam o processo de busca de informação com seus alunos, fornecendo o endereço de alguns sites interessantes e estimulando a procura de outros relacionados ao tema.

O objetivo da Bibvirt não é oferecer orientação ao professor no processo de busca de informação. Ela deve somente prover alunos, professores e demais usuários com material de qualidade de fácil acesso e recuperação, livre de qualquer viés pedagógico. Mas, a Escola do Futuro da USP, por considerar essa questão relevante, fez parceria com os promotores do "Webquest" (www.webquest.futuro.usp.br), trazendo para o cenário nacional essa nova metodologia que tem por finalidade orientar o processo de busca de informações na Internet, no âmbito educacional, estimulando a pesquisa e o pensamento crítico. A combinação desta metodologia com a possibilidade de busca de informações de qualidade na Bibvirt podem criar ricas oportunidades de aprendizado, engajando alunos e professores em processos educacionais onde oportunize o prazer pela pesquisa, o pensamento crítico, o protagonismo juvenil e a produção de material com qualidade num processo efetivo de aprendizagem. 
Apesar da Bibvirt em si não oferecer uma metodologia de pesquisa, seus usuários tiveram oportunidade, na pesquisa colocada no site, de relatar as situações de aprendizagem que vivenciaram a partir das informações que obtiveram no acervo da Bibvirt, como podemos ver abaixo:

\begin{tabular}{|c|c|}
\hline FUNÇÃO DE APRENDIZAGEM & USUÁRIO \\
\hline Apresentação de um seminário sobre métodos anticoncepcionais. & $\begin{array}{l}\text { Estudante de } \\
\text { Ensino } \\
\text { Fundamental II }\end{array}$ \\
\hline $\begin{array}{l}\text { A Bibvirt propiciou a leitura de livros literários "Pelo fato do meu pai } \\
\text { querer leitura constante, li diversos livros da Bibvirt. Para surpresa dele, } \\
\text { sempre que ele comentou sobre algum livro, eu já havia lido". }\end{array}$ & $\begin{array}{l}\text { Estudante de } \\
\text { Ensino } \\
\text { Fundamental II }\end{array}$ \\
\hline Utilização do acervo para se preparar para o vestibular. & $\begin{array}{l}\text { Estudante de } \\
\text { Ensino Médio }\end{array}$ \\
\hline $\begin{array}{l}\text { Utilização para desenvolvimento de pesquisa sobre elementos de } \\
\text { máquinas e cálculo mecânico. }\end{array}$ & $\begin{array}{l}\text { Estudante de } \\
\text { Ensino Médio }\end{array}$ \\
\hline $\begin{array}{l}\text { Apresentação de um trabalho sobre o rádio e a Era Vargas com } \\
\text { recursos de sons e imagens tirados deste e de outros sites. }\end{array}$ & $\begin{array}{l}\text { Estudante de } \\
\text { Ensino Médio }\end{array}$ \\
\hline $\begin{array}{l}\text { "Peguei alguns materiais didáticos para meu professor, pois ele } \\
\text { necessitava preparar uma aula mais educativa". }\end{array}$ & $\begin{array}{l}\text { Estudante de } \\
\text { Ensino Médio }\end{array}$ \\
\hline $\begin{array}{l}\text { "Utilização do material didático da Bibvirt como uma fonte a mais, além } \\
\text { dos livros escolares". }\end{array}$ & $\begin{array}{l}\text { Estudante de } \\
\text { Ensino Médio }\end{array}$ \\
\hline $\begin{array}{l}\text { Utilização para dar uma aula de Biologia, sobre o sangue, para os } \\
\text { colegas. }\end{array}$ & $\begin{array}{l}\text { Estudante de } \\
\text { Ensino Médio }\end{array}$ \\
\hline $\begin{array}{l}\text { Uso da Bibvirt para ler clássicos da Literatura Brasileira a fim de se } \\
\text { inteirar do painel literário de nosso país. }\end{array}$ & $\begin{array}{l}\text { Estudante } \\
\text { Universitário }\end{array}$ \\
\hline $\begin{array}{l}\text { Conhecer um pouco de alguns livros não lidos, sem a necessidade de } \\
\text { dispor de muito tempo. }\end{array}$ & $\begin{array}{l}\text { Estudante } \\
\text { Universitário }\end{array}$ \\
\hline $\begin{array}{l}\text { Utilização do texto "Os sertões", e alguns comentários sobre Euclides da } \\
\text { Cunha, para ilustrar um seminário. }\end{array}$ & $\begin{array}{l}\text { Estudante de } \\
\text { Filosofia }\end{array}$ \\
\hline $\begin{array}{l}\text { Utilização da Bibvirt através da escolha de trechos de textos para } \\
\text { serem lidos em sala de aula, ou para realizar alguma tarefa de } \\
\text { interpretação de texto. Também usou para leitura de algumas obras, que } \\
\text { não havia lido. Divulgou aos alunos, mencionando o importante } \\
\text { conteúdo deste site. }\end{array}$ & $\begin{array}{l}\text { Professor de } \\
\text { Ensino Médio }\end{array}$ \\
\hline
\end{tabular}




\begin{tabular}{|l|l|}
\hline $\begin{array}{l}\text { Utilização da seção de provas dos vestibulares para desenvolver } \\
\text { trabalhos com os alunos. }\end{array}$ & $\begin{array}{l}\text { Professor de } \\
\text { Ensino Médio }\end{array}$ \\
\hline $\begin{array}{l}\text { Utilização do material didático como suporte para as aulas de laboratório } \\
\text { de Física. }\end{array}$ & $\begin{array}{l}\text { Professor de } \\
\text { Ensino Médio }\end{array}$ \\
\hline $\begin{array}{l}\text { Usou o site para ouvir sons de aves brasileiras com alunos de quarta } \\
\text { série. "Os alunos ficaram fascinados, pois puderam ouvir sons de aves } \\
\text { que provavelmente nunca verão pessoalmente. Também gostaram das } \\
\text { ilustrações de algumas aves feitas por desenhistas especializados". } \\
\text { Discussão sobre a importância do trabalho deste profissional no registro } \\
\text { científico de certas espécies no meio ambiente (animais, vegetais...). Foi } \\
\text { uma aula muito gostosa e muitos alunos anotaram o site para poder } \\
\text { ouvir em casa e mostrar aos pais". }\end{array}$ & Pedagogo \\
\hline $\begin{array}{l}\text { Impressão de diversos textos para discussão em reuniões pedagógicas } \\
\text { e com os alunos. }\end{array}$ & $\begin{array}{l}\text { Coordenador } \\
\text { Pedagógico }\end{array}$ \\
\hline $\begin{array}{l}\text { Apresentação de um seminário sobre Segurança do Trabalho, na } \\
\text { Faculdade e para o curso de Desenho Arquitetônico, além da utilização } \\
\text { do material didático de Desenho Técnico. }\end{array}$ & $\begin{array}{l}\text { Administradora } \\
\text { de Empresas - } \\
\text { "Estudante } \\
\text { Utilização para pesquisas escolares da filha. Além de ter usado os } \\
\text { eterna”. }\end{array}$ \\
\hline tilização do material do Telecurso 2000 para dar aulas de Português. \\
mora nos EUA \\
\hline
\end{tabular}

Apesar dos relatos serem interessantes para conhecermos o que o usuário fez com a informação que ele encontrou na Bibvirt, simplesmente esses relatos não possibilitam a verificação de situações reais de aprendizagem, pois eles não explicitam a forma como o conteúdo foi trabalhado e nem o que as informações encontradas significaram para ele ou para seus alunos.

Seria interessante, em uma próxima pesquisa, pedir que os usuários detalhem a forma como trabalharam com a informação e avaliem o quão significante foi para seu aprendizado ou de seus alunos. 


\subsection{Análise do Processo de Busca de Informação}

A Internet ainda apresenta dificuldades que demandam maior grau de intimidade com redes eletrônicas: a informação é dispersa e heterogênea. Outro fator de dificuldade para o usuário inexperiente é o desenho das telas de apresentação e a estrutura das páginas, muitas vezes pressupondo uma certa familiaridade com ambientes computacionais mais sofisticados.

A tendência de muitos desenvolvedores de sites é criar interfaces e sistemas de busca de informação, não observando o processo do usuário, querendo que ele se adapte ao sistema.

$\mathrm{Na}$ tentativa de desenvolver sistemas eficientes, devemos levar em consideração a colocação feita por Taylor $(1984)^{64}$ defensor da idéia de que devemos enfocar, prioritariamente, nos estudos alternativos, o problema individual dos usuários. Que informação um indivíduo quer encontrar no sistema de informação, que uso fará dela, e como o sistema pode melhor ser projetado para preencher essas necessidades de informação, dependerão exclusivamente dele próprio, de seu propósito na busca de informação e do uso da mesma na transposição das lacunas.

Com isso, na tentativa de conhecer como é o processo de busca de informação dos usuários da Bibvirt, algumas questões foram apresentadas a eles onde puderam descrever as dificuldades encontradas e como o sistema pode melhor ser projetado para facilitar sua navegação. Os resultados foram:

\footnotetext{
${ }^{64}$ TAYLOR, R. The Value-added Processes in Document-Based Systems: Abstracting and Indexing Services. In: Information Services and Use. V.4. № 3. Pg. 127-46. 1984 June.
} 
A maioria dos usuários (68,5\%) respondeu que encontra com facilidade as informações contidas no acervo da Bibvirt e 57\% afirmaram que a informação encontrada continha exatamente os dados que estavam procurando. (Ver gráfico 3.3.1 e 3.3.2).

Facilidade para Localização do Acervo

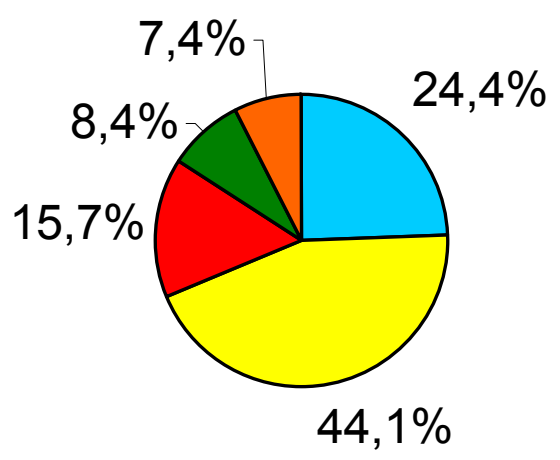

$\square$ sempre $\square$ quase sempre $\square$ às vezes $\square$ raramente $\square$ nunca

Gráfico 3.3.1

\section{Relação Dados X Necessidade}

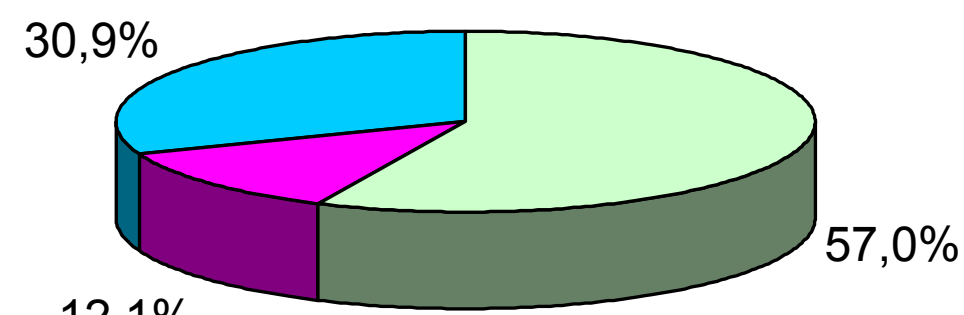

$12,1 \%$

$\square$ continha exatamente os dados solicitados

$\square$ continha dados muito sofisticados

$\square$ continha dados muito simples

Gráfico 3.3.2 
Se levarmos em consideração esses resultados, podemos dizer que a Bibvirt possui um sistema de busca de informação eficiente, mas na tentativa de torná-lo ainda melhor, perguntamos aos usuários como o sistema poderia melhor ser projetado para atender às suas necessidades.

Como sugerido por Dervin (1983) ${ }^{65}$, na abordagem Sense-Making, devemos levar em consideração a individualidade (usuários devem ser tratados como indivíduos e não como conjunto de atributos demográficos) para definir padrões (analisando as características individuais de cada usuário, chega-se aos processos cognitivos comuns a maioria). Dessa forma obtivemos as seguintes sugestões:

* Melhorar o layout da página inicial.

* Possibilitar que todos os tópicos fiquem na primeira página por meio de um frame lateral.

* Inserir um botão de busca para o site todo.

* Substituir o sistema de busca por um mais moderno.

* Atribuir diferentes palavras-chave para um mesmo assunto, tipo chave composta ou chave secundária.

* Possibilitar a busca de diferentes formas: por assunto, temas, matérias, títulos de livros, por curso e ordem alfabética.

* Ter um professor que oriente a busca de informações.

* Melhorar o sistema de gravação de pesquisa para que não tenha que começar o processo novamente num próximo momento.

* Diminuir o número de links para acessar uma informação. O grande número de links aumenta o tempo de acesso e conseqüentemente o gasto telefônico.

* Verificar os links. Alguns estão quebrados e não levam a lugar nenhum.

* Apresentar o resultado da busca em uma nova janela.

${ }^{65}$ DERVIN, B. An overview of Sense-Making research: concepts, methods and results to date. (on line) In: International Communications Association's Annual Meeting. Dallas, May, 1983. Available from www, <URL: http:// www.eca.usp.br/prof/sueli/sm1983 4.html> 
Nesta pesquisa, os usuários também tiveram oportunidade de relatar sobre que informações gostariam de encontrar no site, nos ajudando a identificar por onde devemos ampliar o acervo. As necessidades apresentadas foram:

* Resenhas de obras literárias

* Literatura Infantil

* Obras de Paulo Coelho

* Primeiros filósofos

* Manuais e apostilas de informática

* Informações sobre novidades técnicas e científicas

* Materiais na área de medicina e informática

* Informações sobre economia e didática

* Conceitos ou definições de automação de bibliotecas

* Glossário de termos técnicos

* Dicionário de outras línguas com a pronúncia das palavras

* Atlas

* Elementos constituintes da Terra

* Características dos elementos químicos

Podemos perceber que muitas das informações solicitadas pelo usuário fogem ao foco da Bibvirt, o que me leva a duas hipóteses:

* Ou os internautas não observam qual é o foco do acervo da Bibvirt, pois não têm o costume de ler e interpretar as informações que estão sendo apresentadas, o que é bem provável já que por uma pesquisa do Instituto Paulo Montenegro ${ }^{66}$ (2001), 31\% da população alfabetizada no Brasil foi classificada no nível 1 de alfabetismo (consegue tirar uma informação explícita apenas em textos muito curtos); 34\% no nível 2 ( consegue também localizar uma informação não explícita em textos de maior extensão); e 26\% no nível 3 de alfabetismo (é capaz de ler textos mais longos, localizar mais de uma informação e estabelecer relações entre diversos elementos do texto).

\footnotetext{
${ }^{66}$ INSTITUTO PAULO MONTENEGRO. Analfabestismo. Available from Internet <URL:http://www.ipm.org.br/analf indicador.htm> [14.01.2002]
} 
- Ou a oferta de material em Língua Portuguesa na Internet é baixo, o que também é uma hipótese bem provável, pois pela pesquisa sob a supervisão de Pimienta ${ }^{67}$ (2001), a presença absoluta de conteúdo em Língua Portuguesa na Internet é de somente $5,4 \%$ do conteúdo total da rede contra $52 \%$ representado pela Língua Inglesa. Mas, não é tão pouco se levarmos em consideração que o número de internautas que falam a Língua Portuguesa é de 11,5 milhões de pessoas $(2,5 \%)$, bem menor do que o número de internautas que falam a Língua Inglesa que são um total de 215,6 milhões de internautas $(47,6 \%)$.

Se formos analisar proporcionalmente o número de sites em Língua Portuguesa em relação ao número de falantes desta mesma língua na Internet, iremos perceber que essa relação é quase o dobro da proporção representada pela Língua Inglesa. Mesmo assim, é interessante que cada vez mais as informações sejam disponibilizadas em Língua Portuguesa, pois é somente desta forma que teremos maiores possibilidades de participar do mundo globalizado.

${ }^{67}$ PIMIENTA, D. org. Lugar das Línguas Latinas na Internet. Funredes, União Latina: 2001. Available from Internet < http://www.unilat.org/public/L5-PT.doc > [14.01.2002] 
Diante da pesquisa e comentários feitos pelos usuários da Bibvirt, a equipe da Bibvirt (ver Anexo 5) desenhou um novo layout para o site (ver figura 3.3.1) com a finalidade de melhorar a navegação e o processo de busca e recuperação de informações para os usuários.

O novo layout possui um frame lateral e um superior que ficam presentes durante toda a navegação. No frame central da página principal temos notícias que são atualizadas constantemente. Quando alguma informação é acessada no acervo, também é neste frame que ela é apresentada.

O frame superior está organizado de acordo com as diferentes mídias encontradas no acervo. Para cada mídia, no frame lateral aparecem possibilidades de busca por ordem alfabética ou por tema, que levam a um conjunto de sub-tópicos relacionados.

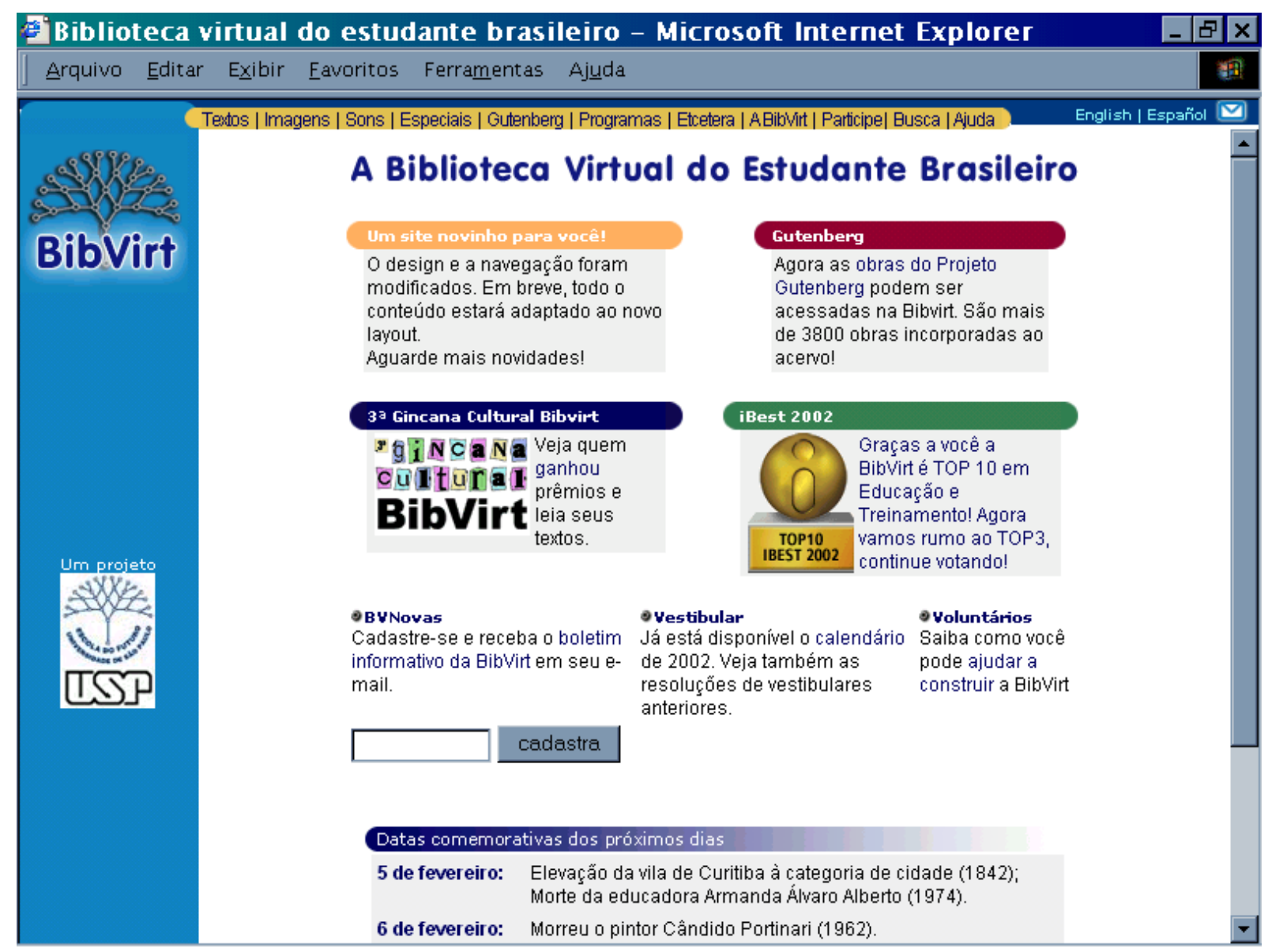

Figura 3.3.1 - Novo layout do site da Bibvirt 
Como um dos principais focos da Bibvirt é a Literatura, atenção especial foi dada a esse item. Quando os usuários acessam o link "textos" no frame ${ }^{68}$ superior, têm à disposição no frame lateral uma sub-divisão que leva somente aos textos que compõem o acervo literário e uma outra que leva aos demais textos.

Ainda no link Literatura, os usuários têm a possibilidade de pesquisar as obras por autor, por título ou por gênero, como apresentado na figura 3.3.2 abaixo. No item "temáticos", os textos estão estruturados de acordo com as três grandes áreas que estruturam o ensino: biológicas, exatas e humanas.

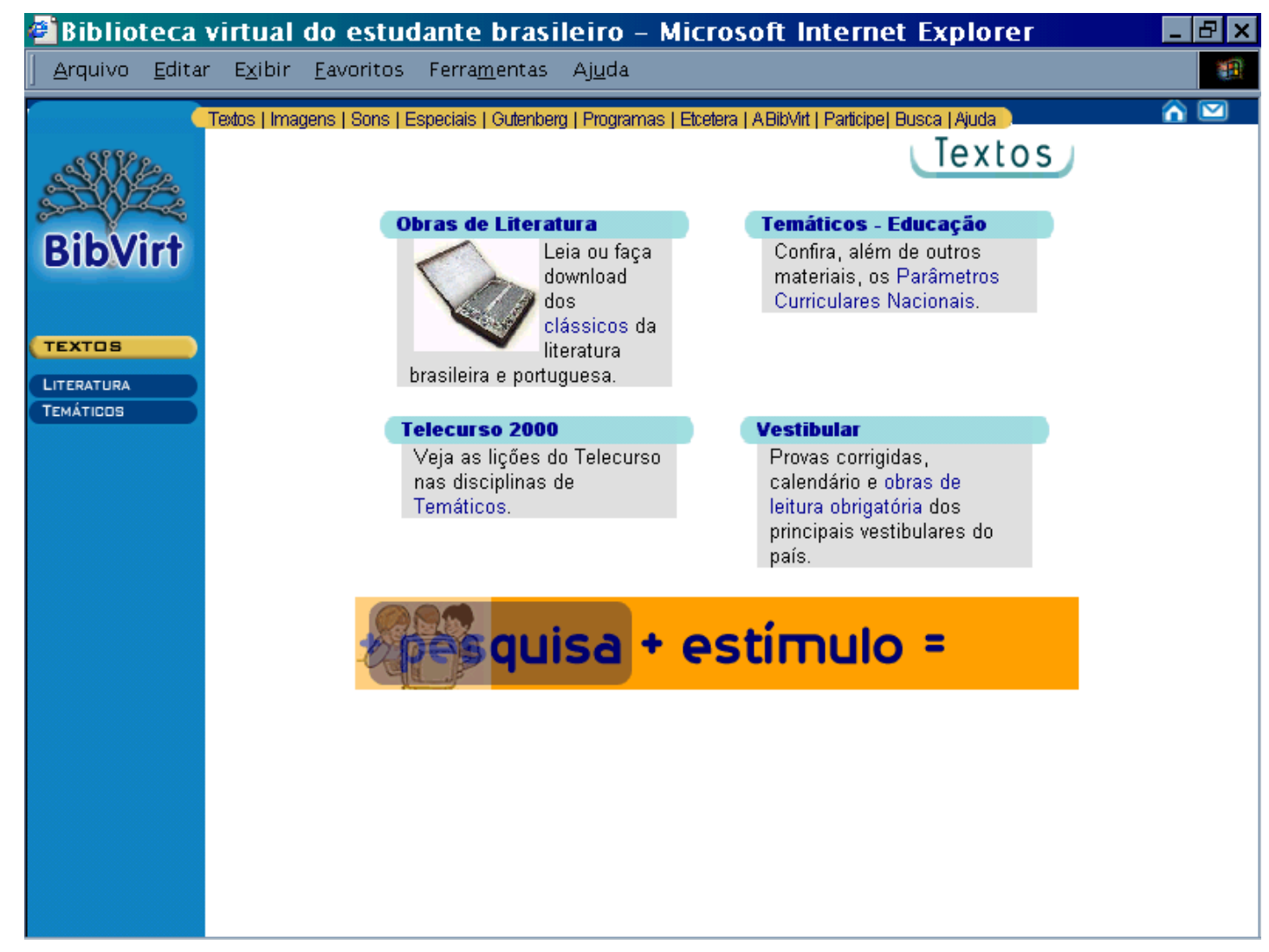

Figura 3.3.2 - Apresentação da estrutura do link "Textos"

Seria mais interessante que os textos estivessem organizados de acordo com as três áreas definidas pelos Parâmetros Curriculares Nacionais: Linguagens, Códigos e suas Tecnologias, Ciências da Natureza, Matemática e suas Tecnologias e

\footnotetext{
${ }^{68}$ FRAME - [Ing.] (Moldura). Recurso da linguagem HTML, definido pelos comando <frame $><$ /frame>, que permite dividir uma página em quadros cada qual podendo conter documentos distintos e independentes (links, imagens, textos, botões, etc.). Os frames só podem ser quadrados ou retangulares e sua disposição varia de acordo com a criatividade do criador. Totalmente ajustáveis permitem dividir uma páginaem quantas partes se fizer necessário.
} 
Ciências Humanas e suas Tecnologias. Essa divisão tem como base a reunião de conhecimentos que compartilham o mesmo objeto de estudo e, portanto, mais facilmente se comunicam, criando condições para que a prática escolar se desenvolva numa perspectiva de interdisciplinaridade.

Como apresentado nos $\mathrm{PCN}^{6} \mathrm{~s}^{69}$, "A estruturação por área do conhecimento justificase por assegurar uma educação de base científica e tecnológica, na qual conceito, aplicação e solução de problemas concretos são combinados com uma revisão dos componentes sócio-culturais orientados por uma visão epistemológica que concilie humanismo numa sociedade tecnológica."

Como o projeto Gutemberg oferece, em seu acervo, materiais em diferentes mídias, um link especial foi reservado à ele. Ver figura 3.3.3

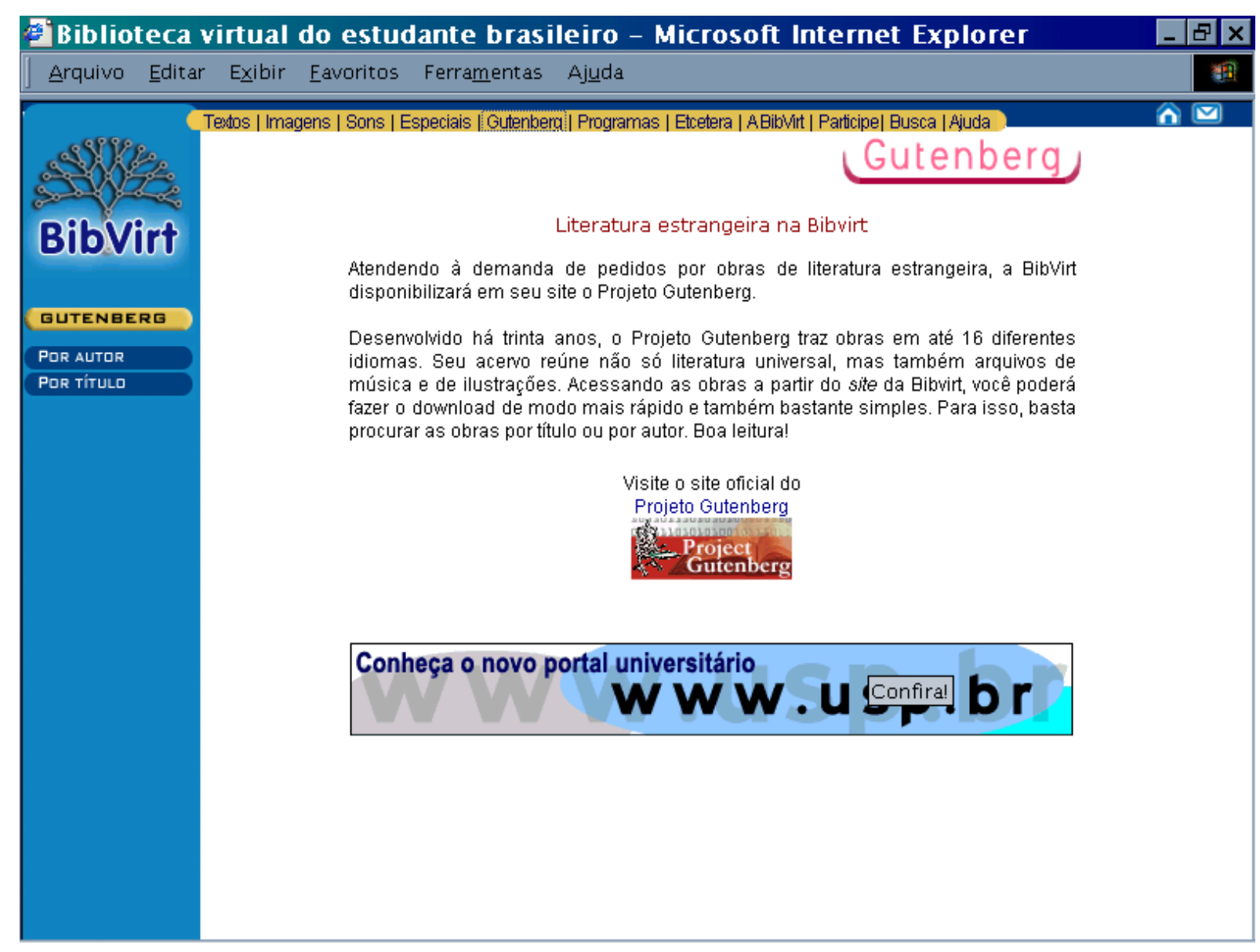

Figura 3.3.3 - Projeto Gutemberg

${ }^{69}$ PARÂMETROS CURRICULARES NACIONAIS - ENSINO MÉDIO. A reforma curricular e a organização do Ensino Médio. Ministério da Educação. Secretaria de Educação Média e Tecnológica. Brasilia: Ministério da Educação, 1999. 364 p. 
Uma outra novidade no novo layout do site é que todo o material do Telecurso 2000 será revisado com o intuito de identificar um título mais significativo para cada um dos tópicos presentes em seu acervo. A busca de informações acontecerá não só pelo formato de arquivo TXT, mas também por $\mathrm{PDF}^{70}$ possibilitando que a busca aconteça também no material do Telecurso, que está todo em PDF. (ver figura 3.3.4)

Por enquanto o sistema disponível para busca, no site, é um software gratuito que pode ser encontrado no endereço: http://www.htdig.org/ . Para mudar esse sistema para um mais sofisticado é necessário encontrar um patrocinador. A idéia é, em um futuro próximo, utilizar um tessaurus da área educacional que permita uma classificação e indexação mais eficiente.

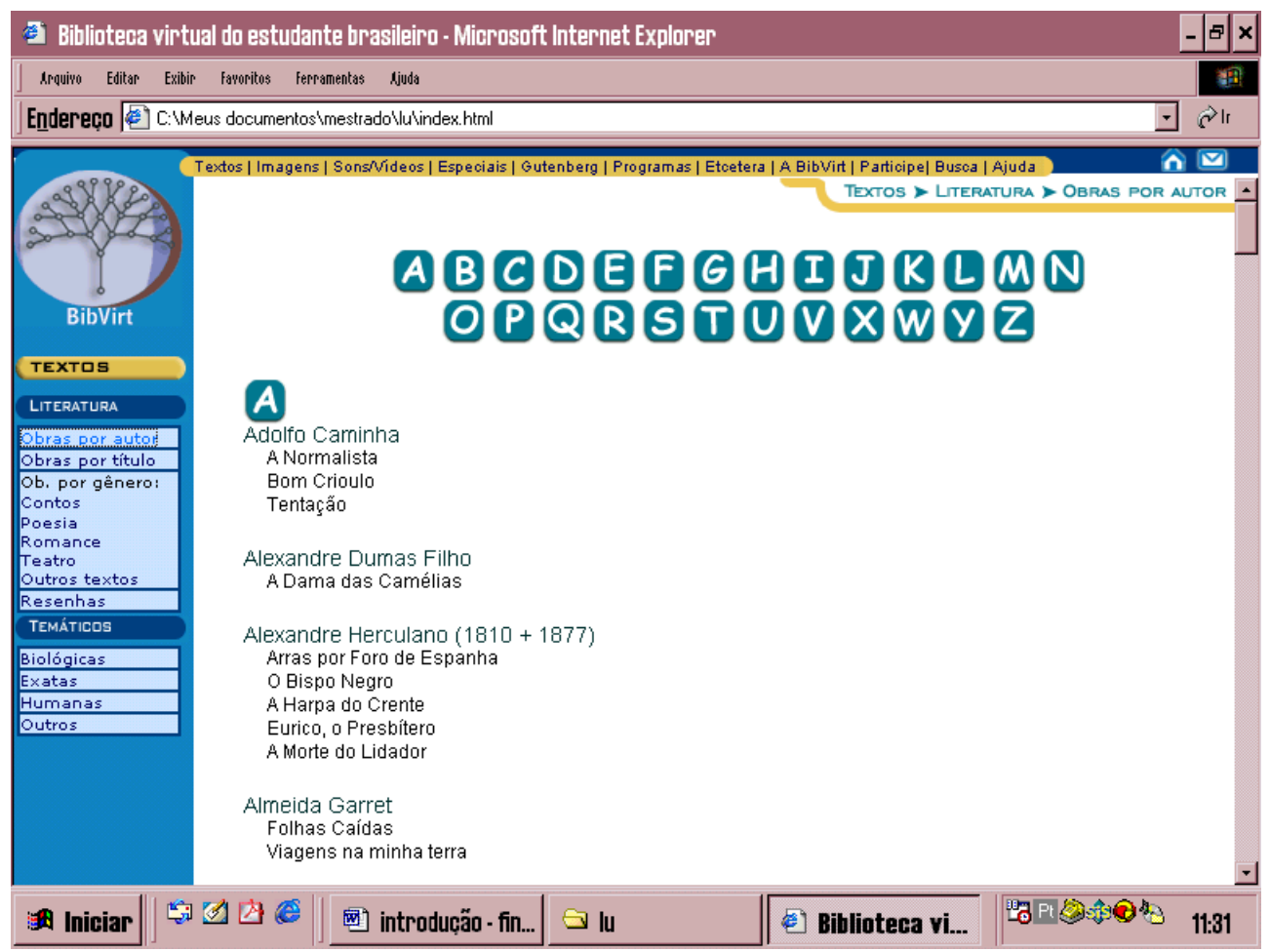

Figura 3.3.4 - Apresentação das possibilidades de pesquisa nos textos

O novo layout do site foi publicado em novembro de 2001. Seria interessante que outra pesquisa fosse feita para comparar e avaliar o novo processo de busca de informações, na tentativa de saber se a nova forma de organização satisfaz os usuários.

\footnotetext{
${ }^{70}$ OLIVEIRA, R. S. Minidicionário Compacto de Informática. São Paulo: Editora Rideel. 1999. PDF - forma abreviada Portable Document Format - formato portável de documento.

Formato de armazenamento de dados - principalmente relativos a imagens gráficas - que facilita a operação de transferência de um sistema para outro, mesmo com arquitetura diferente, mantendo o aspecto visual praticamente inalterado.
} 


\subsection{Recuperação da Informação}

Revisões sobre as percepções que cientistas da informação possuem dos atuais usuários tornam-se, cada vez mais, questão fundamental na real adequação dos sistemas de informação. Visualizar holisticamente estes usuários como seres humanos, com necessidades específicas e individuais não é tarefa fácil, porém imprescindível quando se procura a qualidade ideal.

A discussão proposta por Dervin (1983) ${ }^{71}$ sobre a necessidade de tornar o sistema de informação flexível, aceitando as diferenças, e construir assim um sistema mais responsável e democrático, coloca o usuário definitivamente como agente que através de suas necessidades pessoais deve definir o sistema, fazendo dele algo realmente útil. Com isso, analisar o processo de recuperação de informações, aqui subentendido como a forma que o usuário tem acesso ao material disponível no site, é criar oportunidades de democratização do acervo.

Nessa perspectiva, analisou-se seu processo de recuperação de informações e chegou-se a conclusão que apesar da maioria das informações contidas no acervo da Bibvirt estar disponível em $\mathrm{PDF}^{72}$, não há empecilho para a maioria dos usuários no acesso. Na pesquisa $90,6 \%$ dos usuários afirmaram não ter dificuldade para acessar as informações contidas no acervo. Ver gráfico 3.4.1.

${ }^{71}$ DERVIN, B. An overview of Sense-Making research: concepts, methods and results to date. (On line) In: International Communications Association's Annual Meeting. Dallas, May, 1983. Available from Internet: <URL: http:// www.eca.usp.br/prof/sueli/sm1983 4.html>. [01 Dec 2001] 


\section{Facilidade para Leitura do Material}

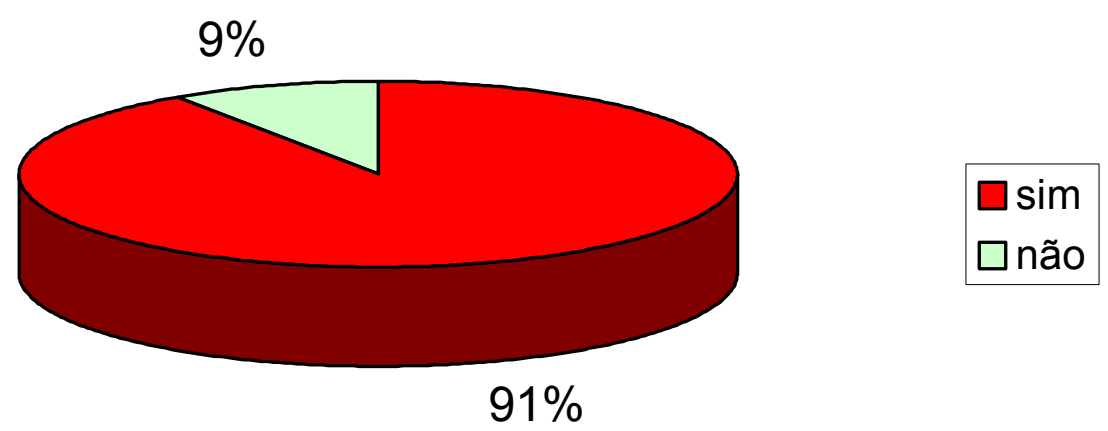

Gráfico 3.4.1

Mesmo assim, os usuários fizeram algumas sugestões, tais como:

* Oferecer o material em PDF e HTML ${ }^{73}$.

* Disponibilizar as provas dos vestibulares também juntas em uma versão compactada.

* Oferecer outras formas de recuperação de informação além do download.

${ }^{73}$ OLIVEIRA, R. S. Minidicionário Compacto de Informática. São Paulo: Editora Rideel. 1999.

HTML - Forma abreviada de HyperText Markup Language - Linguagem de sinalização de hipertexto. Linguagem de programação específica para criação de hipertexto, permitindo facilmente criar hyperlinks num texto comum. A HTML é usada na WWW. 
Outro item abordado na pesquisa foi a forma como o usuário faz a leitura dos livros encontrados no acervo da Bibvirt. Pelo que se pode observar, os usuários fazem a leitura de formas bem diversificadas devendo, com isso, continuar sendo oferecida à recuperação das informações de diferentes formas. Ver gráfico 3.4.2.

\section{Leitura do Material}

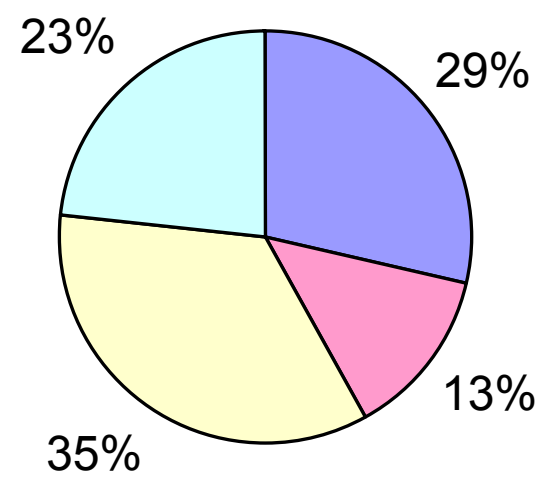

lâ na tela do micro

$\square$ imprimi direto da Internet

$\square$ faz download e depois lê natela do micro

$\square$ faz download e depois imprime

Gráfico 3.4.2 
$\mathrm{Na}$ dificuldade de recuperar informações, muitas vezes os usuários requisitaram a ajuda da equipe da Bibvirt. Quando isso aconteceu, 69,6\% dos usuários responderam que conseguiram resolvê-la e $80 \%$ deles, disseram que a informação acrescentou algo de novo nos seus conhecimentos de informática. (Ver gráficos 3.4 .3 e 3.4.4)

\section{Resolução das Dúvidas com o Apoio da Equipe da Bibvirt}

$\square \operatorname{sim}$
$\square$ não

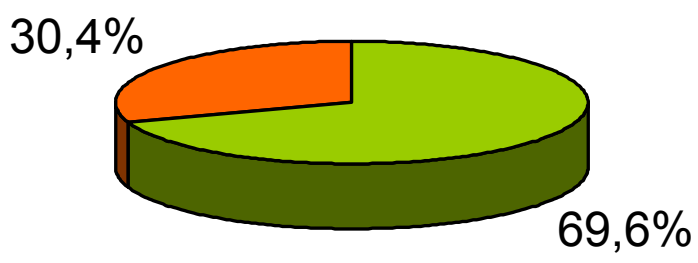

Gráfico 3.4.3

Contribuição da Ajuda para Melhoria dos Conhecimentos de Informática

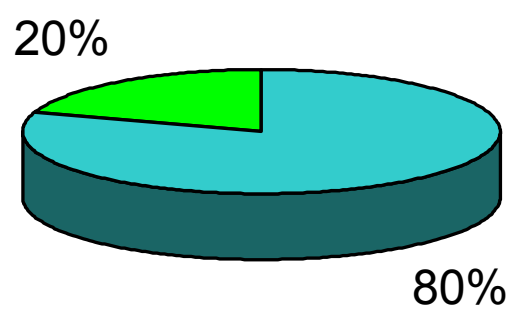

Gráfico 3.4.4 
Existe a idéia de contar com voluntários que fiquem on-line auxiliando o usuário não só no seu processo de busca informações, mas também orientando no processo de recuperação de informações, tarefa importante quando se quer que o usuário tenha sucesso em sua pesquisa no site.

Para finalizar este tópico, a partir das considerações feitas pelos usuários da Bibvirt, o novo site conta com a possibilidade de se ter o material nos formatos HTML, TXT ou em PDF, como também para download no formato zipado ${ }^{74}$.

As imagens estão no formato jpg, os sons em .ra, .ram, mp3 e mid e os vídeos em wav. Para qualquer um dos formatos disponíveis, encontramos, para download, na própria Bibvirt o software necessário para sua execução, facilitando a recuperação de informações pelo usuário. (Ver gráficos 3.4.5, 3.4.6 e 3.4.7)

Além dos softwares disponíveis para os diferentes formatos, encontramos softwares educacionais para aplicações específicas em algumas disciplinas, como é o caso dos mapas de Geografia.

\footnotetext{
${ }^{74}$ OLIVEIRA, R. S. Minidicionário Compacto de Informática. São Paulo: Editora Rideel. 1999. Zipado - gíria que quer dizer compactar dados utilizando o software pkzip.

Pkzip - um dos mais eficientes e difundidos programas utilitários compactadores de dados, criado pela empresa Pkware Inc. e distribuído em diversas versões shareware. (versão não completa do programa ou otimizada de forma gratuita).

O Pkzip é normalmente fornecido junto com um pacote de outros utilitários da Pkware, como o Pkunzip e o Zip2exe. Os arquivos gerados pelo Pkzip têm extensão de nome .zip.
} 


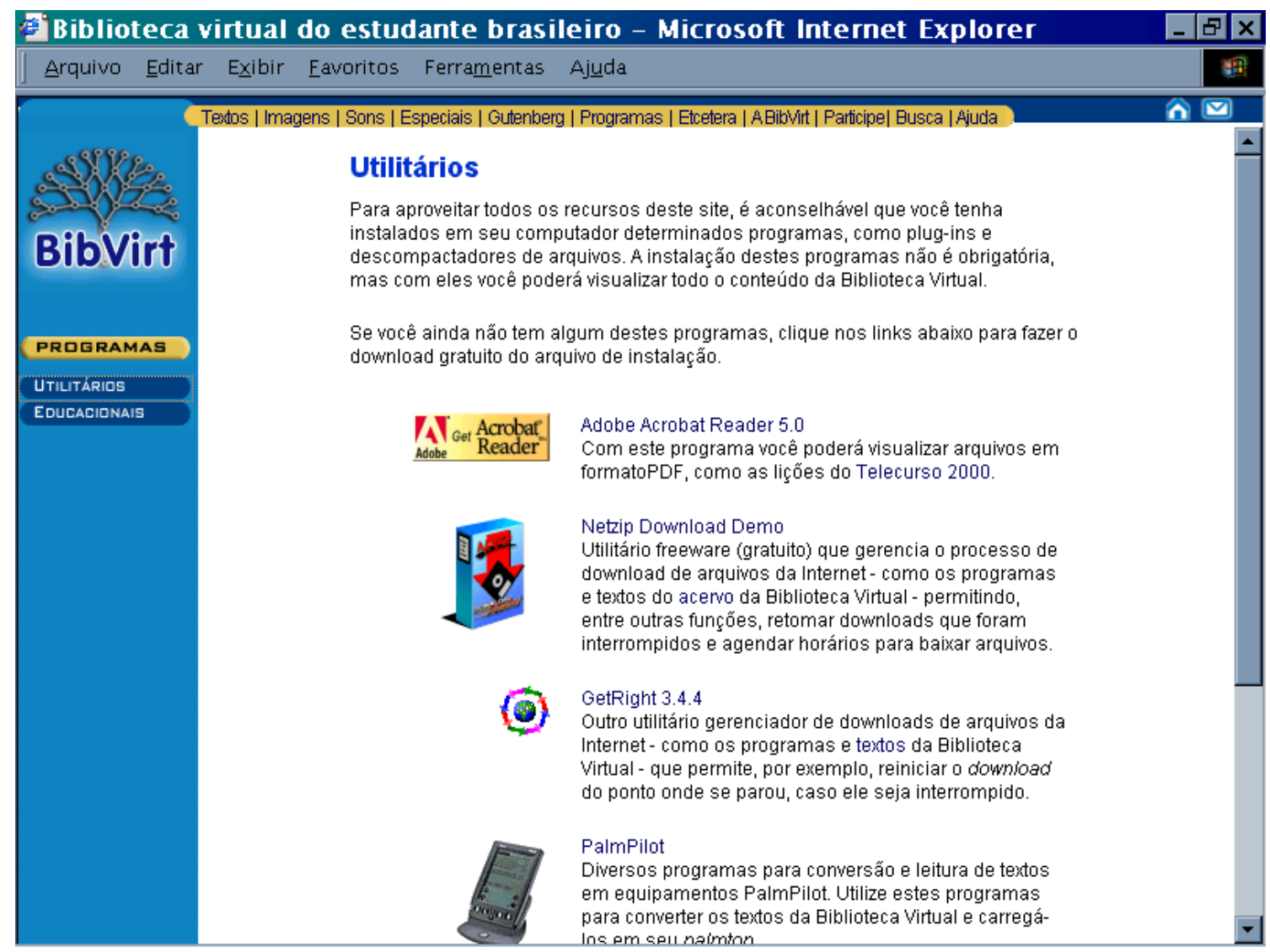

Figura 3.4.5 - Programas para download

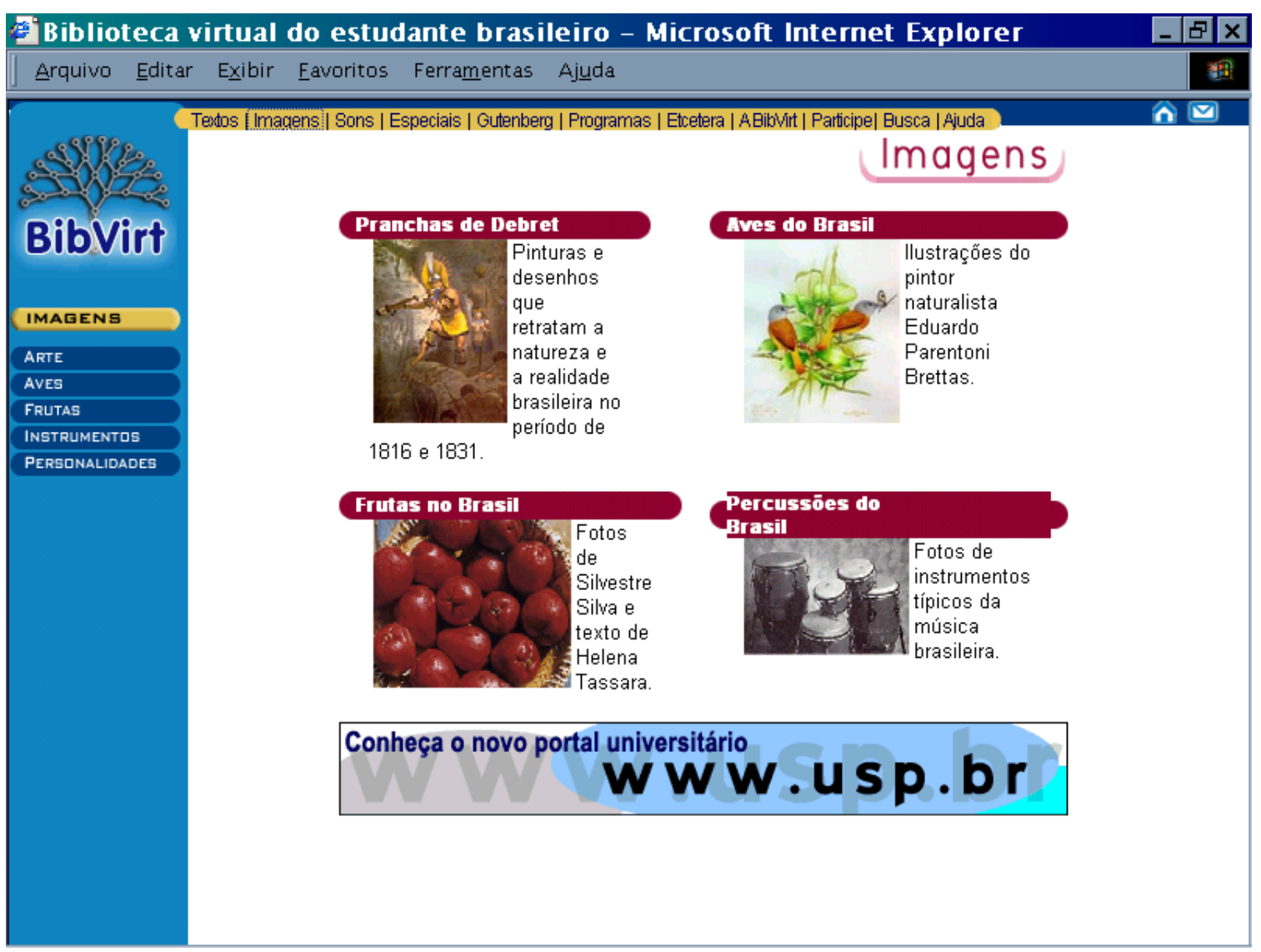

Figura 3.4.6 - Página do arquivo de imagens 


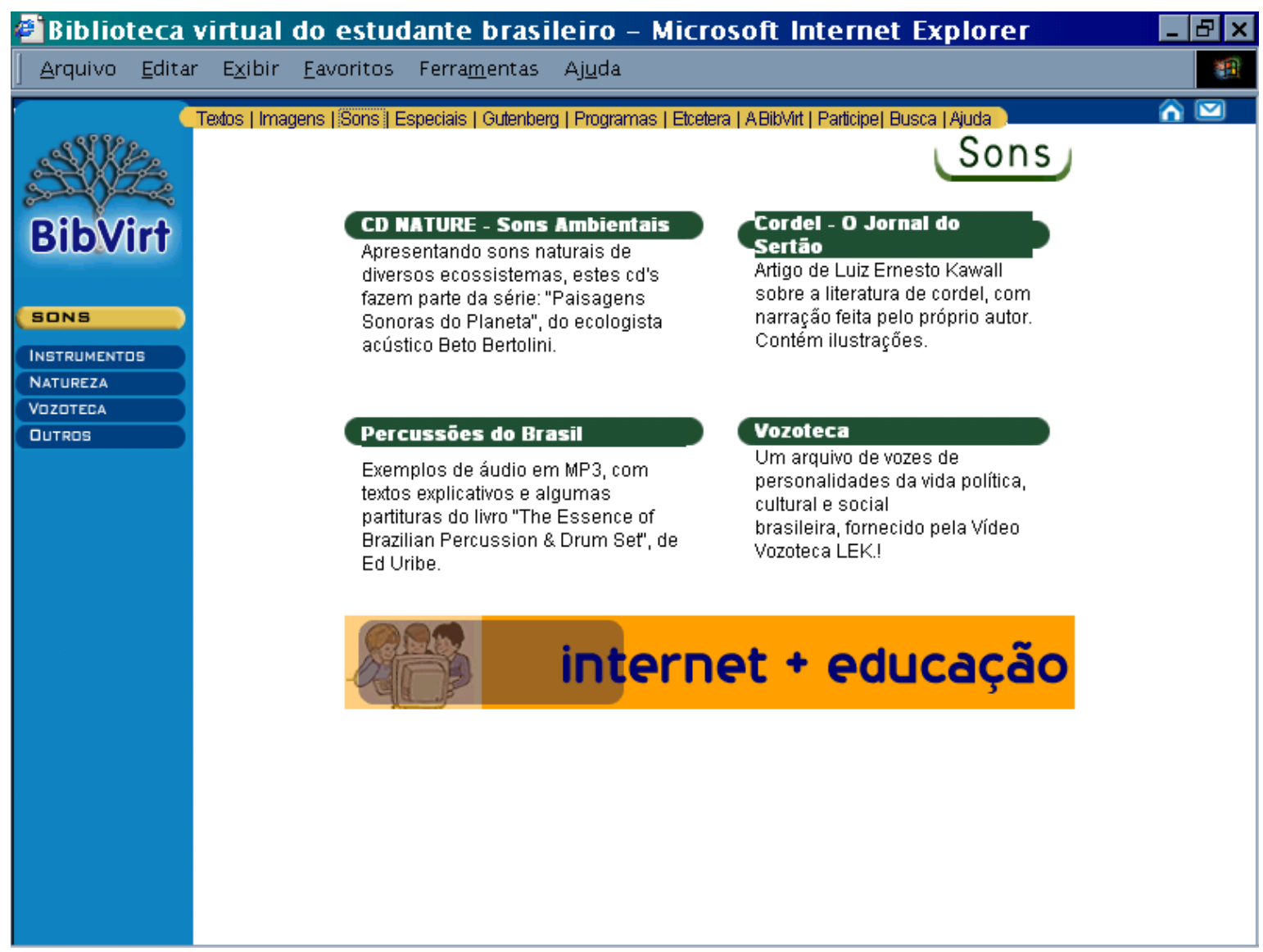

Figura 3.4.7 - Página dos arquivos de sons

Um ícone de impressão será colocado em cada página, evitando-se a impressão dos frames.

Hoje, quando acrescentamos uma das páginas da Bibvirt no bookmark ${ }^{75}$, temos como resultado o endereço da página de abertura. Com o objetivo de sanar esse problema, está sendo criado um endereço diferente para cada página que compõe o site da Bibvirt.

Com isso, encerra-se a análise dos dados coletados na pesquisa. O principal foi verificar que a Bibvirt está dentro da proposta apresentada em seu sumário executivo original onde seu mentor Litto (1997) demonstrou interesse em formar uma

${ }^{75}$ OLIVEIRA, R. S. Minidicionário Compacto de Informática. São Paulo: Editora Rideel. 1999.

Bookmark - marca-livro. Tal como se fosse uma marcação de página de um livro, um bookmark é um recurso disponível em alguns softwares, como os browsers para a Internet e alguns processadores de texto, visando facilitar o acesso a informações marcadas pelo usuário.

Assim, o usuário, ao acessar um conjunto grande de dados (textos, apresentações multimídia, páginas da Internet, etc), pode marcar aqueles que forem mais importantes para poder acessa-los rapidamente depois. 
equipe para desenvolver um site que ofereceria recursos educacionais úteis para estudantes e professores ajudando a suprir a carência de bibliotecas escolares no País e de materiais de qualidade em Língua Portuguesa na Internet.

As modificações que foram feitas no site da Bibvirt, embasadas no resultado da pesquisa desta dissertação de mestrado, têm como proposta tornar mais eficiente o processo de busca e recuperação de informações do usuário atendendo a demanda apresentada por ele.

Seria interessante que uma nova análise fosse feita ao final do próximo ano com a finalidade de comparar e avaliar quão significativas foram as mudanças ocorridas no site da Bibvirt decorrentes deste trabalho.

No próximo capítulo, será apresentada uma síntese do trabalho desenvolvido, avaliando os pontos fortes e fracos deste projeto de pesquisa, bem como uma análise da contribuição da Bibvirt para o cenário nacional. 


\section{CAPÍTULO 4}

\section{Considerações finais}

Onde está a vida,

Que perdemos ao viver?

Onde está a sabedoria,

Que perdemos ao conhecer?

Onde está o conhecimento

Que perdemos na informação?

T.S. Eliot 


\section{Considerações Finais}

Educar em uma sociedade da informação significa muito mais que treinar as pessoas para o uso das tecnologias de informação e comunicação: trata-se de investir na criação de competências suficientemente amplas que Ihes permitam ter uma atuação efetiva na produção de bens e serviços, tomar

decisões fundamentadas no conhecimento, operar com fluência os novos meios e ferramentas em seu trabalho, bem como aplicar criativamente as novas mídias, seja em usos simples e rotineiros, seja em aplicações mais sofisticadas.

Tadao Takahashi

\subsection{Síntese dos Primeiros Passos}

Esta pesquisa caracterizou-se pela exploração de um tema que ainda não está totalmente compreendido nem explicado, e cuja complexidade e abrangência exigiriam um conjunto de decisões por parte do pesquisador quanto a cortes no universo de pesquisa e na abordagem do referencial teórico.

A falta de compreensão tem seu início na forma como a literatura tem tratado a biblioteca não-presencial, sem ter ainda chegado a um consenso em relação às definições. Durante a pesquisa encontrei, aproximadamente, duas dezenas de definições relativas ao tema que variam entre termos como: biblioteca virtual, biblioteca digital, biblioteca eletrônica, biblioteca biônica e biblioteca de realidade virtual. Acabei adotando como referencial a nomenclatura definida no I Seminário da Rede de Bibliotecas Virtuais do Prossiga e que é apresentada no capítulo 1 deste documento.

Embora o referencial teórico tenha sido orientado para os objetivos e as hipóteses definidas para a pesquisa, é possível reconhecer que a perspectiva da chamada "biblioteca virtual" implica diferentes abordagens e impactos que, por assim dizer, percorrem vários aspectos de busca e recuperação de informações, tais como: as idéias apresentadas por Gianesi e Correa (1984), Freire (1986), Kuhlthau (1983) até encontrarmos Dervin (1983) que por meio da abordagem "Sense-Making" faz um 
estudo da necessidade de informação sob a ótica do usuário, demonstrando a necessidade de deslocarmos a ênfase de análise no sistema para a necessidade de concentrarmos o estudo no usuário.

Além da análise do processo de busca e recuperação de informação, outros dados foram alvo desta pesquisa, sendo sistematizados e apresentados de acordo com o modelo "ACTIONS", desenvolvido por Bates em 1995. Por meio deste modelo, indivíduos interessados em Educação a Distância podem analisar e definir qual a melhor tecnologia a ser utilizada para a função de ensino-aprendizagem a distância que se deseja oferecer.

Os resultados da pesquisa foram agrupados e analisados a partir de quatro perspectivas, a fim de determinar:

\footnotetext{
* Quem é o usuário da Bibvirt?

* Quais são as funções de aprendizagem relacionadas à Bibvirt, apresentadas pelo usuário?

* Como é seu processo de busca de informação no site?

* Como o usuário recupera informação?
}

Não podemos dizer que a amostra dos resultados da pesquisa é representativa, pois o número de acessos diários ao site (uma média de 5.140 acessos/dia) é bem maior do que o retorno de questionários respondidos que obtive (528 questionários em 5 meses). Como o preenchimento era opcional, não havendo nenhum vínculo com a navegação no site, podemos dizer que os resultados representam uma primeira impressão dos usuários. Mesmo assim, a análise dos resultados ajudou na elaboração do novo lay-out do site e na reestruturação do processo de busca e recuperação de informação.

\subsection{Usuários da Internet no Brasil}

As estimativas do número de usuários da Internet no Brasil têm oscilado muito devido à diversidade de fontes de pesquisa e critérios adotados por elas. Algumas destas fontes estão diretamente relacionadas a provedores de acesso que fazem a contagem por amostra representativa de acesso a esses provedores e outras que 
fazem pesquisa de campo fazendo um levantamento de dados nas diferentes regiões brasileiras. Com isso, o número estimado de usuários da Internet no Brasil tem variado de 17 milhões a 23 milhões de usuários.

Qualquer que seja o critério, entretanto, tem sido invariável o perfil do usuário que acessa à rede. Em uma das pesquisas, utilizada como referência nesta dissertação e apresentada anteriormente, temos que o usuário da Internet é jovem (57\%), predominantemente do sexo masculino (58\%), com renda familiar superior a $\mathrm{R} \$ 1.260,00(50 \%)$ e pertencentes a classe A/B (60\%). Do total de entrevistados, também temos que $27 \%$ são estudantes da Educação Básica ${ }^{76}$.

A primeira impressão do usuário da Bibvirt confirma esses dados. O usuário da Bibvirt também é, em sua maioria, jovem (53\%), do sexo masculino $(50,7 \%)$ e com renda familiar superior a $\mathrm{R} \$ 1.200,00$ (82,4\%). Os estudantes da Educação Básica representam $37,8 \%$ dos usuários.

Pela pesquisa também temos que uma parcela significativa dos usuários da Bibvirt é representada por estudantes universitários (23,8\%). Esse fato se justifica pelo tipo de informação encontrada em seu acervo. A Bibivirt dispõe de um acervo variado que inclui, além de diversos clássicos da Literatura Brasileira, pedidos no exame vestibular, um banco de sons de aves e instrumentos brasileiros, personalidades da nossa História em discursos significativos para a vida do País, além de diversas outras informações que interessam a grupos diferentes de usuários.

Do resultado apresentado pelas diferentes pesquisas, inclusive a colocada no site da Bibvirt, podemos ver que a Internet no Brasil ainda é restrita a elite e que há a necessidade urgente de sua popularização, evitando mais uma forma de exclusão social, chamada de exclusão digital. Apesar do número de venda de computadores no Brasil ter crescido 22\% no ano de 2001 e deva avançar mais 11\% neste ano (dados da Veja On-line - edição 1735 - 23 de janeiro de 2002) e o crescimento no número de ofertas de acesso gratuito à rede também, decorrente da competitividade,

\footnotetext{
${ }^{76}$ Educação Básica é a representada por estudantes de Ensino Fundamental I, Il e Médio de escolas Públicas e Particulares em todo Brasil.
} 
o acesso ainda deve continuar restrito devido às altas tarifas cobradas pelas empresas telefônicas.

É papel do Estado evitar a exclusão digital, incorporando os segmentos sociais menos favorecidos e de baixa renda à sociedade da informação. Nos últimos anos novas propostas têm surgido com o objetivo de acelerar a incorporação dos cidadãos às novas formas de organização social introduzidas pela tecnologia, mas poucas já foram realmente colocadas em prática.

Uma das mais importantes surgiu em abril de 1997, na criação do PROINFO (Programa Nacional de Informática na Educação), com a intenção de formar 25 mil professores e atender a 6,5 milhões de estudantes em 44,8 mil escolas públicas por todo País, através da compra e distribuição de 100 mil computadores ligados à Internet. No entanto, até o final de 2001, segundo notícia veiculada no jornal "Correio Brasiliense" de 27 de dezembro de $2001^{77}$, só foram repassadas 23,4 mil máquinas (20\%) para 2,8 mil centros de ensino, sendo que em muitos destes centros os professores não haviam sido capacitados. Em 1998, o ministro Paulo Renato Souza anunciou que, pelas contas dos técnicos do ministério, o programa precisava de $\mathrm{R} \$$ 450 milhões para levar 100 mil computadores às escolas de ensino fundamental. Metade do dinheiro viria do Banco Mundial (Bird) e o restante dos cofres da União. Entre 1997 e 2001, para completar a primeira etapa do programa, foram liberados apenas R\$ 113 milhões. O valor não é nem a metade do dinheiro necessário para encerrar as três etapas do programa - levando em conta as previsões iniciais, sem contar o aumento de preço das máquinas. No orçamento do ano que vem, que só deve ser aprovado no início de 2002, estão previstos $\mathrm{R} \$ 34,5$ milhões para compra de novos equipamentos e R\$ 500 mil para a capacitação de professores. Esse dinheiro será destinado para a entrega, ainda no primeiro semestre, dos computadores da segunda etapa do projeto. Devemos esperar para ver...

Mas, mesmo sem ter cumprido as metas do Proinfo, o MEC em parceria com o Ministério das Comunicações, lança um projeto ainda mais ambicioso. Este projeto

\footnotetext{
${ }^{77}$ A matéria "Estudantes à espera de computadores" publicada no jornal "Correio Brasiliense" de 27 de dezembro de 2001, encontra-se disponível on-line na URL

<http://www2.correioweb.com.br/cw/2001-12-27/cab 103956.htm> [02.02.2002]
} 
tem como meta equipar todas as escolas públicas brasileiras, de ensino médio, com computadores ligados à rede Internet até o final de 2002. Seu financiamento é feito pelo FUST (Fundo de Universalização dos Sistemas de Telecomunicações para Educação) e ainda no primeiro semestre de 2001, enfrentou complicações quando no edital de licitação para a compra de computadores suspeitou-se de favorecimento da Microsoft. A correção foi feita com a inclusão da possibilidade da escola escolher o sistema operacional Linux, no lugar do Windows, da Microsoft. No entanto, outro problema surgiu relacionado à licitação dos computadores. Pela informação veiculada no Jornal "O Estado de São Paulo" de 12 de janeiro de 2002, Pg. A11, há um erro no Orçamento Geral da União de 2002, aprovado em dezembro pelo Congresso, impedindo a licitação do serviço.

Outra iniciativa também importante que continua parada é a prevista dentro do projeto "Uma Biblioteca em cada Município" do Ministério da Cultura, onde pelo edital podemos ver que cada uma das novas bibliotecas está automaticamente inscrita no "Programa de informatização das Bibliotecas Públicas", que irá acontecer em parceria com o programa "Sociedade da informação" (sediado no Ministério da Ciência e Tecnologia), o Ministério das Telecomunicações, o Fundo de Universalização das Telecomunicações (FUST), a Comunidade Solidária, o Ministério da Cultura e a Biblioteca Nacional. A julgar pelos parceiros e o envolvimento deles em outros programas de informatização que já tive oportunidade de mencionar anteriormente, a viabilização deste programa não acontecerá tão cedo.

Levando em consideração que as bibliotecas são equipamentos sociais de uso coletivo e que em nosso País o acesso à Internet ainda é caro para o cidadão individualmente, deve-se cobrar do governo a iniciativa de torná-la uma tecnologia de uso coletivo, multiplicar e potencializar o acesso a informações e aplicações para toda uma coletividade.

Outra alternativa que está sendo implementada em algumas regiões brasileiras é a montagem de pontos de acesso público à Internet (Telecentros). Telecentro tem sido o termo genérico utilizado para denominar as instalações que prestam serviços de comunicações eletrônicas para camadas menos favorecidas da população, 
especialmente nas periferias dos grandes centros urbanos ou mesmo em áreas mais distantes. A Escola do Futuro da Universidade de São Paulo faz parte da implementação do trabalho de alguns Telecentros na grande São Paulo, sob a supervisão de Carlos Seabra.

Uma iniciativa mais antiga, que também é um projeto da Escola do Futuro da USP, é o Mutirão Digital. O projeto acontece com o apoio do Rotary Clube e tem por finalidade equipar o maior número possível de escolas públicas com computadores ligados à Internet, alguns softwares básicos, instrutores e capacitação de pelos menos dois professores de cada escola. Até o momento já foram distribuídos 600 computadores para escolas paulistas e, só não foi um número maior, devido à falta de colaboração da Secretaria Estadual de Educação de São Paulo.

Quando todas essas alternativas forem realmente viabilizadas, ampliará a oportunidade de acesso a produtos e serviços já disponíveis na rede, dentre eles a Biblioteca Virtual do Estudante Brasileiro, auxiliando desta forma a suprir a escassez de informações em pequenas comunidades por todo Brasil.

\subsection{A Dinâmica de Organização e Ampliação do Acervo}

Em qualquer Nação o desenvolvimento cultural tem papel fundamental na formação social, econômica e política de seus cidadãos, representada principalmente pela competência que eles têm para ler, escrever e interpretar símbolos.

Coprani ${ }^{78}(1998)$ comenta que o hábito de leitura de um povo não pode ser comparado a sua alfabetização. "Saber ler não é suficiente para ter-se familiaridade ou convívio permanente com a leitura -- para obter aquilo que em inglês se chama literacy.". Para se ter essa competência é necessário o contato diário com os livros.

Mas, o livro é caro no Brasil, principalmente se comparado a preços internacionais. O fator principal é a baixa tiragem. No exterior a tiragem de um livro gira em torno de 30 mil cópias e no Brasil, por volta de 3 mil cópias. Esse resultado é reflexo da falta de pontos de vendas (livrarias) e desinteresse de muitas bibliotecas em ampliar seu

\footnotetext{
${ }^{78}$ COPRANI, O. Livro, Biblioteca e Leitura no Brasil. Brasília: 1998. Available from Internet <URL: http://www.minc.gov.br $>$ [15.01.2002]
} 
acervo. Esse fato leva também a um outro problema. Pela reportagem veiculada na Gazeta Mercantil de 16 de julho de 2001, Pg. A-8, temos que $16 \%$ da população detêm $73 \%$ de todos os exemplares adquiridos no País e a maioria destes leitores têm mais de 30 anos.

Só para se ter uma idéia, hoje no Brasil temos aproximadamente 1.200 livrarias, concentradas principalmente no eixo Rio - São Paulo, e 3.600 bibliotecas quando o ideal seria, para uma população de 170 milhões de habitantes, um mínimo de 17.000 livrarias e uma biblioteca pública em cada município. Hoje temos cerca de 5.500 municípios. (Weffort $\left.{ }^{79}, 1998\right)$.

O acervo da Bibvirt compõe-se principalmente de textos integrais de obras literárias, livros didáticos e paradidáticos, imagens, sons, artigos e documentos históricos. Ali se encontram, entre outros materiais, dezenas de obras de Literatura Brasileira e Portuguesa, e em breve de Literatura Estrangeira (Projeto Gutenberg) ${ }^{80}$, a coleção de livros do Telecurso 2000, sons de aves e instrumentos musicais brasileiros, vozes de diversas personalidades em discursos históricos, artigos sobre Educação e parte do acervo permanente do Museu de Arqueologia e Etnologia da Universidade de São Paulo.

Disponibilizar gratuitamente vasta quantidade de informação textual e audiovisual qualificada, atualizada e facilmente acessível via Internet é uma das missões da Bibvirt e que pode contribuir para o desenvolvimento cultural de nosso País.

O acervo da Bibvirt poderia ser bem mais completo e atender melhor a demanda dos usuários. Porém, devido à lei $n^{\circ} 9.610$, relativa aos Direitos Autorais que foi atualizada e revisada em 19.02.1998, muitas restrições foram feitas, dificultando a

\footnotetext{
${ }^{79}$ WEFFORT, F. Quatro objetivos da Cultura. Revista Fiesp (05.03.1998). Available from Internet $<$ URL:http://www.minc.gov.br > [15.01.2002]

${ }^{80}$ O Projeto Gutenberg talvez seja a mais conhecida das diversas iniciativas de disponibilizar na Internet (através de trabalho voluntário e de doações) os textos completos de livros cujos direitos autorais encontram-se vencidos. Tal projeto pretende, até 31 de dezembro de 2001, colocar gratuitamente à disposição dos usuários da rede milhares de textos eletrônicos. Estes documentos são disponibilizados em ASCII, uma vez que, conforme observa Michael Hart, o organizador do projeto, sistemas operacionais e programas se obsoletizam, mas plain vanilla text não. http://www.promo.net/pg/
} 
publicação de materiais que não tivessem em domínio público ou possuíssem a autorização prévia dos seus responsáveis.

Com isso, o acervo da Bibvirt é restrito, pois muitas obras relevantes não têm autorização dos autores/editoras para serem publicadas, como é o caso, por exemplo, das obras de Monteiro Lobato que não são autorizadas pela família e as obras de Shakespeare contemporâneas traduzidas para o Português. Algumas tentativas têm sido feitas junto às editoras/autores com a finalidade de ampliação do acervo, tais como a possibilidade de disponibilizar sumários, prefácios e talvez até alguns capítulos de obras, como divulgação e mesmo estímulo à leitura. Além da questão dos direitos autorais, outros fatos considerados na seleção do material e sites recomendados são:

* Adequação aos propósitos e ao público-alvo da Biblioteca;

* Idioma (Língua Portuguesa);

* Relevância e utilidade para o usuário;

* Qualidade, atualidade e confiabilidade da informação;

* Presença de conteúdo significativo, de fácil compreensão e utilização;

* Interatividade com o usuário;

* Boa apresentação e atratividade visual.

Diante de todas essas questões, poderíamos imaginar que o acervo da Bibvirt fosse restrito, não atendendo a demanda apresentada pelo usuário. Mas, pela pesquisa colocada no site, $44,1 \%$ dos entrevistados afirmaram encontrar a informação que estavam procurando e $57 \%$ afirmaram que essa informação continha exatamente o que queriam.

\subsection{O Desafio da Formação Tecnológica}

Outros dois tópicos abordados na pesquisa foram relativos à análise do processo de busca e recuperação de informações vivenciada pelo usuário, quando visitam o site. Para definição das questões que iriam compor esses tópicos levou-se em consideração as idéias de Taylor(1984), que defende o enfoque no problema 
individual dos usuários, devendo considerar qual dado um indivíduo quer encontrar no sistema de informação, que uso fará dele e como o sistema pode melhor ser projetado para preencher sua necessidade de informação e Dervin (1983) sustentando que qualquer tentativa de descrever padrões de busca de informação deve admitir o indivíduo como o centro do fenômeno e considerar a visão, necessidades, opiniões e dificuldades desse indivíduo como elementos significantes e influentes que merecem investigação.

A partir das idéias de Taylor e Dervin, as questões presentes no questionário colocado na Bibvirt foram direcionadas para identificar as dificuldades no processo de busca e recuperação de informação, vivenciadas pelos usuários, quando visitam o site. As respostas mostraram, em primeiro lugar, que a maior parte dos usuários $(44,1 \%)$ não encontra dificuldade para localizar as informações no acervo apesar de a maioria preferir que o acervo fosse estruturado de outra forma, como, por exemplo, de acordo com as três grandes áreas do conhecimento: exatas, humanas e biológicas. As sugestões foram acatadas e o acervo foi dividido não só pelas três áreas do conhecimento, mas também de acordo com as diferentes mídias disponíveis. Somente o material do projeto Gutemberg não entrou na divisão por possuir todas as mídias (textos, sons, imagens e vídeos).

Um aspecto relevante na análise do processo de busca de informação é a constatação da falta de orientação que alunos dos diferentes graus de ensino recebem quando buscam informações na Internet. Como podemos ver na análise dos dados da pesquisa, $47 \%$ dos estudantes entrevistados que freqüentam escolas públicas possuem, nessas escolas, computadores ligados à Internet. O número não é muito diferente nas escolas particulares onde o número de computadores ligados à Internet chega a ser representado por $77 \%$ dos estudantes. Mas, somente $44 \%$ dos estudantes de escolas particulares que responderam a pesquisa e $50 \%$ dos estudantes das escolas públicas afirmaram que seus professores incentivam a busca de informações em ambientes virtuais.

Quanto ao tipo de incentivo dado à pesquisa, os estudantes, de uma maneira geral, responderam que $57,3 \%$ dos professores somente pedem a pesquisa na Internet sem oferecer nenhuma fonte como referência, $25,4 \%$ afirmaram que recebem 
algumas sugestões de fonte, mas não têm nenhum acompanhamento e somente 17,3\% afirmaram que o professor acompanha o processo de busca e recuperação de informações em ambientes virtuais junto com seus alunos. Isso demonstra que há a necessidade de formação dos professores com a finalidade de conhecerem as metodologias para pesquisa em ambientes virtuais e poderem orientar seus alunos para que façam uso efetivo dos recursos tecnológicos.

A Bibvirt não tem como objetivo prestar esse tipo de serviço, por isso conta com o apoio de um outro projeto da Escola do Futuro da USP destinado a essa finalidade. Este outro projeto, intitulado Webquest (www.webquest.futuro.usp.br), define-se como uma metodologia para engajar alunos e professores no uso da Internet voltado para o processo educacional, estimulando a pesquisa, o pensamento crítico, o desenvolvimento criativo da atividade docente do professor, a produção de materiais e o protagonismo juvenil. Com tais premissas, alunos e professores poderão encontrar informações com mais facilidade, recuperá-las de uma forma mais segura e garantir a obtenção de resultados mais satisfatórios.

As análises históricas das diferentes estratégias de presença de acervos de bibliotecas na Internet indicam claramente a tendência em direção à edição, publicação e conversão de documentos de papel para a mídia eletrônica, bem como o aumento da importância relativa dos recursos disponíveis na rede em contraste com aqueles disponíveis somente no acervo das bibliotecas presenciais. Se essa é a realidade, é somente por meio de ações efetivas para formação de usuários competentes para lidar com processos de busca e recuperação de informações em ambientes virtuais que será possível evitar a exclusão digital.

Como diz o economista e jornalista Gilson Schwartz, do Instituto de Estudos Avançados da USP, "exclusão digital não é ficar sem computador ou telefone celular. É continuarmos incapazes de pensar, de criar e de organizar novas formas - mais justas e dinâmicas - de produção e distribuição de riqueza simbólica e material. 0 resultado poderá ser uma espécie de - apartheid mental -, caracterizado pela exclusão radical de uma grande parcela da humanidade da era da informática." 


\subsection{As Oportunidades de Aprendizagem}

As funções de aprendizagem relacionadas à Bibvirt estão, de alguma forma, ligadas à facilidade no processo de busca e recuperação de informações que provém da interatividade do usuário com o ambiente e da sua capacidade de interpretação das informações apresentadas. A informação é tudo aquilo que flui através do hardware $^{81}$, e é apresentada por meio de um conjunto de idéias, noções, argumentos, conhecimentos, juízos, pesquisas, debates, sínteses, análises e saberes que só podem ser criados, consolidados e transmitidos a partir do momento que são oferecidas condições para que sejam interpretados.

Avaliando a Bibvirt, percebe-se que ela busca e recupera informações por meio de palavras-chave ou de formulário (ajuda da equipe da Bibvirt), fornecendo como retorno informação em diferentes mídias e formatos evidenciando, assim, seu caráter interativo. A interatividade permite que o usuário "navegue" de acordo com suas necessidades, sem uma seqüência pré-definida, favorecendo o seu processo de busca de informações orientado por suas inquietações (lacunas).

Esse é o primeiro passo para determinar as funções de aprendizagem relacionadas a qualquer processo. Em um segundo momento é necessário analisar a forma como foi conduzida a interpretação das informações encontradas e o quão significativa ela foi para o usuário. Infelizmente, na leitura dos dados apresentados pela pesquisa só foi possível identificar o que o usuário fez com a informação, mas não deu para aprofundar na análise das funções de aprendizagem relacionadas ao site.

\subsection{Além das Paredes da Bibvirt}

Um dos fatores que me conduz ao questionamento da importância das bibliotecas virtuais e a necessidade de capacitar alunos e professores em processos de busca de informação, em ambientes eletrônicos ou não, está relacionado com as idéias apresentadas por Litto ${ }^{82}$ (1996), em um de seus trabalhos reportando ao estudo de

\footnotetext{
${ }^{81}$ OLIVEIRA, R. S. Minidicionário Compacto de Informática. São Paulo: Editora Rideel. 1999. Hardware - Parte física de um sistema informático (equipamentos, placas, cabos, fiações, periféricos, etc).

82 LITTO, F. Repensando a educação em função de mudanças sociais e tecnologias recentes. In: Vera Barros de Oliveira, org., Informática em Psicopedagogia. São Paulo: Senac, 1996. Pg. 85-110.
} 
Robert Reich, no qual comenta que existirão três grandes categorias de trabalho: serviços rotineiros de produção, serviços feitos pessoa-a-pessoa e serviços analítico-simbólicos. O tipo de Educação que oferecemos na escola hoje em dia será suficiente para aqueles que pretendem trabalhar nas primeiras duas categorias.

No caso do estudante desejar fazer parte da terceira categoria, que contribuirá para a competitividade e o bem-estar da nação, não encontrará escolas adequadas ao desafio de sobrevivência na sociedade da informação que se the apresenta num futuro breve.

Se levarmos em consideração que os profissionais que trabalharão em serviços analítico-simbólico lidarão com a manipulação de símbolos (dados, palavras, representações orais e visuais) em três tipos de atividade: a solução de problemas, a identificação de problemas e agenciamento estratégico, e que utilizarão como ferramenta algoritmos matemáticos, argumentos legais, princípios científicos, discernimentos psicológicos e sistemas de persuasão, temos que pensar que a escola deve mudar, passando do enfoque da transmissão de conteúdos para o enfoque do desenvolvimento de competências e habilidades, dentre elas a busca, interpretação e disseminação de informações na Internet.

Os profissionais nesta categoria, como apresentado por Litto (1996), são cientistas, engenheiros, executivos de relações públicas, banqueiros, advogados, contadores criativos, arquitetos, consultores de todos os tipos, jornalista, editores e professores universitários. "A natureza de seu trabalho será de simplificar a realidade, em imagens abstratas que podem ser recombinadas, experimentadas e comunicadas a outros especialistas, e depois transformadas de volta à realidade".

Diante disto, torna-se necessário alertar para a especificidade do papel dos professores e bibliotecários face às barreiras e dificuldades ainda bastante presentes no uso de recursos eletrônicos disponíveis na Internet. Tais dificuldades prendem-se ao desconhecimento de aplicação destes recursos e serviços, às barreiras lingüísticas, legais, políticas, culturais e econômicas, e ainda a problemas relacionados à questão tecnológica. 
Assim como ao professor, cabe aos demais profissionais envolvidos em processos de busca e recuperação de informações na rede, entender, decodificar e atuar criticamente, auxiliando aos interessados a selecionar, adquirir, e preservar os recursos armazenadores e distribuidores da informação também no ambiente eletrônico, garantindo aos alunos o direito e todas as oportunidades decorrentes do caráter interativo da Internet, evitando a exclusão digital.

Encerro aqui a análise dos dados resultantes da opinião dos usuários que responderam à pesquisa colocada no site, bem como o levantamento de informações relacionadas ao tema. Tudo isso não seria válido se não considerasse as bibliotecas brasileiras, incluindo as que estão na Internet, como uma das instituições sociais reconhecidamente responsáveis pela preservação da herança cultural e administração de sistemas de informação científico-tecnológicos do País.

Particularmente, reafirmo que a Biblioteca Virtual do Estudante Brasileiro integra este cenário. A exemplo dela, todas as instituições envolvidas com Educação e Pesquisa, nos setores público e privado, deveriam se comprometer a apoiar iniciativas de desenvolvimento de banco de dados eletrônicos, além de fornecer acesso a qualquer cidadão, ajudando a atenuar a exclusão digital, entendida aqui não só como a falta de oportunidades de acesso à recursos tecnológicos, mas também a falta de competências e habilidades para lidar com eles e suas atividades relacionadas.

Somente desta forma teremos uma nação desenvolvida, onde seus cidadãos possuem competências e habilidades de busca de informação, leitura e interpretação de textos, que são as bases para a formação de pessoas críticas, formadoras de opinião e capazes de exercer sua Cidadania. 


\section{REFERÊNCIAS}




\section{Referências Bibliográficas Citadas}

- ALMEIDA, M. Informática e Formação de Professores. Secretaria de educação a Distância. Brasília: Ministério da Educação, Seed. 2000. 192 p.

* AVANCINI, M.; CAFARDo, R. Censo Escolar. São Paulo: Jornal "O Estado de São Paulo". 28 de junho de 2001. Pg. A12.

- BATES, T. Technology, Open Learning and Distance Education. New York: Routledge Studies in Distance Education, 1995. 266 p.

* BAPTISTA, C. A dor de nunca saber o bastante. Revista Veja, São Paulo, Edição 1716, 5 de setembro de 2001.

* BUSH, V. As we may think. The Atlantic Monthly. n. 176, p. 101-108, July 1945. Available from Internet:

$<U R L:$ http://www.notredame.ac.jp/ftplib/Articles/CMC/bush45.txt> e $<$ URL:http://www.isg.sfu.ca/ duchier/misc/bush> [01 Dec. 2001].

* COPRANI, O. Livro, Biblioteca e Leitura no Brasil. Brasília: 1998. Available from Internet <URL: http://www.minc.gov.br > [15.01.2002]

* CORREA, H. L.; GIANESI, I.G.N. Administração estratégica em serviços. São Paulo: Atlas, 1994. 233 p.

- DERVIN, B. An overview of Sense-Making research: concepts, methods and results to date. (on line) In: International Communications Association's Annual Meeting. Dallas: May, 1983. Available from Internet:

<URL:http://www.eca.usp.br/prof/sueli/sm1983 4.html> [01 Dec. 2001]

- DERVIN, B. Chaos, Order and Sense-Making: A proposed theory for information design. In: JACOBSON, R. ed. Information Design. Cambridge, MA: MIT Press, 1999.

* DERVIN, B.; NILAN, M. Information needs and uses. In: M. Williams, ed. Annual Review of Information Science and Technology, v.21, p. 3-33, 1986.

- DOWLIN, K. E. The electronic library: the promise and the process. New York: Neal-Schuman, 1984. 199 p. ISBN 091-8212-758.

- ELLISON, L. Interviewer: Daniel Morrow, Executive Director, The Computerworld Smithsonian Awards Program. 24 October 1995. Available from Internet <URL: http://http://americanhistory.si.edu/csr/comphist/le1.html> [15.12.2001]

* FerReIRA, S.M.S.P. Design de Biblioteca Virtual Centrado no Usuário. Ciência da Informação On-line. Brasília, v.26, nº 2. 1997. 

A abordagem Sense-Making. Janeiro, 1998. Available from Internet: <URL:http://www.eca.usp.br/nucleos/sense/oque.htm>. [01 Dec. 2001] - FERREIRA, M; COSTA, M. A Escola do Futuro e as Novas Tecnologias Aplicadas à Educação. São Paulo: Revista de Educação e Informática. Fundação para o Desenvolvimento da Educação - FDE. Ano 3. Nº8. Pg.26.1992.

- FREIRE, madALENA. Sobre tarefa e construção do conhecimento. Série cadernos de reflexão. São Paulo: Espaço Pedagógico, 1986.

* GOMES, S. L. R. et. al. Bibliotecas virtuais na Internet: a experiência do Prossiga: Revista Ciência da Informação V.25, n³, 1996.

* GRIfFIN, S. Internet Pioneers. Chapel Hill, 2000. Available from Internet <URL:http://www.ibiblio.org/pioneers/andreesen.html > [16.12.2001]

- HILL, A. G. "The storage, processing and communication of information". In: Bibliography in an Age of Science. Urbana (IL): University of Illinois Press, 1951. p. 73-90.

- KRETZ, F. Dialogue, Service. Interactivité et Sés Composantes: aspects de conception et d'évaluation. Bulletin de L'IDATE. Paris: Centro Georges Pompidou, $\mathrm{n}^{\circ}$ 11, abril, 1983. In: Silva, M. Sala de aula interativa. Rio de Janeiro: Editora Quartet. 2001. pg. 86

- KUHLTHAU, C. C. Seeking Meaning: a process approach to library and information services. Norwood, NJ: Ablex, 1983.

* LICKLIDER, J. C. R. Libraries of the future. Cambridge (Mass.): MIT Press

- LICKLIDER, J.C.R. Man-Computer Symbiosis, 1960. Available from Internet: $<U R L$ : http://livinginternet.com/i/ii licklider.htm > [15.12.2001]

* LÉVY, P. As tecnologias da inteligência. O futuro do pensamento na era da informática. RJ: Editora 34, 1993.

* LÉVY, P. Cibercultura. São Paulo: Editora 34. 1999. 260 p.

- LITTO, F. et. al. Videotexto e responsabilidade social no terceiro mundo. In: Comunicação e novas tecnologias. Editora Com-Arte. Escola de Comunicações e Artes. Universidade de São Paulo. S. Paulo. 1984. 59 p.

* $\quad$ LITTO, F. Anais do Fórum Mineiro de Educação. Uberlândia. MG.

* LITTO, F. A Escola do Futuro e as Novas Tecnologias Aplicadas à Educação. São Paulo: Revista de Educação e Informática. Fundação para o Desenvolvimento da Educação - FDE. 1992. 
* LITTO, F. Pitfalls and promises: using the Internet to Create Virtual Classrooms in the Third World. In: Distance Learning and New Technologies in Education Proceedings of the First International Conference on Distance Education in Russia. Moscow: 5-8 July, 1994.

* LITTO, F. Repensando a educação em função de mudanças sociais e tecnologias recentes. In: Vera Barros de Oliveira, org., Informática em Psicopedagogia. São Paulo: Senac, 1996. Pg. 85-110.

* LITTO, F. Propriedade intelectual, novas tecnologias de Comunicação e Educação. Palestra dada no Congresso da ABED - Associação Brasileira de Ensino a Distância. Brasília: julho, 2001. Available from Internet $<$ URL:http://www.abed.org.br> [14.01.2002]

* MACHADO, Arlindo. Pré-cinemas e Pós-cinemas. Campinas-SP: Papirus, 1997.

* MARCHIONINI, G. Information Seeking in Electronic Environments. Cambridge: Cambridge University, 1998.

- MARCHIONINI, G.; KOMLODI, A. Design of Interfaces for Information Seeking. Annual Review of Information Science and Technology (ARIST), v.33, p. 89-130, 1998.

- MARCHIORI, P. Z. - Ciberteca ou biblioteca virtual? Uma perspectiva de gerenciamento de recursos de informação - Revista Transinformação. Publicação Quadrimestral. V.9, n², maio/agosto. 1997.

- MARCONDES, C. H.; GOMES, S. L. R. O impacto da Internet nas Bibliotecas Brasileiras. Revista Transinformação. Publicação Quadrimestral. V.9, n², maio/agosto. 1997.

* MARIA, E. Na cabeça do Internauta. São Paulo: Revista da Folha de São Paulo, 27 de setembro de 2001.

* NELSON, T. Xanadu. [ca. 1965] Available from Internet:

<URL:http://www.xanadu.net/xanadu/> [01 Dec 2001]

- OLIVEIRA, R. S. Minidicionário Compacto de Informática. São Paulo: Editora Rideel. 1999. 354 p.

- PARKER, E. B. The new communication media. In: Wallia, C. S., ed. Toward Century 21: technology, society and human values. New York: Basic Books, 1970. 
* PERROTtI, E. Biblioteca interativa. Revista "Conselho Federal de Biblioteconomia" $n^{\circ} 1$ de abril de 2001. Available from Internet

$<$ URL:http://www.cfb.org.br/atualizacao/basica.htm >. [14.01.2002]

* PIMIENTA, D. org. Lugar das Línguas Latinas na Internet. 2001. Available from Internet $<$ http://www.unilat.org/public/L5-PT.doc $>$ [14.01.2002]

- PLAZA,J. et. al. Comunicação e novas tecnologias. Editora Com-Arte. Escola de Comunicações e Artes. Universidade de São Paulo. S. Paulo. 1984. 59 p.

- POULTER, A. Building a browsable virtual reality library. Aslib Proceedings, v. 46, n. 6, p. 151, June 1994.

- REICH, R. O trabalho das Nações. São Paulo: Educator, 1994.

- RHODE, N F. Information needs. In: W. Simonton, ed. Advances in Librarianship, v.14 , p. 49-73, 1986. New York: Academic Press.

- TAKAHASHI, T. et. al. Sociedade da Informação no Brasil. Livro Verde. Brasília: Ministério da Ciência e Tecnologia. 2000. 203 p.

- TAYLOR, R. The Value-added Processes in Document-Based Systems:

Abstracting and Indexing Services. In: Information Services and Use. V.4. № 3. Pg. 127-46. 1984 June.

* VentuRI, J. De Alexandria à Internet. In: Revista Educação. Set, 2001. Pg. 96.

* WefFORT, F. Quatro objetivos da Cultura. Revista Fiesp (05.03.1998).

Available from Internet < URL:http://www.minc.gov.br > [15.01.2002] 


\section{Bibliografia Geral Levantada para a Pesquisa}

- ADONIS, C. Educación a Distancia através de las redes avanzadas. Available from Internet: <URL:http://www.doe.ds.ub.es/te/doctorado/95-/chrysos/introduc.html> [01 Dec 2001]

* BRAINTENBERG, V. Vehicles. Experiments in Synthetic Psychology. Cambridge, Mass.: MIT Press, 1984.

* BRAND, S. The Media Lab. Inventing the Future at MIT. New York: Viking, 1987.

- BRETZ, R. Media for Interactive Communication. Beverly Hills, Calif.: Sage, 1983.

* CAMILO, R. Guia Brasil 2000 - Quatro Rodas. São Paulo: Editora Abril, 2000.

- CAMPBELL, D. The Student's Guide to Doing Research on the Internet.

Reading. Massachusetts: Addisson - Wesley, 1995.

- CAMPBELL, J. Grammatical Man. Information, Entropy, Language and Life. New York: Simon \& Schuster, 1982.

- CANForA, L. A Biblioteca Desaparecida; Histórias da Biblioteca de Alexandria. São Paulo: Companhia das Letras, 1989. p.24

- CARTON, S. Internet Virtual Worlds. Quick Tour. MUDs, MOOs \& MUSHes: Interactive Games, Conferences \& Forums. Chapel Hill, North Carolina; Ventana, 1995.

* CHEMY, L.; REBA W. Gender and New Realities in Cyberspace. Seattle, Washington: Seal Press, 1996.

- CRONIN, M. J. Doing Business on the Internet. How the Eletronic Highway is Transforming American Companies. New York: Van Nostrand Reinhold, 1994.

- CUNHA, M. B. Biblioteca Digital: bibliografia internacional anotada. Revista Ciência da Informação On-line. Brasília: v. 28, número 3. 1999.

- DEmo, P. A Nova LDB - Ranços e avanços. Campinas: Papirus, 1997.

- DINIZ, P. Biblioteca do Futuro. Grupo de Bibliotecas Virtuais. Available from Internet: < URL:http://www.cg.org.br/gt/gtbv/artigo02.html> [01 Dec 2001]

- DRABENSTOTT, K. M.; BURMAN, C. M. Revisão analítica da Biblioteca do Futuro. Revista Ciência da Informação On-line, Brasília: V.26, nº 2.1997

* FerReIRA, J. R. A Biblioteca Digital. Revista USP. São Paulo (35): 46-53.

Setembro-Novembro 1997. 
* FerReIRA, S. M. S. P. Design de Biblioteca Virtual Centrado no Usuário. Ciência da Informação On-line. Brasília, v.26, nº 2. 1997.

* _. A abordagem Sense-Making. Janeiro, 1998. Available from Internet: <URL: http://www.eca.usp.br/nucleos/sense/oque.htm>. [01 Dec 2001] * FREIRE, M. Sobre tarefa e construção do conhecimento. Série cadernos de reflexão. São Paulo: Espaço pedagógico, 1986.

* GAllo, S. Guia do CBBS. Rio de Janeiro: Campus, 1992.

* GAtes, B. A Estrada do Futuro. São Paulo: Companhia das Letras, 1995.

* GOMES, M. T. Seja um alunauta e garanta seu futuro. 1997. Available from Internet: <URL:http://www.2.uol.com.br/exame> [01 Dec 2001]

* GOMES, S. L. R. et. al. Bibliotecas virtuais na Internet: a experiência do Prossiga Brasília: Revista Ciência da Informação V.25, n³, 1996.

* GONÇAlVES, C. T. F. Quem tem medo do Ensino a Distância?. Revista Educação a Distância, nº 7-8, INED/IBASE. 1996.

* GREENFIELD, P. M. O Desenvolvimento do Raciocínio na Era da Eletrônica. Os efeitos de TV, Computadores e Videogames. São Paulo: Summus, 1988.

* HACKOS, J.; REDISH, J.C. User and Task Analisys for Interface Design. New York: John Wiley, 1998.

* HERT, C. A.; MARCHIONINI, G. Seeking Statistical Information in Federal Websites: Users, Tasks, Strategies and Design Recommendations. S.L.P.: 1997. Available from Internet: <URL: http://www.glue.umd.edu/ dirg/b/sreport/bistoc.htm> [01 Dec 2001]

* JACOBSON R. Information Design. Cambridge: The MIT Press, 1999.

* KRETZ, F. Dialogue, Service. Interactivité et Sés Composantes: aspects de conception et d'évaluation. Bulletin de L'IDATE. Paris: Centro Georges Pompidou, $\mathrm{n}^{\circ}$ 11, abril, 1983. In: Silva, M. Sala de aula interativa. Rio de Janeiro: Editora Quartet. 2001.pg. 98

* KROL, ED. The Whole Internet. User's Guide \& Catalog. Sebastopol, Calif.: O’Reilly \& Associates, 1992.

* KRZYZANOWSKI, R. F. Ações para a construção de uma Biblioteca Virtual. Relato de Experiência do Sistema Integrado de Bibliotecas da USP. Revista USP. São Paulo (35): 54-61. Setembro/Novembro 1997.

* LAASER, W. Desenho de software para o Ensino a Distância. Available from Internet: <URL:http://www.interecto.net/ead/laaser2.htm> [01 Dec 2001] 
* LAQUEY, T.; RYER, J. C. The Internet Companion. Reading, Mass. AddisonWesley, 1993.

* LÉVY, P. Cibercultura. São Paulo: Editora 34. 1999. 260 p.

- LEWIS, C.; RIEMAN, J. Task-Centered User Interface Design: a pratical introduction. Boulder.: University of Colorado, 1994. Available from Internet: $<$ URL:http://www.amc.org/ perlman/uidesign.html> [01 Dec 2001] - LONGLEY, D.; MICHAEL S. N. Dictionary of Information Technology. $3^{\text {a }}$ ed. London: Macmillan Reference Books, 1989.

* LOYOLLA, W.; PRATES, M. Educação a Distância Mediada por Computadores - Uma proposta Pedagógica para a Pós-Graduação. Available from Internet: <URL:http://www.puccamp.br/ prates/index.html> [01 Dec 2001]

- MACHADO, Arlindo. Pré-cinemas e Pós-cinemas. Campinas-SP: Papirus, 1997.

* MINSKY, M. The Society of Mind. New York: Simon \& Schuster, 1985.

* MONLEVADE, J. Educação Pública no Brasil - Contos e Descontos. Brasília: Idéia, 1997.

* MONTEIRO, SILVANA D. A Forma Eletrônica do Hipertexto. Brasília: Revista Ciência da Informação On-line. v.29, n¹. 2000.

- MORRIS, R C T. Toward a User-Centered Information Science. Journal of the American Society for Information Science, v.45, n.1, p.20-30, 1994.

- NEgroponte, N. A Vida Digital. São Paulo: Companhia das Letras, 1995.

- PEREIRA, M. N. F. Bibliotecas Virtuais: realidade, possibilidade ou alvo de sonho. Brasília: Revista Ciência da Informação. Vol. 24, nº 1. 1995.

- POHLMANN F. O.; CAMPOS, M. B.; RAABE, A. Guia para criação de Bibliotecas Virtuais. Available from Internet:

<URL:http://www.cglobal.pucrs/bibdigital/kits/kit1.htm> [01 Dec 2001]

- REICH, R. O trabalho das Nações. São Paulo: Educator, 1994.

- ShNEIDERMAN, B. Designing the User Interface: Strategies for Effective Human-Computer Interaction. 3 ed. Massachusetts: Addison-Wesley, 1998.

- SPENNMANN, D. H. R. On-line study packages for distance education. 1997.

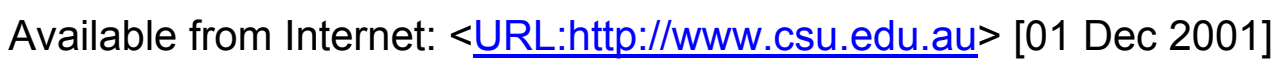


ANEXOS 


\section{Anexo 1}

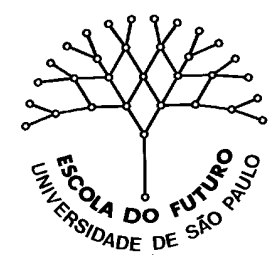

UNIVERSIDADE DE SÃO PAULO

Núcleo de Pesquisa das Novas Tecnologias de Comunicação Aplicadas à Educação

\section{A ESCOLA DO FUTURO}

Fredric Michael Litto

\section{SUMÁRIO EXECUTIVO - BIBLIOTECA VIRTUAL DO ESTUDANTE BRASILEIRO}

A presente proposta sugere a criação de uma "Biblioteca Virtual para o Estudante Brasileiro", para ser acessada a partir das escolas ou de residências brasileiras através da Rede Nacional de Pesquisas (Internet) ou através de linhas discadas de telefonia, que tornaria acessíveis, na Língua Portuguesa, e sem custo para o usuário, todos os recursos (textos, gráficos, imagens e sons) que uma equipe de educadores brasileiros julgar apropriados para estudantes de escolas de primeiro e segundo graus e de escolas técnicas do País. Na "Biblioteca Virtual" teríamos três seções principais: (1) obras em domínio público, digitalizadas para esse Projeto; (2) gateways para bases de dados brasileiros já existentes, com informações apropriadas para uso educacional e disponíveis a custo zero; e (3) CD-ROMs de material brasileiro apropriado para uso educacional, tornado disponível por seus produtores a custo zero, como forma de marketing. Acredita-se que a existência de tal "Biblioteca Virtual", acompanhada pela oferta simultânea de modelos de atividades para estudantes e professores, tanto de natureza curricular como extracurricular, e fazendo uso da informação na "Biblioteca", aumentaria a motivação do usuário e cultivaria práticas heurísticas. Dando a estudantes e professores acesso a um vasto depósito de informação atualizada e de fácil consulta, espera-se acelerar o processo de modernização na educação brasileira. A "Biblioteca" uma vez formada e funcionando, ajudará a reduzir o isolamento das comunidades rurais e pequenas pelo Brasil afora e ajudará a desenvolver recursos humanos para a era da informação, tanto no local do proponente como entre jovens usuários do sistema. Especialistas em Educação a Distância da University of British Columbia (Canadá), aceitaram a incumbência de acompanhar o projeto desde o seu começo, oferecendo 
apoio na faceta específica de avaliação educacional, particularmente no componente custo-benefício de educação a distância.

\section{Conhecimento do Problema}

Embora o Brasil esteja entre as dez principais economias do mundo, foi somente nos últimos anos que começou a fazer, em educação, investimentos necessários para preparar seus jovens para o tipo de trabalho intensivo-em-conhecimento que terão de enfrentar nas próximas décadas.

A introdução de computadores na educação em todos os níveis está se dando num ritmo que, na opinião de fontes abalizadas, é inadequado para garantir uma geração adequadamente preparada de mão de obra para negócios, indústria e agricultura nos próximos anos. As instituições privadas nos níveis de primeiro e segundo graus por todo o país têm, nos últimos dois ou três anos, adquirido equipamentos para a introdução de computadores no currículo, mas têm sido excessivamente modestas nos seus investimentos na preparação de professores e, mais ainda em ir além das atividades de nível de entrada como software tutorial, trabalho simplista com gráficos, e jogos. As escolas públicas, quase sem exceção, estão lamentavelmente atrasadas, não tendo nem equipamentos nem professores alfabetizados em computação. Esta situação se deve a muitos fatores de natureza econômica, ideológica e cultural. A língua portuguesa, embora falada por aproximadamente 200 milhões de pessoas no mundo, infelizmente não foi a escolhida como segunda ou terceira linguagem para mídia computadorizada, por aqueles que preparam software educacional a nível internacional. Igualmente, cursos de inglês exigidos por quase todos os currículos escolares no Brasil, são rudimentares e inadequados para permitir navegar em ambientes eletrônicos em língua inglesa. O resultado é que 0 fator motivação para "computer literacy", da parte dos estudantes, professores e pais, não é funcional como deveria ser. $E$ a menos que se tome medidas urgentes, a modernização da educação no Brasil ficará fora de compasso com as necessidades da sociedade. 


\section{Descrição do Projeto}

\section{Objetivos}

Esse Projeto visa criar uma "Biblioteca Virtual para o Estudante Brasileiro", isto é, um vasto depósito de informação apropriada para estudantes em escolas técnicas, e de primeiro e segundo graus, com livre acesso por meio de conexões discadas para aqueles que vivem dentro do raio de um telefonema local da Universidade de São Paulo, e via Internet (a Rede Nacional de Pesquisa) para outros, por todo o País.

O "backbone" da Rede Nacional de Pesquisa está essencialmente formado, ligando quase todas as principais cidades desse País de 160 milhões de habitantes. Orientação política determinou que usos educacionais da rede deveriam ser encorajados e subsidiados. Assim, qualquer escola, pública ou privada, tem atualmente o direito de solicitar do nó mais próximo do sistema (geralmente uma universidade) um "user address" e acesso normal aos serviços completos das facilidades da Internet. Até agora, poucas escolas estão fazendo isso, em parte devido ao relativamente pequeno número de computadores, modems e linhas telefônicas em escolas públicas (um universo total, de acordo com as estatísticas do Ministério da Educação, de 200.000 escolas, 35 milhões de estudantes e mais de um milhão e meio de professores). Acredita-se que fatores econômicos causaram essa situação e que os próximos anos testemunharão uma melhora gradual, com o setor público, ajudado pelo setor privado, expandindo a introdução de computadores em escolas públicas, preparando professores "computer-literate" e reformulando o currículo para levar em conta a mudança na ênfase de memorização de informação para a de aprender a encontrar e avaliar informação.

A língua portuguesa, não obstante sua beleza intrínseca e largo uso na América Latina, Europa, África e Ásia (mais de 200 milhões de pessoas usam-na como meio principal de comunicação) não foi escolhida pelos produtores de software internacional e fornecedores de material instrucional como uma alternativa para produtos vendidos no mundo todo, e há, em geral, uma escassez de bens educacionais e serviços disponíveis na língua. Os proponentes do presente plano acreditam que a criação de uma "Biblioteca Virtual para o Estudante Brasileiro", oferecida livremente através da rede, servirá como um estímulo para escolas de todo 
- Brasil encontrarem meios de adquirir a plataforma necessária para o estudante/professor acessar a "Biblioteca" (computador, modem, linha-não-dedicada de telefone). Servindo de uma "cenoura na vara", uma influência motivadora, a existência de disponibilidade fácil ao depósito de informação obrigará o governo local de algumas comunidades a oferecer a plataforma a escolas públicas; em outras comunidades, o setor privado, pensando nas necessidades futuras de mão de obra; doará a plataforma necessária; ainda em outras situações, a associação de pais e mestres ou campanhas estudantis de levantamento de fundos porta a porta, encontrarão o dinheiro necessário para levar a escola a usar a nova geração de recursos educacionais.

Deve-se notar aqui que poucas escolas brasileiras têm qualquer tipo de biblioteca (menos ainda têm laboratórios de ciências), e o presente projeto representa, essencialmente, um gesto de "leap-frogging", saltando toda uma geração tecnológica (bibliotecas escolares baseadas em material impresso), e introduzindo estudantes e professores em uma geração tecnológica inteiramente nova (informação científica, tecnológica e cultural acessada remotamente sob demanda). Em vista da capacidade de armazenagem substancialmente grande dos equipamentos e software de base de dados atualmente disponíveis, será possível incluir tanto fontes materiais primarias como secundárias úteis na aprendizagem, independentemente de diferentes correntes de filosofias educacionais. De maneira alguma uma tentativa de substituir a escola ou o professor; a "Biblioteca Virtual" seria um lugar eletrônico a ser procurado para pesquisa estudantil, para consulta de obras não disponíveis no local em forma impressa. O fato de a Biblioteca do Congresso Americano e o Louvre da França estarem disponíveis na Internet não casou impacto na educação brasileira primeiro porque há atualmente poucos computadores em escolas e, segundo, porque nem os professores nem os alunos possuem a habilidade lingüística necessária para navegar com sucesso na rede. Acreditam, os proponentes, que o impacto do projeto na educação no Brasil, será significativo em todos os níveis, porque representa: (1) informação brasileira ou informação relacionada com o currículo educacional brasileiro, (2) na língua portuguesa, (3) disponível 24 horas por dia (há quatro zonas horárias no Brasil); muitos adultos terminam sua educação primária e secundária em cursos noturnos por todo o País, (4) sem constrangimentos financeiros--não haverá cobrança para o 
uso do sistema, e (5) uma fonte com credibilidade--a informação será selecionada e preparada por educadores da Universidade de São Paulo, o maior e mais respeitado centro de ensino do Brasil, acrescido pela colaboração de outras instituições que lidam com educação.

Se o projeto atingir seu gol desejado, seria possível, em um projeto seguinte, reproduzir o conteúdo em domínio público da "Biblioteca Virtual" em CD-ROM, tornando esse material digitalizado disponível off-line para escolas muito distantes dos nós universitários da Rede Nacional de Pesquisa ou incapazes de adquirir linhas telefônicas (no Brasil linhas telefônicas precisam ser compradas da concessionária telefônica, normalmente a um custo que varia de $R \$ 1.500,00$ a $R \$ 6.000,00$ ).

\section{Metodologia}

\section{Implementação}

O executor do projeto, uma vez aprovado, será a "Escola do Futuro", um laboratório interdisciplinar da Universidade de São Paulo, que desde 1989 vem investigando as novas tecnologias da comunicação e suas aplicações na educação. O laboratório é subordinado à Pro-Reitoria de Pesquisa da Universidade e tem mais de 100 pesquisadores nos níveis júnior e sênior fazendo investigações em várias linhas de pesquisa. Três dessas linhas tratam de ensino a distância usando a Internet, e uma considerável experiência foi adquirida nesses últimos cinco anos como resultado dos projetos descritos em outro lugar nessa proposta.

A implementação começaria com a formação de uma equipe de pesquisadores sênior e pesquisadores júnior, todos eles necessariamente familiarizados com educação a distância, tecnologias de comunicação interativa e Internet. Os seis primeiros meses do trabalho do grupo seriam devotados a (1) elaboração, em colaboração com nossos parceiros da University of British Columbia, de objetivos e estratégias educacionais específicos a serem alcançados através do Projeto, e as formas de avaliar o progresso educacional, custo em relação a benefícios, e resultados políticos e administrativos esperados; (2) determinar, de acordo com a Secretaria de Educação do Estado de São Paulo e a Associação das Escolas Particulares de São Paulo, o esquema básico da "Biblioteca Virtual", sua estrutura 
em relação a conteúdo (profundidade e extensão); indexação dos conteúdos, e formatação das atividades de ensino a serem construídas em torno dos trabalhos da "Biblioteca", e (3) instalação e teste do equipamento a ser empregado no Projeto.

Nos seis meses seguintes, o time prepararia a base de dados, digitando e escaneando textos e imagens de material existente no domínio público e visitando editoras possuidoras de direitos sobre o material ainda não no domínio público, solicitando sua colaboração no sentido de abrir mão dos direitos autorais para a "publicação" de seu material educacional na "Biblioteca Virtual".

O terceiro período de seis meses seria devotado a (4) manutenção do fluxo de informação entre a "Biblioteca" e seus usuários, discussões on-line, (5) "calibração" do sistema--correção de erros inevitáveis na entrada de dados, de indexação, de omissões, e (6) disseminação do sistema, através de apresentações e workshops com professores em encontros de educadores por todo o pais, apresentações no rádio e na televisão, e autoria de artigos descrevendo o sistema em jornais, publicações especializadas em educação e boletins de professores. Os últimos seis meses seriam concentrados em duas áreas importantes: (7) preenchimento das lacunas verificadas através do uso do sistema por professores e alunos e (8) preparação, junto com nossos colegas da University of British Columbia, da avaliação final do Projeto, na forma de relatório para a organização patrocinadora e como artigo a ser submetido a uma revista científica de nível internacional relatando o que foi aprendido como resultado do Projeto--o que funcionou e o que não funcionou, com recomendações para aqueles que estiverem pensando em seguir as trilhas dessa pesquisa.

Depois de 24 meses de investigação, é nossa intenção avaliar o Projeto e determinar se sua continuação deveria ser um projeto continuado de pesquisa da Escola do Futuro da Universidade de São Paulo, com um plano para novos estudos baseados no mesmo ou uma nova estrutura para a "Biblioteca" (por exemplo, expandindo seu conteúdo para incluir obras e materiais de nível universitário), ou se - Projeto deveria ser transferido para outra organização educacional para continuidade e expansão. 


\section{Alcance do Conteúdo da Base de Dados}

No presente momento, acredita-se que o conteúdo inicial da "Biblioteca Virtual" deverá estar intimamente ligado ao currículo oficial das escolas primária e secundária do País, a saber:

\section{Escola Primária}

Ciências

Matemática

História

Geografia

\section{Escola Secundária}

Biologia

Química

Física

Matemática

Orientação Vocacional

Orientação para o Trabalho

Educação Física
Português

Inglês

Educação Artística

Educação Física

Além das fontes primárias, obras literárias e textos históricos, deverão ser incluídos no banco de dados obras de referência, tabelas, gráficos, mapas (tanto históricos como contemporâneos) e outros guias úteis na busca de informação, consulta e avaliação.

Haveria desenvolvimento de entradas para os bancos de dados de acesso público já disponíveis para usuários profissionais da informação e contendo informação sobre o Brasil: INPE-Instituto Nacional de Pesquisas Espaciais (dados de sensoramento remoto dos últimos vinte anos); PRODASEN-banco de dados do Senado Federal (jurisprudência e legislação histórica e contemporânea); IBGE-Instituto Brasileiro de Geografia e Estatística (informação sobre o censo para todo o Brasil); Instituto Oswaldo Cruz (dados sobre questões referentes a saúde pública); BIREME-Biblioteca Regional de Medicina; DEDALUS--Catálogo on-line das Bibliotecas da Universidade de São Paulo. 
Os realizadores privados de CD-ROMs com informação sobre o Brasil, em número cada vez mais crescente, seriam convidados a submeter CD-ROMs apropriados para torná-los acessíveis através da rede sem custo para o usuário. Consultas preliminares com tais produtores tem indicado que eles estão dispostos a colaborar, vendo a "Biblioteca Virtual" como um mostruário, onde estudantes e professores poderiam testar os produtos CD-ROM, interessar-se por eles e então, eles esperam, comprá-los através de empresas comerciais regulares para uso nas escolas locais.

\section{Avaliação}

O Department of Distance Education and Technology in Continuing Studies da University of British Columbia, Vancouver, Canadá, concordou em colaborar com esse Projeto da "Biblioteca Virtual para Estudantes Brasileiros", aplicando um método de análise de custo-benefício de tecnologias de ensino a distância baseado no modelo ACTIONS. Isso oferecerá não somente dados adicionais de avaliação para os patrocinadores do Projeto, como também oferecerá aos administradores do Projeto informações básicas para modificações e mudanças no Projeto.

O modelo ACTIONS foi desenvolvido e testado durante muitos anos, e encontra-se descrito no seu todo em Bates (1995). Trata-se de uma sigla para um método de avaliação custo-benefício de várias aplicações tecnológicas de educação a distância:

Access - (acesso)

Costs - (custos)

Teaching and learning functions - (funções de ensino e aprendizagem)

Interaction and user-friendliness - (interação e amigablidade com o usuário)

Organization - (organização)

Novelty - (originalidade)

Speed - (velocidade)

Esses são critérios, com um sub-conjunto de questões, aplicáveis a aplicações tecnológicas em educação a distância, oferecendo uma ampla estrutura de avaliação. 
O modelo custo é baseado no custo por estudante/contato/hora para uma determinada tecnologia. No entanto, seu valor principal não é tanto a medida de custos unitariamente para uma determinada aplicação, mas a identificação das variáveis de custo principal e a estrutura de custos para uma determinada tecnologia (por exemplo, taxa de custos fixos e seus custos variáveis). Isso permite calcular custos para diferentes variáveis e condições de aplicação, possibilitando aos administradores acessar o impacto de aumento ou queda de volume de atividade ou o número de estudantes acessando materiais de estudo, ou mudando para tecnologias alternativas. Benefícios são medidos pelos critérios de:

- acesso por estudantes (que tipos de estudantes são capazes de usar essa tecnologia, e quantos a usam?)

- funções de ensino e aprendizado (que benefícios de ensino ou aprendizado são associados exclusivamente com essa tecnologia em qualquer aplicação específica?)

- interação e amigabilidade (que níveis de interação, tanto com máquinas como com pessoas, e habilidades essa tecnologia permite, e como essa aplicação utiliza essas características? Quão fácil ou difícil é o uso dessa tecnologia, tanto para os planejadores como para os estudantes?);

- originalidade (essa tecnologia é confiável e pronta para ser usada nesse contexto? Quão unusual ou avançada é essa aplicação em termos de tecnologia--hardware, software e/ou conectividade--nesse contexto cultural?);

- e por último, velocidade (com que rapidez materiais podem ser criados e modificados?)

Questões organizacionais oferecem uma estrutura para avaliar as condições institucionais ou contextuais com que o Projeto opera, e a análise de elementos organizacionais oferece um meio de identificar maneiras possíveis de aumentar a eficiência da aplicação. A avaliação é planejada para operar em dois níveis. O primeiro é prover a Universidade de São Paulo com uma estrutura de avaliação, e treinar pesquisadores locais na sua aplicação. Isso exigirá do Dr. A. W. Bates, Chefe do Departamento, fazer três viagens com duração de uma semana cada de Vancouver a São Paulo para treinar e supervisionar avaliadores locais. Um avaliador canadense também estará presente em São Paulo, durante partes do 
Projeto, para supervisionar diretamente o processo de avaliação, bem como manter as comunicações com o Canadá. Espera-se que comunicações através do computador e "compressed video-conferencing" sejam usadas para acelerar a transferência de informação entre os pesquisadores em Vancouver e São Paulo.

\section{Quem são os Proponentes}

A "Escola do Futuro" da Universidade de São Paulo é um laboratório de pesquisa interdisciplinar ligado à Pro-Reitoria de Pesquisa, investigando novas tecnologias de informação aplicadas à educação. Iniciou suas atividades em 1989 e hoje trabalha com mais de 100 pesquisadores, júniors e sêniors, vindos dos corpos docente e discente da Universidade (Escola de Engenharia, Instituto de Física, Faculdade de Filosofia, Letras e Ciências Humanas, Faculdade de Educação, Escola de Comunicações e Artes), além de seu próprio quadro de funcionários. Seus pesquisadores usam tecnologias avançadas para criar e avaliar materiais didáticos cuja finalidade é promover um novo paradigma em Educação, apropriado para uma sociedade de informação onde a tecnologia é usada para promover o estudo e a prática de valores humanos, o aprendizado de capacitações cognitivas da mais alta ordem e trabalho em colaboração da parte de estudantes e professores. Em 199597, a maioria dos pesquisadores é mantida por bolsas do CNPq. As linhas de pesquisa efetuadas no laboratório são: (I) Produção de Multimídia Interativa; (2) Ensino de Ciências através da Telemática; (3) Ensino de Humanidades através da Telemática; (4) BBS sobre Inovações em Educação; (5) Expressão Audiovisual; (6) Holografia e Produção de Materiais Gráficos; (7) Surveys; (8) Catálogo de Software Educacional Brasileiro; (9) Grupo de Estudo e Discussão; (10) Gatekeepers (Documentação). Bem equipado, com fibra ótica local de local e "wide-area networking" e seu nó próprio de Internet, a Escola do Futuro adquiriu, recentemente, equipamentos para produzir CD-ROMs em pequena quantidade e em dezembro de 1995, inaugurou, através de convênio com a UNISYS Brasil, duas "Salas de Aula do Futuro", ambientes do século 21 para desenvolvimento profissional de professores no uso de Internet, multimídia, holografia e outras inovações estratégicas. O Coordenador Científico do laboratório, Prof. Fredric M. Litto, (B.A UCLA, 1960; PhD., Indiana University, 1969; Livre Docência, USP, 1977), professor titular desde 197I, é atualmente Presidente da Associação Brasileira de Ensino a Distância. A Universidade de São Paulo, por sua vez, é a maior, mais antiga, e mais produtiva 
(em termos de trabalhos científicos publicados, teses defendidas) universidade brasileira. Fundada em 1934, conta hoje com 60.000 estudantes, 5.200 professores e 17.000 funcionários não-docentes.

A University of British Columbia é uma das três maiores universidades do Canadá, e está classificada entre as maiores instituições de pesquisa na América do Norte, com ganhadores do Prêmio Nobel entre seus professores. UBC vem oferecendo cursos a estudantes fora do campus universitário através de ensino a distância desde 1929, e hoje está se estabelecendo na vanguarda de ensino a distância baseada em sistemas de entrega tecnológica. Ela oferece, atualmente, cerca de 100 cursos de graduação a mais de 8.000 alunos por ano, mas está desenvolvendo rapidamente novos programas de educação a distância a nível de pós-graduação e certificado sem crédito. Até hoje, a maioria dos cursos é principalmente baseado em material impresso, com algum apoio dos meios audiovisuais como audio-cassetes, audio-conferência e video-cassetes ou programas de televisão. No momento está desenvolvendo novos cursos para serem administrados através da Internet, CDROM, e videoconferência. Dr. A.W. Bates é um dos pesquisadores mais antigos na área, tendo começado como membro fundador na British Open University em 1969, tornando-se mais tarde Professor de Educational Media Research, uma posição que manteve até 1989, quando saiu para se tornar Diretor Executivo, Strategic Planning, Research, and Information Technology na Open Learning Agency no Canadá. Ele ingressou na UBC em junho de 1995, como Diretor de Educação a Distância e Tecnologia. Seus grupos de pesquisa na British Open University e na Open Learning Agency já publicaram mais de 350 relatórios sobre tecnologia no ensino a distância. É autor de cinco livros sobre tecnologia e ensino a distância e já trabalhou como consultor em mais de 30 países sob o patrocínio do Banco Mundial, UNESCO, European Comission, Conselho Britânico, governos nacionais e estaduais, organizações de radiodifusão, e de muitas universidades convencionais e de ensino a distância. 


\section{BRIEF BIBLIOGRAPHY}

Bates, A.W. Technology, Open Learning and Distance Education. New York and London: Routledge, 1995.

"Television, Learning and Distance Education", Journal of Educational Television, Vol. 14, No. 3 (1988), 213-225.

Baath, J.A. "Distance Student's Learning--Empirical Findings and Theoretical Deliberations", Distance Education, Vol. 3, No. 1 [1982), 6-27.

Harasim, L. "Online Education: A New Domain for Collaborative Learning and Communication", in B. Feinstein and B. Kurshan, eds., Telecommunications in Education: Learners and the Global Village, International Society for Technology in Education, Jerusalem, Israel, 1989.

Knight, Peter T. "Education for All Through Electronic Distance Education", in Distance Learning and New Technologies in Education. Proceedings of the First International Conference on Distance Education in Russia, Moscow, 5-8 July, 1994. ICDED '94. Moscow, ICDED, 1994; pp. i-27-i-34.

Mason, R. and A. Kaye, eds. Mindweave: Communication, Computers, and Distance Education, London: Pergamon Press, 1989.

Morgan, A. "Qualitative Methodologies in Research in Distance Education", Distance Education, Vol. 5, No. 2 (1984), 252-67.

Nickerson, Raymond S. and Philip P. Zodhiates, eds. Technology in Education:

Looking Toward 2020. Hillsdale, N.J.: Lawrence Erlbaum Associates, 1988.

Romiszowski, A.J. andf J.A. Haas, "Computer-Mediated Communication for Instruction: Using E-Mail as a Seminar", Educational Technology, Vol. 29 No.10 (1989),7-14.

[Prof. Romiszowski will be a Visiting Researcher in the School of the Future of the University of São Paulo during the entire academic year of 1996.]

Schrum, L. "Information Age Innovations: A Case Study of Online Professional Development", Paper presented at the Annual Conference of the American Educational Research Association, San Francisco, California, 20-24 April 1992.

Sherwood-Roberts, P. and P. Vervest, "Technology Options for Multimedia in Distance Education", Report to the Commission of the European Communities, Task Force on Human Resources, Education, Training and Youth, Luxemburg, 1991. 


\section{Anexo 2}

\section{A ESCOLA DO FUTURO DA UNIVERSIDADE DE SÃO PAULO}

\section{Sua Missão}

A Escola do Futuro, núcleo de pesquisa da Universidade de São Paulo - USP, tem como principal atividade a investigação das novas tecnologias de comunicação aplicadas à educação.

Através do desenvolvimento de suas pesquisas e projetos, a Escola do Futuro deseja explorar e implementar propostas inovadoras e eficazes que, utilizando recursos como a Internet e a multimídia, contribuam decisivamente para a maximização das possibilidades do ensino e da aprendizagem. Para tanto, a atuação da Escola do Futuro tem como referência cinco princípios:

1. O compromisso com a pesquisa, a discussão e a avaliação de diferentes estratégias educacionais, privilegiando aquelas que incorporam, por um lado, os mais modernos conceitos sobre os processos de cognição humana e, por outro, as novas tecnologias de informação.

2. Desenvolver metodologias e materiais didáticos que conferiram um novo dinamismo ao ensino e à aprendizagem, presencialmente ou à distância.

3. Preparar novas gerações de educadores que vejam na interface entre educação e comunicação um campo fértil para sua criatividade, discernimento e constante aperfeiçoamento.

4. Promover a aceleração do intercâmbio de idéias e experiências entre educadores e instituições acadêmicas através da realização de cursos, seminários, oficinas e outros eventos. Pretende-se, assim, conciliar a pesquisa universitária com a prática da sala de aula.

5. Servir como um modelo de parceria entre a universidade, a sociedade e diferentes agências e esferas de governo, todos comprometidos com o aperfeiçoamento da Educação no Brasil. Este compromisso fundamenta-se em um novo horizonte de justiça social e de construção e exercício da cidadania em nosso país. 


\section{Conselho Deliberativo}

$\begin{array}{ll}\text { Gita Guinsburg } & \text { peretz@netpoint.com.br } \\ \text { José Manoel Moran Costas } & \text { immoran@usp.br } \\ \text { Leland Emerson McCleary } & \text { mccleary@usp.br } \\ \text { Osvaldo Sangiorgi } & \text { osangior@usp.br } \\ \text { Romero Tori } & \text { rometori@usp.br }\end{array}$

\section{Coordenador Científico - Prof. Dr. Fredric Michael Litto}

Nascido na Cidade de Nova lorque em 1939, Bacharel em Rádio e Televisão pela UCLA (Universidade de California, Los Angeles) em 1960, Ph.D. em Comunicações pela Universidade de Indiana em 1969, e Livre Docente pela Universidade de São Paulo em 1977.

Lecionou nas Universidades de Indiana (1960-1964), Bowdoin (1964-1965), e Kansas (1965-1971).

Desde 1971 é Professor Titular da Escola de Comunicações e Artes da USP, atuando no Departamento de Cinema, Rádio e Televisão.

Nos últimos 15 anos tem dedicado seus esforços de ensino e pesquisa ao campo de "Comunicação Mediada por Computadores", e já orientou mais de 30 teses de mestrado e doutorado.

Foi Consultor da CAPES (1974-1980), do CNPq (1980-1985), e da FAPESP (1990atual). Trabalhou em Rádio Educativa em Los Angeles (Pacifica Foundation KPFKFM e UCLA Rádio) 1958-1960, e em Televisão Educativa (UCLA TV) 1959-1960.

Foi Consultor do Projeto Saci do Instituto Nacional de Pesquisas Espaciais (São José dos Campos) em 1972, Consultor da Fundação Padre Anchieta, São Paulo, 1977-78, e membro do Comité Assessor de Informática em Educação do Ministério da Educação (1985-1992). 
Em 1987-1988 foi "Visiting Scholar" (Pesquisador Visitante) no Departamento de Comunicações da Universidade de Stanford.

Desde 1989 é Fundador-Coordenador Científico da Escola do Futuro, laboratório interdisciplinar de pesquisa da Universidade de São Paulo que investiga as aplicações educativas das novas tecnologias comunicação www.futuro.usp.br.

Em 1995 foi eleito Presidente da Associação Brasileira de Educação a Distância (ABED), e re-eleito em 1999 para um segundo mandato www.abed.org.br

Desde 1999 ele é Membro do Conselho Editorial da nova revista científica publicada pela editora Routledge da Inglaterra, Education, Communication \& Information, junto a Howard Gardner da Universidade Harvard e Mitchel Resnik do Media Lab do MIT. Participou em anos recentes de reuniões internacionais de educação a distância em Moscow (1994), Saratoga Springs (1995), Lisboa (1996), Toronto (1997), University Park, Pennsylvania (1998), Vancouver (1998), Tel Aviv (1998), Viena (1999), Caracas (1999), Montreal (1999) e Berlin (1999), além de outros conclaves relacionados às novas tecnologias de comunicação e a educação, em Santa Clara, California (anualmente desde 1989), Londres (1994), Barranquilla, Colombia (1995), Cartagena, Colombia (1996), e Aguascalientes, Mexico(1999).

\section{Artigos Publicados}

Todos encontrados no site da Escola do Futuro - www.futuro.usp.br

- Educação inflexível e tutelada (agosto de 2001)

- Existem bons argumentos para justificar a presença da matemática no currículo geral? (junho de 2001)

- Excluídos, mais excluídos e nós (março de 2001)

- Indicadores de uma escola moderna...um "checklist" (fevereiro de 2001)

- Telecentros Comunitários -- Uma Resposta à "Exclusão Digital" (dezembro de 2000)

- Aprendizagem Profunda e Aprendizagem de Superfície (outubro de 2000)

- De Onde Virão os Cientistas e Tecnólogos Brasileiros do Futuro? (agosto de 2000) 
- Fazer faculdade, não fazer faculdade, ou fazer uma faculdade diferente ( julho de 2000)

- A Educação de Militares na Sociedade Contemporânea (março 2000)

- Fantasias no Ibirapuera, o Trabalho Colaborativo e o Futuro da Sociedade Brasileira (janeiro 2000)

- Salário do Professor em Função do Desempenho do seu Aluno (outubro 1999)

- O Novo Ambiente Para Aprendizagem (março 1999)

- Educação Brasileira se Globaliza (janeiro 1999)

- País Sem Coesão Social (dezembro 1998)

- "What Was Cool" no Canadá - TeleLearning '98 (dezembro 1998)

- "What's Cool" nos Estados Unidos? (novembro 1998)

- Aprender a Pensar Não Pode Ser um Sub-Produto da Educação (outubro 1998)

- Se Fosse Vivo, Albert Einstein agora Poderia Ser Professor em Nova York (outubro 1998)

- Reflexão, Pragmatismo e a Tecnologia na Educação (setembro 1998)

- Universidade, do Sagrado ao Profano (setembro 1998)

- Resistência à Modernização da Educação: Reflexão X Pragmatismo (setembro 1998)

- A Cúpula das Américas em Santiago: Educação Novamente Marcando Passo (agosto 1998)

- Não Há Censura Que Segure a Internet (maio 1998)

- Computerfobia: De Quem É a Culpa? (abril 1998)

- A "Geração de Rede" Está Chegando ao Mercado de Trabalho... e Mudando as Organizações (março 1998)

- Informática, Religião e a Educação (fevereiro 1998)

- Um Modelo para Prioridades Educacionais numa Sociedade de Informação (novembro 1997)

- O Ensino de Ciência e a Formação da Mente do Aluno (novembro 1997)

- Novas Formas de Pensar (outubro 1997)

- Eu Te Mostro o Meu Se Você Me Mostrar o Seu (setembro 1997)

- "Paiê, eu Preciso de Cultura!" (setembro 1997) 


\section{Os Pesquisadores da Escola do Futuro}

São pessoas que têm a necessidade de fazer parte de algo inovador e criativo. Acreditam na Missão da Escola do Futuro e estão dispostos a contribuir com o máximo de seus esforços para que ela se realize. São profissionais comprometidos com o crescimento da Instituição e que trabalham de forma colaborativa. Compreendem a importância do aprendizado em ambientes dinâmicos e interativos. Consideram o professor como mentor e facilitador do processo de aprendizagem e a tecnologia como ferramenta indispensável à Educação.

\section{Equipe}

Akira Shiguemori

Alda Ribeiro Martins

Américo Sommerman

Ana Maria Pereira dos Santos

Ana Paula Leite de Camargo

Beatriz Ansarah Rizek

Brasilina Passarelli

Carlos Seabra

Clarice Meyer Cabral

Cristiane Rodrigues C. Tavolaro

Dirlene Patrocínio de Oliveira

Drica Guzzi

Fathia Nordon de Gouveia

Isabel Pereira dos Santos

Leland Emerson McCleary

Lia Caprara

Luciana Maria Allan Salgado

Luiz Caldeira Brant de T. Neto

Maria de Mello

Marisa de Almeida Cavalcante

Nelio Bizzo

Paulo Puterman

Priscilla Marques Ballarin

Ricardo Antunes

Ruth Ribas Itacarambi

Silvia Fichmann

Simone Silva Freitas

Thais Waisman 


\section{Projetos}

\section{A Evolução Transdisciplinar na Educação}

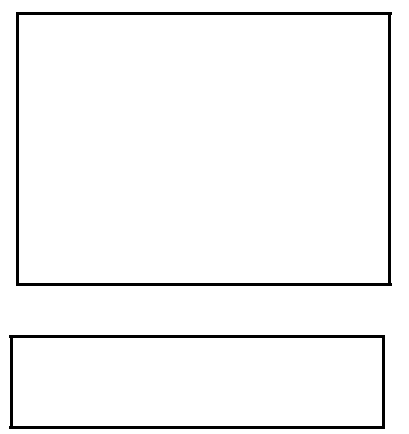

A Transdisciplinaridade, em uma rápida explanação, é um modo de conhecimento. Etimologicamente, o sufixo trans significa aquilo que está ao mesmo tempo entre as disciplinas e além de toda disciplina.

Durante os dois anos previstos para sua duração, o projeto da Evolução Transdisciplinar na Educação propõese, entre outros objetivos, a realizar uma reflexão sobre a epistemologia transdisciplinar e a formar presencial e virtualmente cerca de 40 educadores, cada um dos quais será responsável pela criação e implementação de projetos-piloto que utilizem metodologia e conteúdo transdisciplinares. http://www.cetrans.futuro.usp.br/

\section{Projeto Comunidade Virtual Telemar}

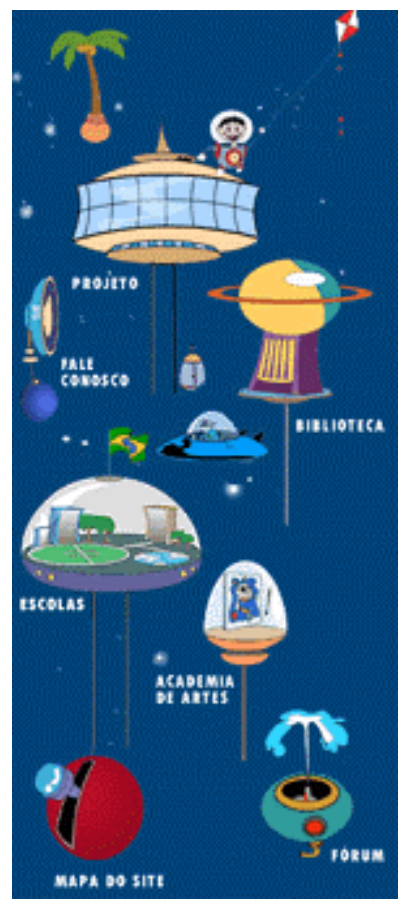

Resultado da parceria entre a Telemar e a Escola do Futuro da USP, propicia a implementação de uma rede de comunicação entre escolas públicas de ensino fundamental, localizadas em 16 Estados brasileiros, com conteúdos pedagógicos, possibilitando acesso aos alunos e aos professores como ferramenta didática.

Cada uma das escolas desenvolverá projetos comunitários, visando beneficiar a população em torno das escolas indicadas. No site do Projeto você encontrará as escolas envolvidas e o desenvolvimento das atividades didático - pedagógicas e poderá acompanhar o estágio de implementação dos projetos comunitários. http://www.educacao.telemar.com.br/ 


\section{Projeto Edsoft}

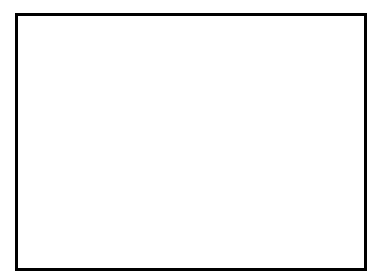

O Projeto Edsoft tem como objetivo a criação de uma base de dados de softwares educacionais em língua portuguesa.

Assim, a comunidade de educadores, estudantes e usuários destes softwares têm acesso à informações atualizadas sobre tais publicações.

http://www.edsoft.futuro.usp.br/

\section{Projeto Ensino de Ciências \& Tecnologia}
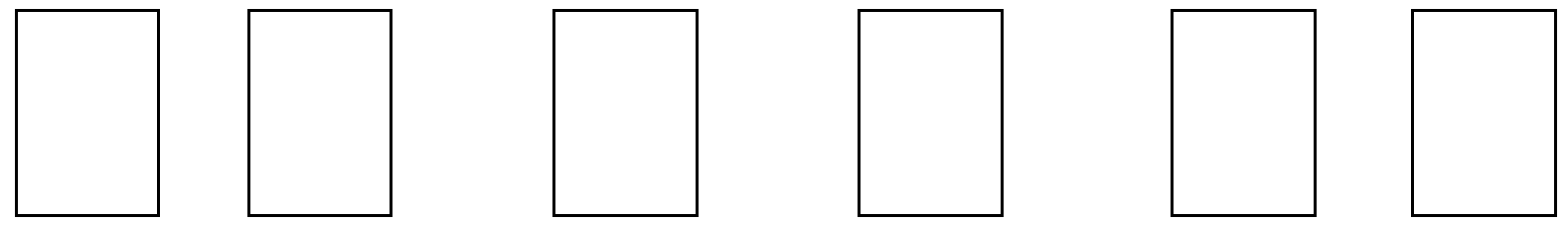

Desenvolvendo projetos inovadores situados nos mais variados contextos (Botânica, Zoologia, Termodinâmica e Termologia, Gestão Ambiental, Epidemiologia, Saúde, História da Ciência, Astronomia, etc.) junto a alunos de 7 a 17 anos de idade, em escolas públicas e particulares, o Grupo de Ciências \& Tecnologia tem como meta aliar tecnologias inovadoras de processamento de dados com metodologias de ensino avançadas e motivadoras. http://darwin.futuro.usp.br/

\section{Projeto ONU Virtual}

O ONU Virtual é o primeiro projeto temático do Mutirão Digital uma iniciativa da Fundação de Rotarianos de São Paulo e da Escola do Futuro/USP - para beneficiar as escolas públicas brasileiras na construção de Comunidades Virtuais de Aprendizagem. Através do ONU Virtual as escolas públicas de todo o país podem pesquisar, trocar mensagens, criar e publicar trabalhos sobre os temas geradores: Educação para a Paz, Desenvolvimento Sócio-Econômico e Direitos Humanos. http://www.onuvirtual.futuro.usp.br/ 


\section{Anexo 3}

\section{BIBLIOTECAS BRASILEIRAS NA INTERNET}

\begin{tabular}{|c|c|}
\hline $\begin{array}{l}\text { Audioteca Sal e Luz. } \\
\text { http://www.audioteca.com.br } \\
\text { Available from Internet: [15.01.2002] }\end{array}$ & $\begin{array}{l}\text { A Audioteca Sal e Luz é uma instituição de } \\
\text { utilidade pública, sem fins lucrativos, que presta } \\
\text { serviço para cegos e portadores de deficiência } \\
\text { visual. Produzindo e emprestando livros gravados } \\
\text { em fitas K-7 (livros falados) em todo território } \\
\text { nacional. O site disponibiliza: informações gerais; } \\
\text { ficha de inscrição e catálogo. }\end{array}$ \\
\hline $\begin{array}{l}\text { Biblioteca Ana Maria Poppovic - BAMP } \\
\text { http://www.fcc.org.br/biblioteca/principal.html } \\
\text { Available from Internet: [15.01.2002] }\end{array}$ & $\begin{array}{l}\text { O acervo desta Biblioteca, ligada à Fundação } \\
\text { Carlos Chagas, é especializado em educação, } \\
\text { mulher, criança pequena, material pedagógico, } \\
\text { entre outros. A página informa sobre o horário de } \\
\text { funcionamento, os produtos e serviços. A consulta } \\
\text { on-line é feita tanto no acervo da Biblioteca quanto } \\
\text { na base de dados DBFCC - Descrição Bibliográfica } \\
\text { Fundação Carlos Chagas. }\end{array}$ \\
\hline $\begin{array}{l}\text { Biblioteca da Faculdade de Educação da } \\
\text { Universidade Federal de Minas Gerais } \\
\text { (UFMG). } \\
\text { http://www.fae.ufmg.br } \\
\text { Available from Internet: [15.01.2002] }\end{array}$ & $\begin{array}{l}\text { A Biblioteca da Faculdade de Educação é parte } \\
\text { integrante do Sistema de Bibliotecas da UFMG, na } \\
\text { qualidade de Biblioteca Setorial, responsável pelo } \\
\text { acervo da Universidade na área Ciências da } \\
\text { Educação. A página disponibiliza acesso à base de } \\
\text { dados. }\end{array}$ \\
\hline $\begin{array}{l}\text { Biblioteca do Centro Brasileiro de Filosofia } \\
\text { para Crianças. } \\
\text { http://www.cbfc.com.br/biblioteca/biblio.htm } \\
\text { Available from Internet: [15.01.2002] }\end{array}$ & $\begin{array}{l}\text { Disponibiliza a Coleção Pensar, desenvolvida pelo } \\
\text { Centro Brasileiro de Filosofia para Crianças. } \\
\text { Reúne artigos de filósofos e teóricos da Educação, } \\
\text { dirigidos a professores e educadores. Os textos } \\
\text { apresentados apontam para uma nova perspectiva } \\
\text { de enfoque educacional, voltada para o } \\
\text { desenvolvimento do pensar. }\end{array}$ \\
\hline $\begin{array}{l}\text { Biblioteca Setorial do Centro de Ciências } \\
\text { da Educação - BSCED } \\
\text { http://www.bu.ufsc.br/ced/bsced.html } \\
\text { Available from Internet: [15.01.2002] }\end{array}$ & $\begin{array}{l}\text { Biblioteca Setorial do Centro de Ciências da } \\
\text { Educação da Universidade Federal de Santa } \\
\text { Catarina. Acervo, de livre acesso, composto por } \\
\text { livros, periódicos nacionais e internacionais, } \\
\text { folhetos, relatórios, teses, obras de referência, } \\
\text { anais, fitas de vídeo, obras em CD-ROM e bases } \\
\text { de dados, abrangendo as áreas de Educação, } \\
\text { Biblioteconomia e Ciência da Informação. } \\
\text { Disponibiliza links para o acervo, empréstimo, }\end{array}$ \\
\hline
\end{tabular}




\begin{tabular}{|c|c|}
\hline & \begin{tabular}{|llll}
$\begin{array}{l}\text { aquisições e } \\
\text { bibliográficas. }\end{array}$ & & & \\
\end{tabular} \\
\hline $\begin{array}{l}\text { Biblioteca Virtual Anísio Teixeira. } \\
\text { http://www.prossiga.br/anisioteixeira/ } \\
\text { Available from Internet: [15.01.2002] }\end{array}$ & $\begin{array}{l}\text { A Biblioteca Virtual Anísio Teixeira é uma das } \\
\text { Bibliotecas de Pesquisadores desenvolvidas pelo } \\
\text { Prossiga/CNPq. Disponibiliza a produção científica } \\
\text { e técnico-administrativa do educador. }\end{array}$ \\
\hline $\begin{array}{l}\text { Biblioteca Virtual de Educação a Distância. } \\
\text { http://www.prossiga.br/edistancia/ } \\
\text { Available from Internet: [15.01.2002] }\end{array}$ & $\begin{array}{l}\text { Site desenvolvido pelo Núcleo de Pesquisa } \\
\text { Educação e Comunicação da Faculdade de } \\
\text { educação da Universidade Federal da Bahia - } \\
\text { UFBA em parceria com o Prossiga/CNPq. } \\
\text { Apresenta referências de sites, organizados por } \\
\text { sub-temas, sobre Educação a Distância e } \\
\text { disponibiliza ambientes interativos para envio de } \\
\text { artigos, resenhas e comentários relacionados à } \\
\text { temática. }\end{array}$ \\
\hline $\begin{array}{l}\text { Biblioteca Virtual de Educação a Distância } \\
\text { do Campus Global. Pontifícia Universidade } \\
\text { Católica do Rio Grande do Sul (PUC/RS). } \\
\text { http://www.cglobal.pucrs.br/fs2cglobal.htm } \\
\text { Available from Internet: [15.01.2002] }\end{array}$ & $\begin{array}{l}\text { Biblioteca da Pontifícia Universidade Católica do } \\
\text { Rio Grande do Sul - PUC/RS. Apresenta } \\
\text { referências de sites relacionados à Educação a } \\
\text { Distância e temas correlatos. Os sites são } \\
\text { divididos em categorias, tais como, Conceitos de } \\
\text { EAD, Projetos, Universidades Virtuais, Cursos a } \\
\text { Distância, Listas de Discussão, Livros, Artigos e } \\
\text { Eventos. }\end{array}$ \\
\hline $\begin{array}{l}\text { Biblioteca Virtual de Literatura. } \\
\text { http://www.biblio.com.br } \\
\text { Available from Internet: [15.01.2002] }\end{array}$ & $\begin{array}{l}\text { A página possui cerca de } 300 \text { obras - romances, } \\
\text { poesias, contos, teatro, crônicas, novelas, textos } \\
\text { completos de autores brasileiros e portugueses - } \\
\text { disponíveis para leitura na rede. O site } \\
\text { disponibiliza: autores e suas obras, biografias, } \\
\text { novidades, leituras obrigatórias para o vestibular e } \\
\text { dicionário. }\end{array}$ \\
\hline $\begin{array}{l}\text { Biblioteca Virtual do Estudante Brasileiro. } \\
\text { http://www.bibvirt.futuro.usp.br/ } \\
\text { Available from Internet: [15.01.2002] }\end{array}$ & $\begin{array}{l}\text { A Biblioteca Virtual do Estudante Brasileiro é um } \\
\text { projeto da Escola do Futuro, núcleo de pesquisa } \\
\text { da Universidade de São Paulo. Oferece acesso } \\
\text { gratuito ao acervo de literatura, materiais didáticos, } \\
\text { imagens, sons e atividades relacionados ao ensino } \\
\text { fundamental, ensino médio e cursos técnicos do } \\
\text { Brasil }\end{array}$ \\
\hline $\begin{array}{l}\text { Biblioteca Virtual do IBICT. } \\
\text { http://www.ibict.br } \\
\text { Available from Internet: [15.01.2002] }\end{array}$ & $\begin{array}{l}\text { Possui uma coleção especializada em Ciência da } \\
\text { Informação e Política Científica e Tecnológica, } \\
\text { formada por livros, periódicos, teses, relatórios, }\end{array}$ \\
\hline
\end{tabular}




\begin{tabular}{|c|c|}
\hline & $\begin{array}{l}\text { vídeos, memória técnica, anais, entre outros } \\
\text { documentos. }\end{array}$ \\
\hline $\begin{array}{l}\text { Centro de Informações Multieducação. } \\
\text { http://www.rio.ri.gov.br/multirio/cime/index.html } \\
\text { Available from Internet: [15.01.2002] }\end{array}$ & $\begin{array}{l}\text { Página desenvolvida pela Prefeitura da Cidade do } \\
\text { Rio de Janeiro e a Empresa Municipal de } \\
\text { Multimeios Ltda - MULTIRIO. Disponibiliza } \\
\text { informações na área educacional, oferecendo } 4 \\
\text { formas de navegação: por Grandes Temas, } \\
\text { através dos Programas Multirio, por Palavras- } \\
\text { Chave ou Formulando Perguntas. }\end{array}$ \\
\hline $\begin{array}{l}\text { Coleção Línguas Indígenas do Brasil. } \\
\text { http://www.unicamp.br/iel/cedae/cedae- } \\
\underline{\text { flib.html }} \\
\text { Available from Internet: [15.01.2002] }\end{array}$ & $\begin{array}{l}\text { Coleção do Centro de Documentação Cultural } \\
\text { Alexandre Eulálio (CEDAE), vinculado ao Instituto } \\
\text { de Estudos da Linguagem (IEL) da Universidade } \\
\text { Estadual de Campinas - UNICAMP-SP-Brasil. A } \\
\text { coleção compreende registros de } 68 \text { línguas } \\
\text { indígenas indexadas alfabeticamente. }\end{array}$ \\
\hline $\begin{array}{l}\text { Grupo de Trabalho - Bibliotecas Virtuais. } \\
\text { http://www.cg.org.br/gt/gtbv/bibliotecas.htm } \\
\text { Available from Internet: [15.01.2002] }\end{array}$ & $\begin{array}{l}\text { O site do Comitê Gestor da Internet no Brasil } \\
\text { apresenta as Bibliotecas Virtuais classificadas por } \\
\text { Categoria, Estado e Projetos de bibliotecas virtuais } \\
\text { no mundo. }\end{array}$ \\
\hline $\begin{array}{l}\text { Programa de Estudos e Documentação } \\
\text { Educação e Sociedade - PROEDES. } \\
\text { http://www.cfch.ufri.br/proedes/proedes.html } \\
\text { Available from Internet: [15.01.2002] }\end{array}$ & $\begin{array}{l}\text { Constitui centro de documentação sobre educação } \\
\text { brasileira. Realiza estudos e pesquisas referentes } \\
\text { a temas na área de Educação e sobre instituições } \\
\text { educacionais e científicas. Constitui-se em um } \\
\text { centro de documentação em educação brasileira. }\end{array}$ \\
\hline $\begin{array}{l}\text { Prossiga Brasil. } \\
\text { http://www.prossiga.br/prossigabrasil/ } \\
\text { Available from Internet: [15.01.2002] }\end{array}$ & $\begin{array}{l}\text { Este site é um portal de informação brasileira em } \\
\text { C\&T. Tem por base selecionar e disponibilizar } \\
\text { informações relativas à educação no que diz } \\
\text { respeito a Pesquisadores; Docentes; Cursos de } \\
\text { Especialização; Cursos de Doutorado; Cursos de } \\
\text { Mestrado; Cursos de Graduação; Bibliotecas; } \\
\text { Centros de Informação; Centros de Documentação } \\
\text { e Atividades de Pesquisa. As informações têm } \\
\text { como origem, Institutos de Pesquisa e Tecnologia } \\
\text { e Universidades. }\end{array}$ \\
\hline $\begin{array}{l}\text { Repositório de Informações Educacionais. } \\
\text { http://lite.fae.unicamp.br/repeduc/ } \\
\text { Available from Internet: [15.01.2002] }\end{array}$ & $\begin{array}{l}\text { Iniciado pela RNP - Rede Nacional de Pesquisa - } \\
\text { tem como finalidade a divulgação de informações } \\
\text { da área educacional. Sua atualização é de } \\
\text { responsabilidade do Laboratório Interdisciplinar de } \\
\text { Tecnologias Educacionais (LITE). O site possui } \\
\text { temas gerais e específicos da área, além de }\end{array}$ \\
\hline
\end{tabular}




\begin{tabular}{|c|c|}
\hline & odutos de pesquisa, periódicos e \\
\hline $\begin{array}{l}\text { Repositório de Informática na Educação na } \\
\text { Universidade Federal do Rio Grande do } \\
\text { Sul-RS-Brasil. } \\
\text { http://penta.ufrgs.br/edu/home edu.htm } \\
\text { Available from Internet: [15.01.2002] }\end{array}$ & $\begin{array}{l}\text { Página da Universidade Federal do rio Grande do } \\
\text { Sul - UFRGS. Apresenta uma lista links vários } \\
\text { textos, sites, ementa de disciplinas de graduação, } \\
\text { eventos e outras fontes de informação sobre o uso } \\
\text { da informática na Educação. }\end{array}$ \\
\hline $\begin{array}{l}\text { SciELO - Scientific Electronic Library } \\
\text { Online. } \\
\text { http://www.scielo.br/ } \\
\text { Available from Internet: [15.01.2002] }\end{array}$ & $\begin{array}{l}\text { O site da SciELO é parte do Projeto } \\
\text { FAPESP/BIREME e um dos produtos da aplicação } \\
\text { da metodologia para preparação de publicações } \\
\text { eletrônicas em desenvolvimento. SciELO é uma } \\
\text { biblioteca virtual que abrange uma coleção } \\
\text { selecionada de periódicos científicos brasileiros. O } \\
\text { acesso aos títulos dos periódicos e aos artigos, } \\
\text { inclusive na área educacional, pode ser feito } \\
\text { através de índices e de formulários de busca. }\end{array}$ \\
\hline $\begin{array}{l}\text { Sistema Brasileiro de Documentação e } \\
\text { Informação Desportiva - SIBRADID. } \\
\text { http://www.sibradid.eef.ufmg.br/geral.html } \\
\text { Available from Internet: [15.01.2002] }\end{array}$ & $\begin{array}{l}\text { Centro de Informação em Ciências do Esporte, } \\
\text { Educação Física, Fisioterapia, Terapia } \\
\text { Ocupacional, Lazer, Recreação e afins da Escola } \\
\text { de Educação Física da Universidade Federal de } \\
\text { Minas Gerais. Fornece links para parceiros, base } \\
\text { de dados bibliográficas, periódicos, lista de } \\
\text { corporações e federações desportivas, eventos } \\
\text { entre outros. }\end{array}$ \\
\hline $\begin{array}{l}\text { Universidade de São Paulo - Biblioteca da } \\
\text { Faculdade de Educação. } \\
\text { http://www.fe.usp.br/biblioteca/ } \\
\text { Available from Internet: [15.01.2002] }\end{array}$ & $\begin{array}{l}\text { Biblioteca especializada em Educação, Psicologia } \\
\text { e Filosofia. A consulta ao acervo Educação é } \\
\text { possível através do Catálogo On-line Local da } \\
\text { Faculdade de Educação da Universidade de São } \\
\text { Paulo. }\end{array}$ \\
\hline $\begin{array}{l}\text { Universidade Federal do Rio Grande do Sul } \\
\text { - Biblioteca de Educação. } \\
\text { http://www.ufrgs.br } \\
\text { Available from Internet: [15.01.2002] }\end{array}$ & $\begin{array}{l}\text { Biblioteca de Educação da Faculdade de } \\
\text { Educação da Universidade Federal do Rio Grande } \\
\text { do Sul - UFRGS. Apresenta o endereço, horário de } \\
\text { funcionamento, acervo (tipo de material, assuntos } \\
\text { predominantes e principais obras de referência) e } \\
\text { serviços oferecidos. }\end{array}$ \\
\hline $\begin{array}{l}\text { Universidade São Francisco - CDAPH - } \\
\text { Centro de Documentação e Apoio à } \\
\text { Pesquisa em História da Educação. } \\
\text { http://www.usf.br/CDAPH/ } \\
\text { Available from Internet: [15.01.2002] }\end{array}$ & $\begin{array}{l}\text { O CDAPH da Universidade São Francisco - UFS, } \\
\text { São Paulo, coleta e organiza acervos documentais } \\
\text { de origens e características diversas. Busca } \\
\text { intercâmbio com entidades congêneres, promove } \\
\text { atividades acadêmico-científicas, realiza e divulga }\end{array}$ \\
\hline
\end{tabular}




\begin{tabular}{|c|c|}
\hline & $\begin{array}{l}\text { pesquisas. Disponibiliza seu acervo, publicações, } \\
\text { projetos, eventos e núcleos. }\end{array}$ \\
\hline $\begin{array}{l}\text { Fundação Biblioteca Nacional } \\
\frac{\text { www.bn.br }}{\text { Available from Internet: }} \text { [15.01.2002] }\end{array}$ & $\begin{array}{l}\text { Site da Fundação Biblioteca Nacional. Acesso ao } \\
\text { acervo digital da biblioteca com obras de } \\
\text { referências, romances, contos, poesia, teatro e } \\
\text { crônicas brasileiras, além de links de bibliotecas } \\
\text { nacionais e estrangeiras, universidades, } \\
\text { instituições, centros de pesquisa, jornais, museus } \\
\text { e o Diário Oficial. }\end{array}$ \\
\hline $\begin{array}{l}\text { Portal Capes } \\
\text { www.periodicos.capes.gov.br/ } \\
\text { Available from Internet: [15.01.2002] }\end{array}$ & $\begin{array}{l}\text { O Portal é uma ferramenta para pesquisas } \\
\text { bibliográficas, através de bases de dados } \\
\text { referenciais. Permite o acesso a um conjunto } \\
\text { expressivo de periódicos estrangeiros, de capa a } \\
\text { capa. }\end{array}$ \\
\hline $\begin{array}{l}\text { Biblioteca Virtual } \\
\text { www.bibliotecavirtual.com.br } \\
\text { Available from Internet: [15.01.2002] }\end{array}$ & $\begin{array}{l}\text { Serviço gratuito, onde a maior parte dos textos, } \\
\text { trabalhos e artigos são enviados pelos próprios } \\
\text { usuários do site ou, em alguns casos, foram } \\
\text { retirados sob autorização dos seus autores, de } \\
\text { sites públicos. }\end{array}$ \\
\hline $\begin{array}{l}\text { Saber - portal do conhecimento } \\
\text { www.saber.usp.br } \\
\text { Available from Internet: [15.01.2002] }\end{array}$ & $\begin{array}{l}\text { Biblioteca digital de teses e dissertação da USP, o } \\
\text { "Saber - Portal do Conhecimento" }\end{array}$ \\
\hline
\end{tabular}




\section{Anexo 4}

\section{PESQUISA COLOCADA NO SITE DA BIBLIOTECA VIRTUAL DO ESTUDANTE BRASILEIRO.}

Preparamos um breve questionário a fim de conhecer melhor os visitantes da Biblioteca Virtual do Estudante Brasileiro. Com os resultados desta pesquisa que serão utilizados pela mestranda Luciana Salgado em um projeto de avaliação da Bibvirt - poderemos atendê-los bem melhor.

Este questionário possui 37 perguntas, e levará cerca de 5 a 10 minutos para ser respondido. Agradecemos o tempo e a atenção dispensados em nosso auxílio.

1. Idade

$\square$ abaixo de 9 anos

$\square$ de 10 a 13 anos

$\square$ de 14 a 17 anos

$\square$ de 18 a 21 anos

$\square$ de 22 a 25 anos

$\square$ de 26 a 29 anos

$\square$ de 30 a 39 anos

$\square$ de 40 a 55 anos

$\square$ mais de 55 anos

2. Sexo

$\square$ Masculino

$\square$ Feminino

3. Em que cidade e estado você mora?

Cidade:

Estado:

4. Qual é a sua principal ocupação?

Bibliotecário

Estudante de $1^{\circ} \mathrm{Grau}$

Estudante de $2^{\circ} \mathrm{Grau}$

$\square$ Estudante Universitário

Pedagogo

$\square$ Professor $1^{\circ} \mathrm{Grau}$

$\square$ Professor $2^{\circ} \mathrm{Grau}$

Professor Universitário

Webmaster

Outros:

5. Qual é a sua renda mensal familiar (em $\mathrm{R} \$)$ ?
$\square$ até 300
de 301 a 600
de 601 a 1200
$\square$ de 1201 a 3000 
$\square$ de 3001 a 6000

$\square$ de 6001 a 10.000

$\square$ de 10.001 a 20.000

mais de 20.001

6. Se você é estudante ou professor, sua escola é: (se você não é estudante ou professor, não responda).

Pública

$\square$ Particular

7. Se você é estudante ou professor, na sua escola existem computadores ligados à Internet para uso dos alunos? (se você não é estudante ou professor não responda)

$\square \operatorname{Sim}$

Não

8. Se você é estudante, na sua escola os professores estimulam o uso da Internet para pesquisa? (se você não estudante não responda).

$\square$ Sim, todos

$\square$ Alguns

Nenhum

9. Como ele faz essa orientação?

Pede a pesquisa na Internet, mas não dá nenhuma referência.

$\square$ Pede a pesquisa na Internet, indicando alguns sites interessantes

relacionados ao tema.

$\square$ Vivencia o processo de busca de informação com você, fornecendo o endereço de alguns sites interessantes e estimulando a procura de outros relacionados ao tema.

10. De onde você mais acessa a Internet?

$\square$ em casa

na casa de amigos/parentes

$\square$ na escola/universidade

no trabalho

$\square$ na biblioteca

outros

11. Qual navegador você utiliza com mais freqüência? explorer até $3 . x$ explorer até $4 . x$ explorer até $5 . x$ netscape até $3 . x$ netscape até $4 . x$

$\square$ outro

12. Normalmente, como é a velocidade de acesso ao site da Bibvirt? Muito rápida

$\square$ Rápida 
$\square$ Normal

$\square$ Lenta

$\square$ Muito lenta

15. Para que você mais usa a Bibvirt?

$\begin{array}{ll}\square & \text { Estudo/p } \\ \square & \text { Lazer } \\ \square & \text { Trabalho } \\ \square & \text { Outros }\end{array}$

Se você escolheu outros, por favor descreva para que usa:

16. Você consegue localizar facilmente as informações no acervo da Bibvirt?

$\square$ Sempre

$\square$ Quase sempre

Às vezes

$\square$ Raramente

Nunca

17. Que informação você está procurando na Bibvirt e para que você precisa dela?

18. Você a encontrou?

Sim

Não

19. Se sim, essa informação que você pesquisou e achou na Bibvirt...

... continha exatamente os dados que você estava procurando.

... continha dados muito sofisticados.

... continha dados muito simples.

20. Se ela não era adequada as suas necessidades, explique por quê.

21. Qual foi o caminho que você fez para localizar a informação que estava procurando?

Ex: Vamos supor que você estivesse procurando informações sobre aves brasileiras.

Você pode ter feito o seguinte caminho: link busca, colocado a palavra-chave "aves brasileiras" e depois clicado no link "banco de imagens - aves do Brasil".

22. Descreva, de maneira sucinta, qual foi a dificuldade que encontrou na busca da informação procurada. 
23. O material que você pesquisou e achou na Bibvirt, seria de fácil acesso em outra fonte de pesquisa, tais como livros, revistas, jornais, Cd-Roms etc.?

$\square$ Sempre

$\square$ Quase sempre

Às vezes

Raramente

Nunca

24. Quando você acha o material de pesquisa, tem facilidade para ler o seu conteúdo?

$\square \operatorname{Sim}$

Não

25. O que você acha que poderíamos fazer para facilitar a localização das informações no acervo?

26. Que partes da Bibvirt você usa/ já usou? (escolha quantos itens quiser)

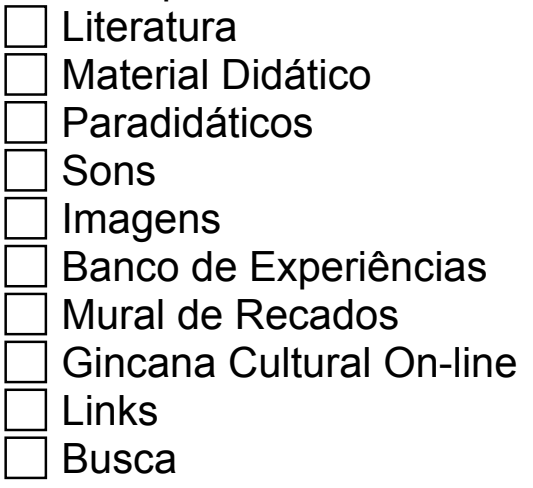

27. Quando você acha o material de pesquisa, tem dificuldade para ler seu conteúdo?

$\square$ Sim

Não

28. Se você tem dificuldade, por quê?

29. Qual informação você gostaria de encontrar na Bibvirt?

30. Como você utiliza os livros existentes na seção de Literatura? (marque quantos itens quiser):

$\square$ Leio na tela do micro.

$\square$ Imprimo direto da Internet

$\square$ Faço download e depois leio na tela do micro.

$\square$ Faço download e depois imprimo

$\square$ Leio em um "palmtop" ou outro micro de mão.

$\square$ Outros: 
31. Marque apenas um item:

$\square$ Costumo ler o livro todo

$\square$ Não costumo ler o livro todo.

32. Qual é a sua área de interesse?

$\square$ Material didático para o Ensino Fundamental I

$\square$ Material didático para o Ensino Fundamental II

Material didático para o Ensino Médio

$\square$ Material didático para o Ensino Superior

$\square$ Material paradidático

$\square$ Material da área de informática

$\square$ Material pedagógico

$\square$ Outros. Quais?

33. Alguma vez você requisitou ajuda da Bibvirt para tirar dúvidas?

$\square$ Sim

$\square$ Não

34. Se sim, conseguiu resolvê-la?

$\square$ Sim

35. Se sim, esta informação acrescentou algo novo nos seus conhecimentos de informática?

$\square$ Sim

$\square$ Não

36. O que mais você gostaria que tivesse no site da Bibvirt?

37. Se você já utilizou com sucesso a Bibvirt para pesquisa escolar ou como apoio em atividades educacionais (ensino ou aprendizagem), por favor, nos conte brevemente, mas com alguns detalhes, como foi seu uso.

Exemplo: "usei a Vozoteca para ilustrar, com os discursos em áudio, uma aula de História em que eu ensinei sobre o governo de Getúlio Vargas para alunos da $2^{\mathrm{a}}$ série do Ensino Médio. A receptividade por parte dos alunos foi..."

Se você escreveu um relato acima, por favor, preencha o seu e-mail. O seu email não será divulgado. Precisamos dele para podermos usar o seu relato para fins acadêmicos.

E-mail:

Sua opinião é muito importante para nós. Se você tem comentários ou sugestões de como podemos melhorar a Bibvirt, escreva-nos!

Obrigado pela colaboração! 


\section{Anexo 5}

\section{A Equipe da Biblioteca Virtual}

A equipe da Bibvirt é composta atualmente por seis pessoas - contamos ainda com a ajuda de vários colegas (http://www.bibvirt.futuro.usp.br/nos/equipe velha.html ), que já trabalharam conosco e daqueles que foram os responsáveis (http://www.bibvirt.futuro.usp.br/nos/pioneiros.html) pela implementação inicial da Bibvirt e claro, de inúmeros voluntários (http://www.bibvirt.futuro.usp.br/creditos/voluntarios/galeria.html)

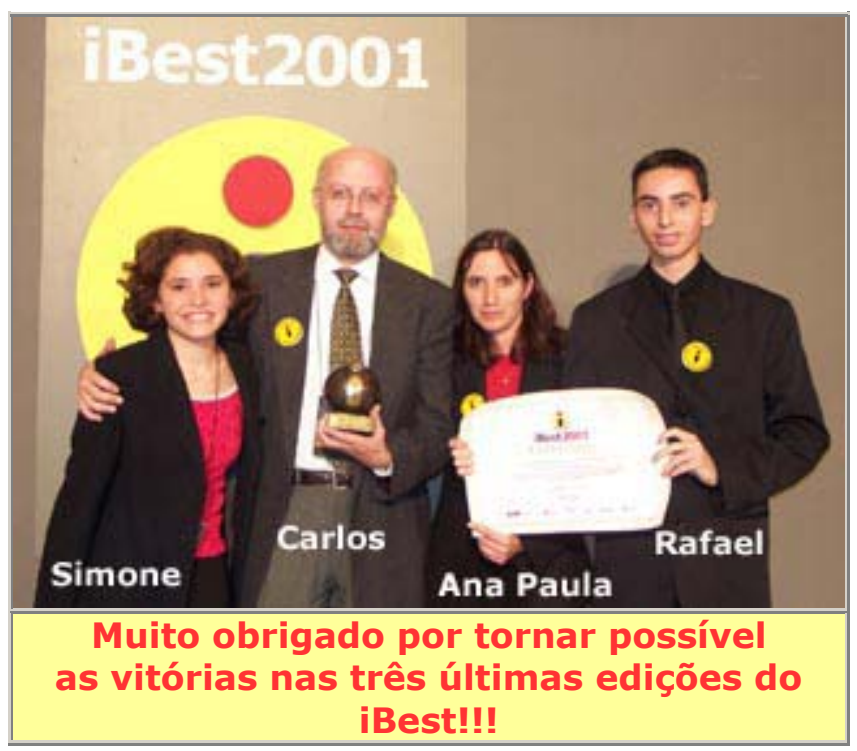

Ana Paula Leite de Camargo formada em Publicidade e Propaganda. Faz a manutenção das páginas do site, ajuda a elaborar a "BVNovas", é responsável pelos projetos "Datas Comemorativas", "CD Nature" e pela seção de "Links". Responde também os e-mails enviados à Bibvirt. Ana Paula já integrou também a equipe do Museu da Pessoa.

Carlos Seabra é editor e produtor de conteúdos de multimídia e Internet, consultor de tecnologia educacional, autor de diversos artigos, softwares educacionais, jogos de entretenimento, sites culturais, educacionais e corporativos, além de coordenar a equipe Bibvirt.

Dirlene P. Oliveira cursa Biblioteconomia na ECA - USP. É responsável pela inserção de novas obras literárias, catalogação e indexação do material da Bibvirt, além de ajudar na manutenção e desenvolvimento do acervo.

Heloísa Hernandez do Nascimento cursa Editoração na Escola de Comunicações e Artes da USP. Ela é responsável pela revisão das obras de literatura e também por todos os textos sobre o site (produção e revisão), ainda atende aos voluntários e aos usuários que enviam mensagens para a BibVirt. 
Rodrigo Fernandes de Almeida cursa Matemática no Instituto de Matemática e Estatística da USP. Ele é o responsável pela implantação e gerenciamento do nosso novo banco de dados e também de todos os outros recursos do site que envolvem programação.

Simone Freitas cursa Biblioteconomia na Escola de Comunicação e Artes da USP. Além de ser nossa especialista em assuntos ligados à Ciência da Informação, Simone é ainda a encarregada pelo controle de voluntários, mural de recados, livro de visitas e livro de receitas.

\section{Antigos membros da equipe da Biblioteca Virtual}

Rafael Durbano Lobato terminou há pouco o Ensino Médio, agora está estudando para ingressar na faculdade no curso de Ciências da Computação.

Sílvia Carvalho Ricardo é formada em Administração pela FGV e tem uma larga experiência no mercado editorial, conquistada em empresas como a Editora Moderna e a Harbra. Passou a fazer parte da equipe como coordenadora do projeto em dezembro de 1999, ajudando nas duras tarefas de captação de patrocínios e novos materiais para o acervo da Bibvirt. Hoje Sílvia trabalha na editoração do Anglo Vestibulares.

\section{Primeiros membros da equipe da Biblioteca Virtual}

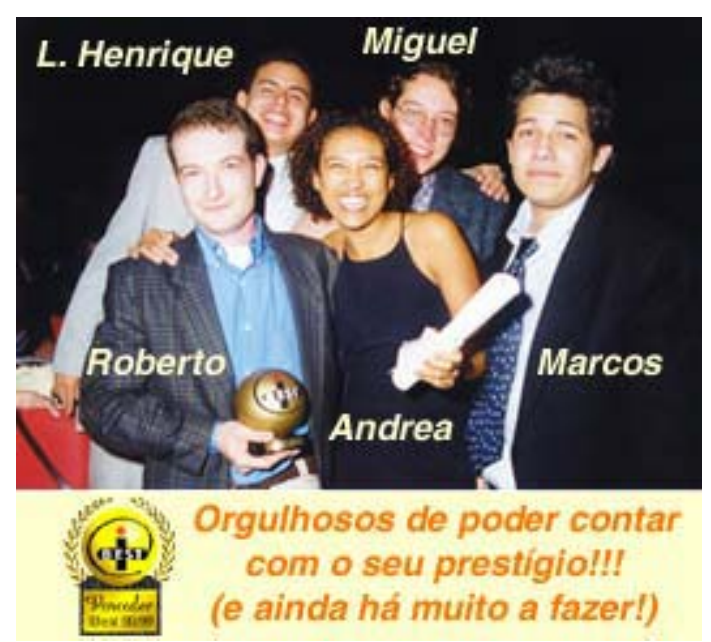

Andréa Gonçalves é estudante de Biblioteconomia na Escola de Comunicação e Artes da USP. Como "membro sênior" da equipe, foi responsável pela estrutura geral do site, buscando novos materiais para o acervo e pesquisando maneiras de facilitar a busca de informação. Hoje, Andréa integra a equipe da USP Online.

Luis Henrique Cassis Fagundes tem 20 anos, dos quais "apenas" 11 são de experiência em programação. Não por acaso, é estudante do curso de Matemática no Instituto de Matemática e Estatística da USP. Nosso "polidor de bytes" deu suporte técnico necessário para que várias de nossas idéias se transformassem em realidade. Atualmente está em Portugal trabalhando para o SAPO - Portugal Online - www.sapo.pt. 
Marcos Brias está cursando Desenho Industrial na FAAP. Entre uma e outra aventura de sua existência, fez às vezes de "diretor de arte", sendo responsável pela maior parte das imagens e grafismos do site.

Miguel Said Vieira fez o curso de Editoração na Escola de Comunicação e Artes da USP. Também Técnico em Processamento de Dados pela Unicamp, durante dois anos trabalhou na Bibvirt. Durante esse período, introduziu o trabalho voluntário, foi webmaster, respondeu algumas milhares de mensagens; acima de tudo, segundo ele, aprendeu muito - especialmente com seus erros. Atualmente, trabalha como freelancer na área de editoração.

Roberto Kirschbaum formado em Administração de Empresas pela Fundação Getúlio Vargas/SP, é ex-coordenador da Biblioteca Virtual, "fundador e membro honorário aposentado", como se auto-define. Foi da mente e do trabalho deste cidadão que surgiram muitas das realizações a que se deve o êxito deste site. Agora, está fazendo outros sites de sucesso junto à One2one Interativa. Fale com ele pelo email <betoinabox@yahoo.com>.

\section{Galeria de Voluntários}

\section{Obras em digitação}

\begin{tabular}{|c|c|c|c|}
\hline Obra & Autor & Nome & $\begin{array}{l}\text { Cidade - } \\
\text { Estado }\end{array}$ \\
\hline O Arco de Sant'ana & Almeida Garret & \multicolumn{2}{|c|}{ incógnito a pedido do voluntário } \\
\hline Alfarrábios & José de Alencar & $\begin{array}{c}\text { Pedro Henrique da Cruz } \\
\text { Matias }\end{array}$ & São Paulo - SP \\
\hline Amor de Perdição & $\begin{array}{c}\text { Camilo Castelo } \\
\text { Branco }\end{array}$ & Fernanda Jakomulsky & São Paulo - SP \\
\hline Amor de Salvação & $\begin{array}{c}\text { Camilo Castelo } \\
\text { Branco }\end{array}$ & $\begin{array}{l}\text { Edilene de Fatima } \\
\text { Fernandes Glauzer }\end{array}$ & Sorocaba - SP \\
\hline Amor e Pátria & $\begin{array}{l}\text { Joaquim Manuel de } \\
\text { Macedo }\end{array}$ & $\begin{array}{l}\text { Claudia de Moura Leite } \\
\text { Ribeiro }\end{array}$ & São Paulo - SP \\
\hline $\begin{array}{l}\text { Os Amores (poemas } \\
\text { escolhidos) }\end{array}$ & Bocage & Ângela du Bocage Alves & Rio de Janeiro - RJ \\
\hline Amores do Diabo & $\begin{array}{c}\text { Camilo Castelo } \\
\text { Branco }\end{array}$ & $\begin{array}{c}\text { Renata Silva Chagas } \\
\text { Larangeira }\end{array}$ & Rio de Janeiro - RJ \\
\hline Auto da Barca do Purgatório & Gil Vicente & $\begin{array}{c}\text { Eduardo Miele Dal Secco } \\
\text { Junior }\end{array}$ & Batatais - SP \\
\hline Auto da Lusitânia & Gil Vicente & Gisele Braga da Silveira & Rio de Janeiro - RJ \\
\hline O Bobo & Alexandre Herculano & Valéria Mello & Batatais - SP \\
\hline Os Brilhantes do Brasileiro & $\begin{array}{c}\text { Camilo Castelo } \\
\text { Branco }\end{array}$ & $\begin{array}{c}\text { Teresa Cristina Caetano } \\
\text { da Silva }\end{array}$ & $\begin{array}{l}\text { Santana do } \\
\text { Parnaíba - SP }\end{array}$ \\
\hline A Bruxa de Monte Córdova & $\begin{array}{c}\text { Camilo Castelo } \\
\text { Branco }\end{array}$ & $\begin{array}{c}\text { Alvaro Arnoldo Maia } \\
\text { Peres }\end{array}$ & Ribeirão Preto - SP \\
\hline $\begin{array}{l}\text { A Cachoeira de Paulo } \\
\text { Afonso }\end{array}$ & Castro Alves & Jackson Figueiredo & $\begin{array}{l}\text { Belo Horizonte - } \\
\text { MG }\end{array}$ \\
\hline O Califa da Rua do Sabão & Artur Azevedo & Sérgio Luiz Simonato & Campinas - SP \\
\hline
\end{tabular}




\begin{tabular}{|c|c|c|c|}
\hline Camões e o Jaú & Casimiro de Abreu & Fernanda Duarte & Rio de Janeiro - RJ \\
\hline Canaã & Graça Aranha & Fábio Kiyoshi Sakata & São Paulo - SP \\
\hline Cancioneiro Guasca & $\begin{array}{c}\text { José Simões Lopes } \\
\text { Neto }\end{array}$ & $\begin{array}{l}\text { Luciene dos Santos } \\
\text { Batista Flores }\end{array}$ & Porto Alegre - RS \\
\hline Cantos e Recantos & Gonçalves Dias & Claudia Vieira de Souza & $\begin{array}{l}\text { Belo Horizonte - } \\
\text { MG }\end{array}$ \\
\hline A Capital & Eça de Queirós & Carolina Mori & Osasco - SP \\
\hline China - estudos e traduções & Camilo Pessanha & Fábio Kiyoshi Sakata & São Paulo - SP \\
\hline O Conde de Abranhos & Eça de Queirós & Luisa Nogueira Chaves & Lavras - MG \\
\hline Contos & Eça de Queirós & $\begin{array}{c}\text { Ana Maria Neves Wady } \\
\text { Debes }\end{array}$ & Curitiba - PR \\
\hline Contos Escolhidos & Artur Azevedo & Vítor C. Dassié & Rio de Janeiro - RJ \\
\hline Contos sem Data & Machado de Assis & Andresa Scucuglia Silva & Santos - SP \\
\hline Ao Correr da Pena & José de Alencar & $\begin{array}{l}\text { Marciana Maria Muniz } \\
\text { Guedes }\end{array}$ & São Paulo - SP \\
\hline Crônicas Escolhidas & Lima Barreto & $\begin{array}{l}\text { Luciane Madrid Cesar } \\
\text { Rezende }\end{array}$ & Varginha - MG \\
\hline $\begin{array}{l}\text { Cultura e Opulência do } \\
\text { Brasil }\end{array}$ & André João Antonil & Evaldo Nunes de Almeida & Araruama - RJ \\
\hline A Dama Pé de Cabra & Alexandre Herculano & $\begin{array}{c}\text { Patrícia Margarete Costa } \\
\text { Vegh }\end{array}$ & São Paulo - SP \\
\hline \begin{tabular}{|l}
$\begin{array}{l}\text { Diálogos das Grandezas do } \\
\text { Brasil }\end{array}$ \\
\end{tabular} & $\begin{array}{c}\text { Ambrósio Fernandes } \\
\text { Brandão }\end{array}$ & Crisoston Terto & $\begin{array}{l}\text { Belo Horizonte - } \\
\text { MG }\end{array}$ \\
\hline A Divina Pastora & $\begin{array}{l}\text { José Antonio do } \\
\text { Vale Caldre e Fião }\end{array}$ & Eduardo Boff Cruz & Porto Alegre - RS \\
\hline Os Dois Burros e o Mono & $\begin{array}{l}\text { Manuel Maria du } \\
\text { Bocage }\end{array}$ & Simone Rosales & Porto Alegre - RS \\
\hline Os Dois Gatos & $\begin{array}{l}\text { Manuel Maria du } \\
\text { Bocage }\end{array}$ & Simone Rosales & Porto Alegre - RS \\
\hline $\begin{array}{l}\text { Os Dous, ou O Inglês } \\
\text { Maquinista }\end{array}$ & Martins Pena & \multicolumn{2}{|c|}{ incógnito a pedido do voluntário } \\
\hline O Ermitão de Muquém & Bernardo Guimarães & Dayse Mendes & Curitiba - Paraná \\
\hline Escritos Avulsos I & Machado de Assis & Flavia Jobstraibizer & São Paulo - SP \\
\hline O Esqueleto & $\begin{array}{c}\text { Camilo Castelo } \\
\text { Branco }\end{array}$ & Jean-Luc Dubas Matoury & Guiana Francesa \\
\hline Uma Família Inglesa & Júlio Dinis & Luana Vita & Salvador - BA \\
\hline $\begin{array}{l}\text { Os Fidalgos da Casa } \\
\text { Mourisca }\end{array}$ & Júlio Dinis & $\begin{array}{c}\text { Paulo Luiz de Lima } \\
\text { Martins }\end{array}$ & Brasília - DF \\
\hline Frei Luís de Souza & Almeida Garret & Aparecido Donizete Rossi & São Paulo - SP \\
\hline O Garimpeiro & Bernardo Guimarães & Iolanda Santos da Silva & Fortaleza - CE \\
\hline O Gaúcho & José de Alencar & Silvia Ernestina Soares & São Paulo - SP \\
\hline A Guerra dos Mascates & José de Alencar & Karina Santos do Prado & São Paulo - SP \\
\hline Iaiá Garcia & Machado de Assis & Jean-Luc Dubas Matoury & Guiana Francesa \\
\hline A llustre Casa de Ramires & Eça de Queirós & Érica Santiago de Sena & São Paulo - SP \\
\hline $\begin{array}{l}\text { A Imprensa e o Dever da } \\
\text { Verdade }\end{array}$ & Rui Barbosa & Priscila Couto Vieira & Guaratinguetá - SP \\
\hline Ingleses na costa & França Júnior & Claudia de Moura Leite & São Paulo - SP \\
\hline
\end{tabular}




\begin{tabular}{|c|c|c|c|}
\hline & & Ribeiro & \\
\hline $\begin{array}{l}\text { O Judas em Sábado de } \\
\text { Aleluia }\end{array}$ & Martins Pena & Ana Luiza França & São Paulo - SP \\
\hline Uma Lágrima de Mulher & Aluísio Azevedo & José Aleixo dos Reis & $\begin{array}{l}\text { Belo Horizonte - } \\
\text { MG }\end{array}$ \\
\hline Leonor de Mendonça & Gonçalves Dias & Angélica Perez & São Paulo - SP \\
\hline Luxo e Vaidade & $\begin{array}{l}\text { Joaquim Manuel de } \\
\text { Macedo }\end{array}$ & $\begin{array}{c}\text { Claudia de Moura Leite } \\
\text { Ribeiro }\end{array}$ & São Paulo - SP \\
\hline À Margem da Geografia & Euclides da Cunha & \begin{tabular}{|c|} 
Lílian Ribeiro Pondé de \\
Rocha
\end{tabular} & Salvador - BA \\
\hline O Matuto & Franklin Távora & \multicolumn{2}{|c|}{ incógnito a pedido do voluntário } \\
\hline As Minas de Prata & José de Alencar & Cláudia Regina Lobo & Rio de Janeiro - RJ \\
\hline $\begin{array}{l}\text { O Mistério da Estrada de } \\
\text { Sintra }\end{array}$ & $\begin{array}{l}\text { Eça de Queirós e } \\
\text { Ramalho Ortigão }\end{array}$ & \begin{tabular}{|c|} 
Marcos Antonio Ferreira \\
de Souza
\end{tabular} & $\begin{array}{c}\text { Itaquaquecetuba - } \\
\text { SP }\end{array}$ \\
\hline O Moço Loiro & $\begin{array}{c}\text { Joaquim Manuel de } \\
\text { Macedo }\end{array}$ & $\begin{array}{c}\text { Paulo Sérgio Costa } \\
\text { Borges }\end{array}$ & Maceió - Alagoas \\
\hline A Moreninha & $\begin{array}{c}\text { Joaquim Manuel de } \\
\text { Macedo }\end{array}$ & $\begin{array}{l}\text { Bernadete Rocha } \\
\text { Espinoza }\end{array}$ & Caraguatatuba - SP \\
\hline A Morgadinha dos Canaviais & Júlio Dinis & Ítalo Paulo Corbani & Jacareí - SP \\
\hline $\begin{array}{l}\text { O Namorador ou a Noite de } \\
\text { São João }\end{array}$ & Martins Pena & Adailton Alves & São Paulo - SP \\
\hline Os Noivos & Artur Azevedo & Sérgio Luiz Simonato & Campinas - SP \\
\hline Numa e Ninfa & Lima Barreto & Sérgio Luiz Simonato & Campinas - SP \\
\hline \begin{tabular}{|l|} 
Parnaso Bocagiano \\
(Collecção integral e não- \\
expurgada das Poesias \\
Eróticas, Burlescas e \\
Satyricas) \\
\end{tabular} & Bocage & \multicolumn{2}{|c|}{ incógnito a pedido do voluntário } \\
\hline Poemas & $\begin{array}{c}\text { Antônio Gonçalves } \\
\text { Dias }\end{array}$ & Angela Soares & $\begin{array}{l}\text { São José dos } \\
\text { Campos - SP }\end{array}$ \\
\hline Poemas & Fagundes Varela & \begin{tabular}{|c|} 
Jefferson Fernandes do \\
Vale
\end{tabular} & Suzano - SP \\
\hline Poesias & Olavo Bilac & Maíra Malosso & Campinas - SP \\
\hline Poesias & $\begin{array}{l}\text { Mário de Sá- } \\
\text { Carneiro }\end{array}$ & $\begin{array}{c}\text { Valdinei Soares de } \\
\text { Oliveira }\end{array}$ & Curitiba - PR \\
\hline $\begin{array}{l}\text { Poesia de Todos os } \\
\text { Tempos: Antero de Quental } \\
\text { - Antologia }\end{array}$ & Antero de Quental & $\begin{array}{l}\text { Maria Fernanda Amado } \\
\text { Morillo de Andrade }\end{array}$ & São Paulo - SP \\
\hline Poesias Completas & Cesário Verde & Emerson Kamiya & São Paulo - SP \\
\hline $\begin{array}{l}\text { Uma Praga Rogada nas } \\
\text { Escadarias da Fôrca }\end{array}$ & $\begin{array}{c}\text { Camilo Castelo } \\
\text { Branco } \\
\end{array}$ & Simone Rosales & Porto Alegre - RS \\
\hline As Primaveras & Casimiro de Abreu & Raquel Sallaberry Brião & São Paulo - SP \\
\hline O Primo Basílio & Eça de Queirós & $\begin{array}{l}\text { Flávia Fernanda } \\
\text { Francisco Machado }\end{array}$ & Vinhedo - SP \\
\hline A Queda d'um Anjo & $\begin{array}{l}\text { Camilo Castelo } \\
\text { Branco }\end{array}$ & Barbara Martins Teixeira & São Paulo - SP \\
\hline Quem tem Farelos? & Gil Vicente & Paulo David Benson & Caçapava - SP \\
\hline Ressurreição & Machado de Assis & Ana Célia Moura & - \\
\hline O Seminarista & Bernardo Guimarães & Marcelo Müller & São Paulo - SP \\
\hline
\end{tabular}




\begin{tabular}{|l|c|c|c|}
\hline O Sertanejo & José de Alencar & $\begin{array}{c}\text { Gleidy Aparecida Lima } \\
\text { Milani }\end{array}$ & Londrina - PR \\
\hline Sonetos e Outros Poemas & $\begin{array}{c}\text { Manuel Maria du } \\
\text { Bocage }\end{array}$ & Antonio Luiz Lopes & Guarulhos - SP \\
\hline Terpsicore (conto) & Machado de Assis & Luciene Monteiro & Belém - PA \\
\hline Uma Tragédia no Amazonas & Raul Pompéia & $\begin{array}{c}\text { Rafael Marques dos } \\
\text { Santos }\end{array}$ & Pouso Alegre - MG \\
\hline O Tronco do Ipê & José de Alencar & $\begin{array}{c}\text { Samantha Sobral de } \\
\text { Freitas Neves }\end{array}$ & Rio de Janeiro - RJ \\
\hline Ubirajara & José de Alencar & Adriano Alves da Silva & Fortaleza - CE \\
\hline O Uraguai & Basílio da Gama & Alice Dauber & São Leopoldo - RS \\
\hline A Viúva do Enforcado & $\begin{array}{c}\text { Camilo Castelo } \\
\text { Branco }\end{array}$ & Jean-Luc Dubas Matoury & Guiana Francesa \\
\hline \hline
\end{tabular}

\section{Obras já digitadas}

\begin{tabular}{|c|c|c|c|}
\hline Obra & Autor & Nome & $\begin{array}{l}\text { Cidade - } \\
\text { Estado }\end{array}$ \\
\hline Abel e Helena & Artur Azevedo & Sérgio Luiz Simonato & Campinas - SP \\
\hline Alves \& Cia. & Eça de Queirós & $\begin{array}{c}\text { Marciana Maria Muniz } \\
\text { Guedes }\end{array}$ & São Paulo - SP \\
\hline \begin{tabular}{|l|} 
Arras por Foro de \\
Espanha \\
\end{tabular} & Alexandre Herculano & José Antônio Assis & União da Vitória - PR \\
\hline Um Assovio & $\begin{array}{c}\text { Qorpo Santo (José } \\
\text { Joaquim de Campos } \\
\text { Leão) }\end{array}$ & Solange L. S. de Jesus & Curitiba - PR \\
\hline \begin{tabular}{|l} 
Auto de Mofina \\
Mendes \\
\end{tabular} & Gil Vicente & Paulo David Benson & Caçapava - SP \\
\hline O Bispo Negro & Alexandre Herculano & José Antônio Assis & União da Vitória - PR \\
\hline Bom Crioulo & Adolfo Caminha & Sérgio Luiz Simonato & Campinas - SP \\
\hline A Capital Federal & Artur Azevedo & Selma Suely Teixeira & Curitiba - PR \\
\hline A Carne & Júlio Ribeiro & Neucirio Ricardo de Azevedo & \\
\hline \begin{tabular}{|l} 
As Casadas \\
Solteiras \\
\end{tabular} & Martins Pena & Valéria Mello & Batatais - SP \\
\hline \begin{tabular}{|l} 
A Casadinha de \\
Fresco
\end{tabular} & Artur Azevedo & Sérgio Luiz Simonato & Campinas - SP \\
\hline \begin{tabular}{|l} 
Certa Entidade \\
em Busca de \\
Outra \\
\end{tabular} & $\begin{array}{c}\text { Qorpo Santo (José } \\
\text { Joaquim de Campos } \\
\text { Leão) }\end{array}$ & Solange L. S. de Jesus & Curitiba - PR \\
\hline $\begin{array}{l}\text { A Cidade e as } \\
\text { Serras } \\
\end{array}$ & Eça de Queirós & $\begin{array}{l}\text { Marciana Maria Muniz } \\
\text { Guedes }\end{array}$ & São Paulo - SP \\
\hline \begin{tabular}{|l} 
A Confissão de \\
Lúcio \\
\end{tabular} & Mário de Sá-Carneiro & Mauro José da Silva & São Paulo - SP \\
\hline \begin{tabular}{|l|} 
Auto \\
Representado na \\
Festa de São \\
Lourenço \\
\end{tabular} & José de Anchieta & Sérgio Luiz Simonato & Campinas - SP \\
\hline Carolina & Casimiro de Abreu & Fernanda Duarte & Rio de Janeiro - RJ \\
\hline Cartas D'Amor - & Eça de Queirós & Celia Terezinha Zago & Santos - SP \\
\hline
\end{tabular}




\begin{tabular}{|c|c|c|c|}
\hline Feminino & & & \\
\hline Casa de Pensão & Aluísio de Azevedo & \begin{tabular}{|c} 
José Carlos Azeredo (e Nilza \\
Dias F. Azeredo)
\end{tabular} & Foz do Iguaçu - PR \\
\hline $\begin{array}{l}\text { Contos } \\
\text { Gauchescos } \\
\end{array}$ & João Simões Lopes Neto & Luiz Abel Silva & Palhoça - SC \\
\hline \begin{tabular}{|l|} 
Coração, Cabeça \\
e Estômago \\
\end{tabular} & Camilo Castelo Branco & \multicolumn{2}{|c|}{ incógnito a pedido do voluntário } \\
\hline \begin{tabular}{|l} 
Um Credor da \\
Fazenda \\
Nacional \\
\end{tabular} & $\begin{array}{c}\text { Qorpo Santo (José } \\
\text { Joaquim de Campos } \\
\text { Leão) }\end{array}$ & Solange L. S. de Jesus & Curitiba - PR \\
\hline \begin{tabular}{|l} 
O Crime do \\
Padre Amaro \\
\end{tabular} & Eça de Queirós & \multicolumn{2}{|c|}{ incógnito a pedido do voluntário } \\
\hline Crisfal & Cristóvão Falcão & $\begin{array}{l}\text { Francisco de Mesquita } \\
\text { Moreira }\end{array}$ & Rio de Janeiro - RJ \\
\hline $\begin{array}{l}\text { Dona Guidinha } \\
\text { do Poço }\end{array}$ & Manoel de Oliveira Paiva & Valéria Mello & Batatais - SP \\
\hline $\begin{array}{l}\text { Ao Entardecer } \\
\text { (contos vários) } \\
\end{array}$ & Visconde de Taunay & $\begin{array}{c}\text { Maria Isabel Braun Singer } \\
\text { Macha }\end{array}$ & Rio Claro - SP \\
\hline \begin{tabular}{|l} 
Eurico, o \\
Presbítero \\
\end{tabular} & Alexandre Herculano & Paula Regina Cícero Yort & $\begin{array}{l}\text { São Bernardo do } \\
\text { Campo - SP }\end{array}$ \\
\hline$\frac{\text { Feitos de Mem }}{\text { de Sá }}$ & Padre Anchieta & Sérgio Luiz Simonato & Campinas - SP \\
\hline $\begin{array}{l}\text { A Filha de Maria } \\
\text { Angu } \\
\end{array}$ & Artur Azevedo & Sérgio Luiz Simonato & Campinas - SP \\
\hline Flores da Noite & $\begin{array}{l}\text { Lycurgo José Henrique } \\
\text { de Paiva }\end{array}$ & Jorge Alberto Tajra Mayle & Teresina - PI \\
\hline Folhas Caídas & Almeida Garret & Paula Marçal & Lisboa - Portugal \\
\hline $\begin{array}{l}\text { Histórias e } \\
\text { Sonhos }\end{array}$ & Lima Barreto & $\begin{array}{c}\text { Rodrigo Nunes de Oliveira } \\
\text { Cardoso }\end{array}$ & São Paulo - SP \\
\hline $\begin{array}{l}\frac{\text { O Homem que }}{\text { Sabia Javanês e }} \\
\text { Outros Contos } \\
\end{array}$ & Lima Barreto & Rodrigo Souza & Curitiba - PR \\
\hline Os Irmãos das & Martins Pena & Andréa Massamyi Matsunaga & São Paulo - SP \\
\hline A Jóia & Artur Azevedo & Sérgio Luiz Simonato & Campinas - SP \\
\hline $\begin{array}{l}\text { As J óias da } \\
\text { Coroa } \\
\end{array}$ & Raul Pompéia & \multicolumn{2}{|c|}{ incógnito a pedido do voluntário } \\
\hline O Juiz de Paz da & Martins Pena & Ana Luiza França & São Paulo - SP \\
\hline Lendas do Sul & João Simões Lopes Neto & Luiz Abel Silva & Palhoça - SC \\
\hline O Liberato & Artur Azevedo & Sérgio Luiz Simonato & Campinas - SP \\
\hline \begin{tabular}{|l} 
Lira dos Vinte \\
Anos \\
\end{tabular} & Álvares de Azevedo & Marian Nieves & São Paulo - SP \\
\hline \begin{tabular}{|l} 
Livro de uma \\
Sogra \\
\end{tabular} & Aluísio Azevedo & \multicolumn{2}{|c|}{ incógnito a pedido do voluntário } \\
\hline Luzia Homem & Domingos Olympio & Alexandre Galiotto & Florianópolis - SC \\
\hline O Mandarim & Eça de Queirós & $\begin{array}{l}\text { Marciana Maria Muniz } \\
\text { Guedes }\end{array}$ & São Paulo - SP \\
\hline Maria Dusá & Lindolfo Rocha & Valéria Mello & Batatais - SP \\
\hline
\end{tabular}




\begin{tabular}{|c|c|c|c|}
\hline Marília de Dirceu & Tomás Antonio Gonzaga & Sérgio Scuotto & Belo Horizonte - MG \\
\hline$\frac{\text { Mateus e }}{\text { Mateusa }}$ & $\begin{array}{c}\text { Qorpo Santo (José } \\
\text { Joaquim de Campos } \\
\text { Leão) }\end{array}$ & Selma Suely Teixeira & Curitiba - PR \\
\hline Missionário & Inglês de Souza & Luciana Avila Duarte & \\
\hline$\frac{\text { A Morte do }}{\text { Lidador }}$ & Alexandre Herculano & Simone Rosales & Porto Alegre - RS \\
\hline A Normalista & Adolfo Caminha & Sérgio Luiz Simonato & Campinas - SP \\
\hline $\begin{array}{l}\text { Nova Viagem à } \\
\text { Lua }\end{array}$ & Artur Azevedo & Sérgio Luiz Simonato & Campinas - SP \\
\hline O Noviço & Martins Pena & Sérgio Luiz Simonato & Campinas - SP \\
\hline Pedro Gobá & Ezequiel Freire & José Eduardo Oliveira Bruno & São Paulo - SP \\
\hline A Pele do Lobo & Artur Azevedo & Sérgio Luiz Simonato & Campinas - SP \\
\hline Poemas & Alphonsus de Guimarães & Anderson Gama & $\begin{array}{l}\text { São José dos } \\
\text { Campos - SP }\end{array}$ \\
\hline \begin{tabular}{|l} 
Poesias \\
Coligidas \\
\end{tabular} & Castro Alves & Dickson dos Santos Guedes & Laguna - SC \\
\hline Primeiros Cantos & Gonçalves Dias & Lidiane Vogel Sander & Belo Horizonte - MG \\
\hline $\begin{array}{l}\text { O Primo da } \\
\text { Califórnia } \\
\end{array}$ & $\begin{array}{l}\text { Joaquim Manuel de } \\
\text { Macedo }\end{array}$ & Ezequias Eliud & Santa Luzia - MG \\
\hline \begin{tabular}{|l} 
A Princesa dos \\
Cajueiros
\end{tabular} & Artur Azevedo & Sérgio Luiz Simonato & Campinas - SP \\
\hline \begin{tabular}{|l|} 
As Pupilas do \\
Senhor Reitor \\
\end{tabular} & Júlio Dinis & Sérgio Luiz Simonato & Campinas - SP \\
\hline $\begin{array}{l}\text { Quem Casa, } \\
\text { Quer Casa } \\
\end{array}$ & Martins Pena & Valéria Mello & Batatais - SP \\
\hline A Relíquia & Eça de Queirós & Antonio Lisboa Salles Neto & Rio de Janeiro - RJ \\
\hline \begin{tabular}{|l} 
A Retirada da \\
Laguna \\
\end{tabular} & Visconde de Taunay & Evanildo Tadeu R. da Silva & Corumbá - MS \\
\hline \begin{tabular}{|l|} 
O Rio de Janeiro \\
em 1877 \\
\end{tabular} & Artur Azevedo & Sérgio Luiz Simonato & Campinas - SP \\
\hline O Sacrifício & Franklin Távora & Sérgio Luiz Simonato & Campinas - SP \\
\hline Senhora & José de Alencar & Márcia Zubko & Curitiba - PR \\
\hline Sonhos d'Ouro & José de Alencar & $\begin{array}{l}\text { Maria Fernanda Amado } \\
\text { Morillo de Andrade }\end{array}$ & São Paulo - SP \\
\hline \begin{tabular}{|l|} 
O Subterrâneo \\
do Morro do \\
Castelo \\
\end{tabular} & Lima Barreto & \multicolumn{2}{|c|}{ incógnito a pedido do voluntário } \\
\hline Tentação & Adolfo Caminha & Estela de Almeida & Piracicaba - SP \\
\hline Til & José de Alencar & Márcia Zubko & Curitiba - PR \\
\hline Ubirajara & José de Alencar & Caroline Rozendo & \\
\hline \begin{tabular}{|l|} 
Uma V éspera de \\
Reis \\
\end{tabular} & Artur Azevedo & Sérgio Luiz Simonato & Campinas - SP \\
\hline O Velho da Horta & Gil Vicente & Anderson Gama & $\begin{array}{l}\text { São José dos } \\
\text { Campos - SP }\end{array}$ \\
\hline \begin{tabular}{|l} 
Viagens na \\
Minha Terra \\
\end{tabular} & Almeida Garret & Sérgio Luiz Simonato & Campinas - SP \\
\hline
\end{tabular}


Colaborações excepcionais

\begin{tabular}{|c|c|c|}
\hline Colaboração & Nome & $\begin{array}{l}\text { Cidade - } \\
\text { Estado }\end{array}$ \\
\hline $\begin{array}{l}\text { Digitação de artigos de } \underline{A} \text { temática indígena na } \\
\text { escola }\end{array}$ & $\begin{array}{l}\text { Elisangela Matos de } \\
\text { Carvalho }\end{array}$ & Manaus - AM \\
\hline $\begin{array}{l}\text { Digitação de artigos de } A \text { temática indígena na } \\
\text { escola }\end{array}$ & $\begin{array}{l}\text { Marina da Conceição } \\
\text { Almeida }\end{array}$ & Rio de Janeiro - RJ \\
\hline $\begin{array}{l}\text { Digitação de artigos de } \underline{A \text { temática indígena na }} \\
\text { escola }\end{array}$ & Nina Rezende & João Pessoa - PB \\
\hline $\begin{array}{l}\text { Digitação de artigos de } A \text { temática indígena na } \\
\text { escola }\end{array}$ & Sérgio Luiz Simonato & Campinas - SP \\
\hline $\begin{array}{l}\text { Digitação de artigos de } A \text { temática indígena na } \\
\text { escola }\end{array}$ & Ângela Zuim & Brasília - DF \\
\hline $\begin{array}{l}\text { Digitação de discursos de Grandes momentos do } \\
\text { Parlamento brasileiro }\end{array}$ & Alberto Ramos de Oliveira & São Paulo - SP \\
\hline $\begin{array}{l}\text { Digitação de discursos de Grandes momentos do } \\
\text { Parlamento brasileiro }\end{array}$ & $\begin{array}{l}\text { Ana Karyna Gomes de } \\
\text { Almeida }\end{array}$ & Recife - PE \\
\hline $\begin{array}{l}\text { Digitação de discursos de Grandes momentos do } \\
\text { Parlamento brasileiro }\end{array}$ & $\begin{array}{l}\text { Consuelo S. Blanco } \\
\text { Donadelli }\end{array}$ & São Paulo - SP \\
\hline $\begin{array}{l}\text { Digitação de discursos de Grandes momentos do } \\
\text { Parlamento brasileiro }\end{array}$ & $\begin{array}{l}\text { Leandro Torres } \\
\text { Gonçalves }\end{array}$ & Montes Claros - MG \\
\hline $\begin{array}{l}\text { Digitação de discursos de Grandes momentos do } \\
\text { Parlamento brasileiro }\end{array}$ & $\begin{array}{l}\text { Paulo Roberto Braga } \\
\text { Júnior }\end{array}$ & Jacareí - SP \\
\hline $\begin{array}{l}\text { Digitação de discursos de Grandes momentos do } \\
\text { Parlamento brasileiro }\end{array}$ & $\begin{array}{l}\text { Regina Conceição Cecílio } \\
\text { de Oliveira }\end{array}$ & São Paulo - SP \\
\hline $\begin{array}{l}\text { Digitação de discursos de Grandes momentos do } \\
\text { Parlamento brasileiro }\end{array}$ & Tais Bilheiro Carvalho & Juiz de Fora - MG \\
\hline Digitação do livro Aves no campus & Mauricio Campiolo & Cuiabá - MT \\
\hline Digitação do livro Aves no campus & $\begin{array}{l}\text { Regina Luiza de Freitas } \\
\text { Vieira }\end{array}$ & Belo Horizonte - MG \\
\hline Normalização de obras digitalizadas via OCR & $\begin{array}{l}\text { Jorge Miguel Acosta } \\
\text { Soares }\end{array}$ & São Paulo - SP \\
\hline Resenha sobre Monteiro Lobato & Esther Rosado & \\
\hline Tradução e digitação de A odisséia - Homero & Airton Motta & Londres, Inglaterra \\
\hline $\begin{array}{l}\text { Tradução e digitação de Manifesto do } \\
\text { Surrealismo - André Breton }\end{array}$ & Lázaro Curvêlo Chaves & $\begin{array}{l}\text { São José do Rio } \\
\text { Pardo - SP }\end{array}$ \\
\hline
\end{tabular}

